\title{
Removal or storage of environmental pollutants and alternative fuel sources with inorganic adsorbents via host-guest encapsulation
}

\author{
Alisha J. Cramer, ${ }^{1}$ Jacqueline M. Cole ${ }^{1,2,3,4, *}$ \\ ${ }^{1}$ Cavendish Laboratory, Department of Physics, University of Cambridge, J. J. Thomson Avenue, Cambridge, CB3 OHE, UK \\ 2 ISIS Neutron and Muon Source, Rutherford Appleton Laboratory, Harwell Science and Innovation Campus, Didcot, \\ Oxfordshire, OX11 0QX, UK \\ ${ }^{3}$ Department of Chemical Engineering and Biotechnology, University of Cambridge, Philippa Fawcett Drive, Cambridge, CB3 \\ OAS, UK.
}

${ }^{4}$ Argonne National Laboratory, 9700 S. Cass Avenue, Argonne, IL 60439, USA

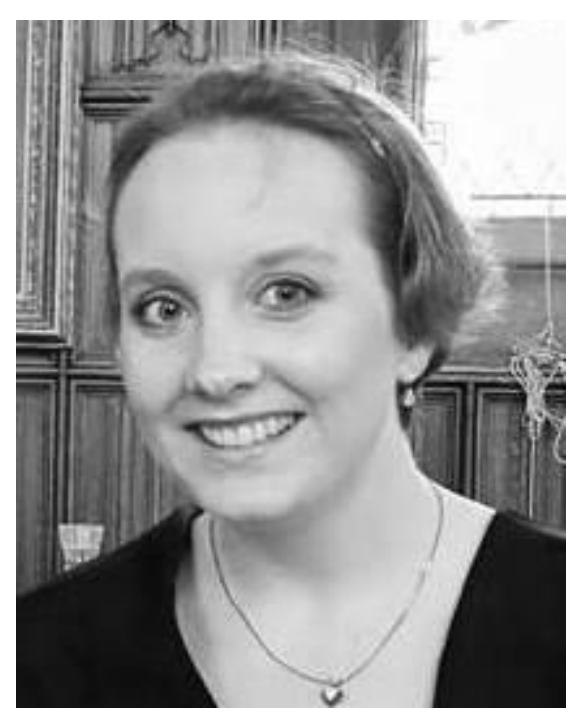

Alisha J. Cramer is currently pursuing her PhD in physics with the Molecular Engineering group at the Cavendish Laboratory, University of Cambridge, under the supervision of Jacqueline M. Cole. Prior to this, she earned her BS from the State University of New York at Stony Brook as a double major in astronomy and physics, with a minor in international studies. She was further awarded an MSc in astrophysics from the University College London. Her primary research interest is the encapsulation of small molecules and ions within three-dimensional inorganic framework structures.

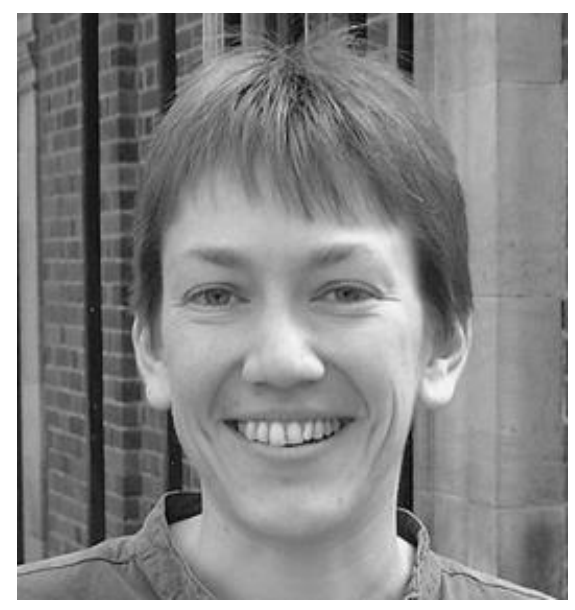

Jacqueline Cole is Head of Molecular Engineering at the University of Cambridge, a joint initiative between the Departments of Physics and Chemical Engineering and Biotechnology, in partnership with STFC Rutherford Appleton Laboratory. Jacqui designs new materials for energy and environmental applications. She holds the 1851 Royal Commission 2014 Fellowship in Design. Other professional recognition includes: Fulbright Award (2013-4); Royal Society University Research Fellowship (2001-11); Royal Society of Chemistry SAC Silver Medal (2009); Royal Society Brian Mercer Feasibility Award (2007); Franco-British Science prize (2006); Junior and Senior Research Fellowships, St Catharine's College, Cambridge (1999-2009); British Crystallographic Association Chemical Crystallography Prize (2000). 


\begin{abstract}
The ever-increasing demands of the modern world continue to place substantial strain on the environment. To help alleviate the damage done to the natural world, the encapsulation of small molecules or ions (guests) into porous inorganic structural frameworks (hosts) provides a potential remedy for some of the environmental concerns facing us today. These concerns include the removal of harmful pollutants from water or air, the safe entrapment of nuclear waste materials, or the purification and storage of small molecules that act as alternative fuel sources. We review the trends in using inorganic materials as host media for the removal or storage of various wastes and alternative fuels. We cover the treatment of water contaminated with dyes or heavy metals, air pollution alleviation via $\mathrm{CO}_{2}, \mathrm{SO}_{x}, \mathrm{NO}_{x}$, and volatile organic compound containment, nuclear waste immobilization, and storage for $\mathrm{H}_{2}$ and methane as alternative fuels.
\end{abstract}

\title{
1. Introduction
}

The trajectory of global industrial development has a profound impact on the planet we inhabit. Virtually all human activity, ranging from domestic care, to consuming goods and services, right through to travel and mobility exert a (usually detrimental) influence on the natural environment. Much research has gone into dampening the negative impact of the way that modern life is having on our precious planetary resources. Nevertheless, it is hardly debatable that more work is required in this area, especially given the related threat that climate change continues to pose a looming danger to our future civilization.

The ever-increasing demand of modern society for energy, goods, and services leads to increased levels of material waste and undesirable byproducts arising from the production of energy from non-renewable sources. Attempts to contain, recover, or reuse waste materials have been manifold. Processes to control or eliminate waste products from varying industrial sources include photodegradation,,$^{1,2}$ oxidation, ${ }^{1,3,4}$ precipitation, ${ }^{3,5,6}$ condensation,,$^{4,7}$ cryogenic distillation, ${ }^{8,9}$ membrane separation, ${ }^{3-5,7,9}$ catalytic reduction, ${ }^{10}$ evaporation, ion exchange, ${ }^{3,5,11}$ and adsorption. ${ }^{3-5,7-9}$ In the context of alternative fuel production, further challenges arise with respect to the purification and storage of small, usually gaseous molecules under ambient conditions, which may require high-pressure or cryogenic containment (e.g. $\mathrm{H}_{2}$ ), or extensive filtration, which is required for the production of methane $\left(\mathrm{CH}_{4}\right)$ from biogas. ${ }^{12-15}$ Even though these protocols somewhat ameliorate the negative impact on the environment, many of these processes still need to be optimized. Common shortcomings in these processes include high costs, poor efficiency, the inability to meet the demands of a removal process, such as decreased efficiency at elevated temperatures, ${ }^{7,15,16}$ or the safe storage of materials such as nuclear waste. ${ }^{17-20}$

An attractive prospective solution to many of these issues is molecular or ionic encapsulation, i.e., the enclosure of a guest molecule or ion within a host material that comprises a porous structural framework (Fig. 1). The inclusion of the guest material can be achieved via adsorption into a porous host network, or through fabrication routes that embed the guest into the host medium in a concerted fashion. While the former method may provide a reversible means of inclusion, the latter represents a more permanent form of entrapment. The environmental management of a range of pollutants and alternative fuel sources may benefit from encapsulation, whether in the form of trapping of hazardous materials, or by providing storage options for the purposes of subsequent practical use. 


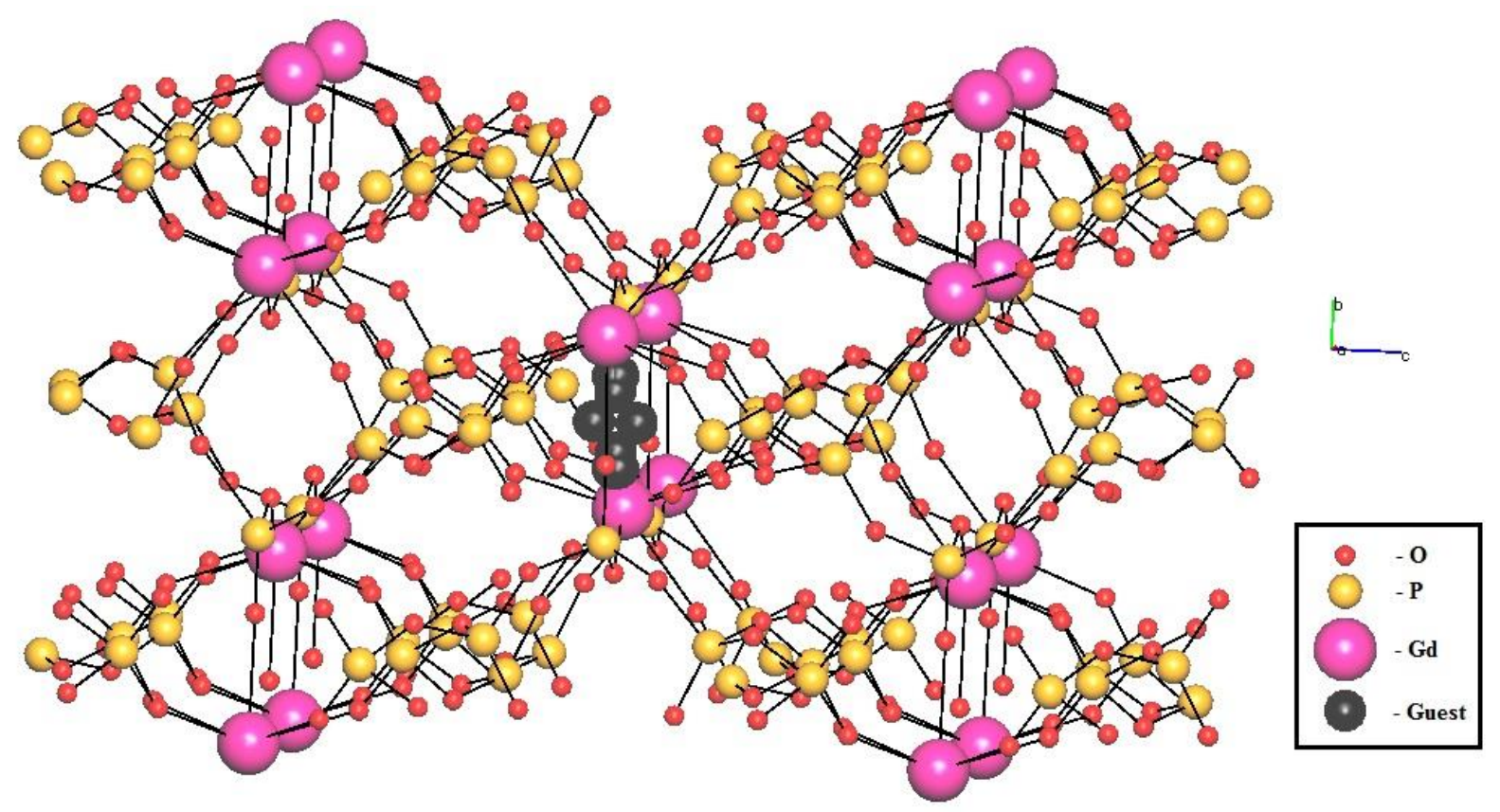

Figure 1. A representative example for the encapsulation of a hypothetical guest (black) within the crystalline structure of $\mathrm{GdP}_{5} \mathrm{O}_{14}$.

Many previous reviews have covered aspects of encapsulation for environmental purposes, most of which focus on one of two basic formats: materials or techniques for specific application s. For water treatment, for instance, reviews cover materials 3 and methods ${ }^{1}$ for the removal of dyes, as well as various classes of materials for the removal of heavy metals. ${ }^{5,6,21-23}$ In general, these reviews mostly survey the challenges of cost that are associated with the treatment of water. In the context of pollution control, techniques have been reviewed for the removal of volatile organic compounds (VOCs) from polluted air, ${ }^{4}$ adsorbent materials for the trapping of VOCs from air, ${ }^{24,25}$ the alleviation of $\mathrm{CO}_{2}$ from flue gas, ${ }^{9,26}$ the removal of $\mathrm{SO}_{x} / \mathrm{NO}_{x}$ from flue gas, ${ }^{10,27}$ or separation of gases ${ }^{8,28}$; here, the challenges of high-temperature encapsulation dominate investigations. Reviews pertaining to alternative fuel sources discuss technologies for biogas purification ${ }^{7,29}$ and hydrogen storage, ${ }^{16}$ materials for hydrogen storage ${ }^{12,14,15,30-32}$ and natural gas purification, ${ }^{8}$ as well as adsorbents investigated in the context of fuel technologies.13,33 Reviews on the immobilization of nuclear waste focus predominantly on materials and design, ${ }^{19,34-39}$ radiation effects, ${ }^{40,41}$ and general disposal. ${ }^{17,42-44}$

In this review, we present an overview of the use of inorganic materials that have been explored to act as host media for the encapsulation of a variety of environmentally important materials. The use of such materials will be discussed in the context of waste water decontamination, encapsulation techniques for the treatment of water, the control of air pollution, nuclear waste management, and the purification and storage of alternative energy fuel sources. It should be noted that while certain carbon-based materials, such as carbon nanotubes, activated carbons, and graphite, among others, are considered 'inorganic,' in the context of this review, 'inorganic' refers to non-carbon-based materials. The consideration of carbon-based inorganic materials would constitute an extensive study within their own right.

\section{The removal of pollutants from wastewater}


Industrial wastewater, sewage, or runoff after rainfall may contain detrimental additives in concentrations that make them unsuitable for human consumption. In many cases, such wastewater may require decontamination before it can be returned safely into the aquatic ecosystem. A multitude of methods based on physical, chemical, and biological purification have been investigated for the removal of contaminants from water. In general, adsorption seems to be the most efficient and cost effective method for the removal of pollutants from wastewater. ${ }^{45}$ Activated carbon is the most widely used for the adsorption of water pollutants, ${ }^{46}$ even though it is relatively expensive and requires subsequent regeneration.

2.1 The removal of dyes from wastewater. A major wastewater contaminant is dyes that originate from textile, paint, ink, and paper industries, as well as from consumer products such as cosmetics, plastics, medicines, and food additives. An estimated > 10,000 tons of dyes per year are produced worldwide, ${ }^{1}$ and for certain types of dyes, the estimated discharge into the environment is as high as 50\%. ${ }^{47}$ Moreover, many dyes are toxic, carcinogenic, or mutagenic. ${ }^{47-57}$ Their colored nature may also affect gas solubility in water and inhibit the passage of light through water, which can affect aquatic life by inhibiting necessary photoinitiated chemical reactions. $47,48,53,56,58,59$

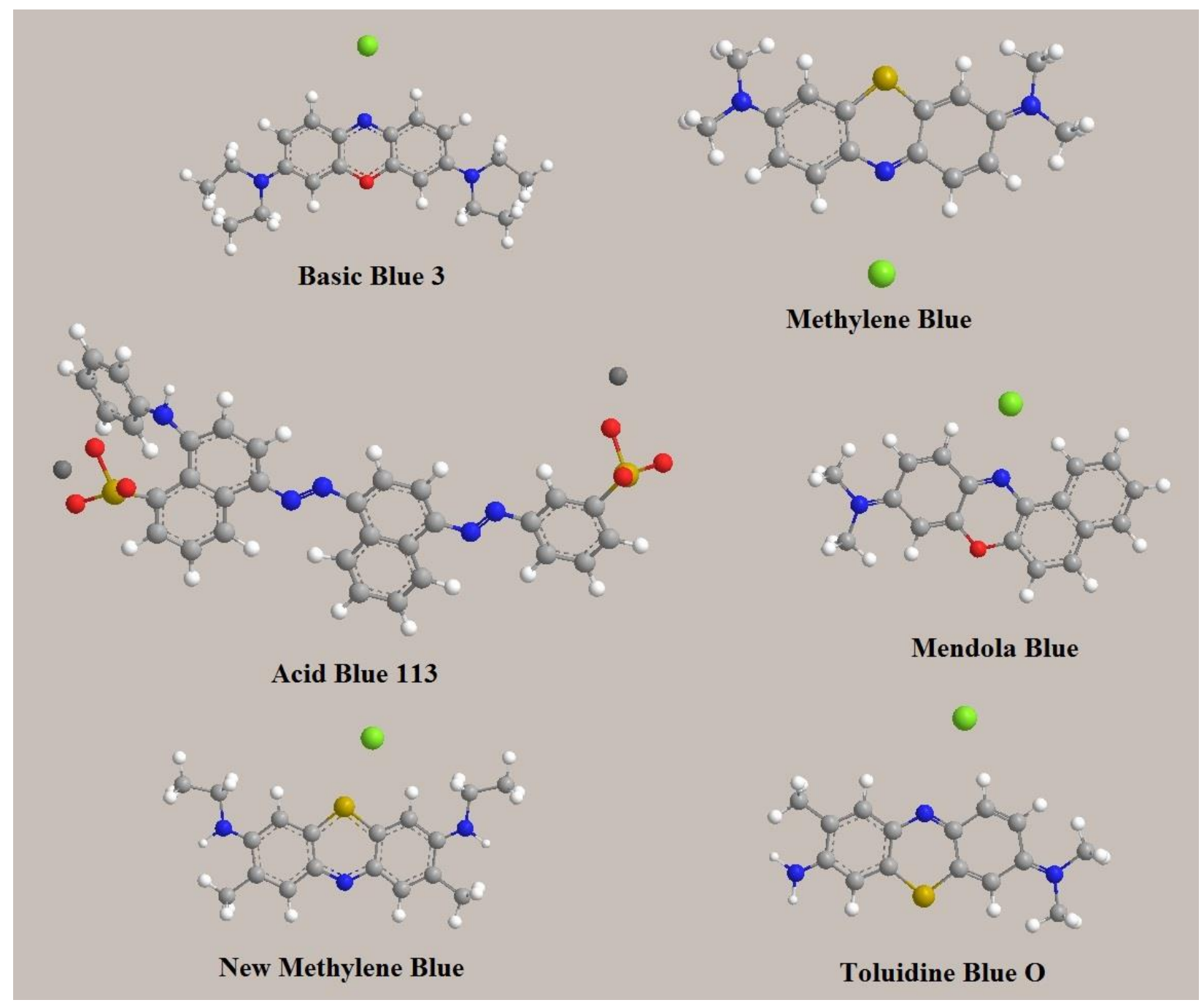

Figure 2. Examples of common blue dyes found in wastewater: Basic Blue 3, Methylene Blue, Acid Blue 113, Meldola Blue, New Methylene Blue, and Toluidine Blue O. (Atom colours: grey $-\mathrm{C}$, white $-\mathrm{H}$, red $-\mathrm{O}$, blue $-\mathrm{N}$, gold $-\mathrm{S}$, green $-\mathrm{Cl}^{-}, \mathrm{dark}$ grey $-\mathrm{Na}^{+}$) 
Dyes tend to fall into one of several varieties categorized by usage and structure, including basic (cationic), acidic (anionic), reactive, direct, disperse, azo, and metal-complex. Dyes also express high chemical diversity, so it is hardly surprising that no single adsorbent exists that is effective for all dyes. Examples of common dyes may be found in Figures 2-4. Even though activated carbon is usually considered to be the most efficient tool for the removal of dyes, its high cost and need for regeneration render it a less than ideal adsorbent. Accordingly, many lower cost-intensive alternatives have been investigated. The selection of one adsorbent material over another is usually based on the performance parameter, adsorption capacity. However, from a practical perspective, a number of additional factors such as market price, apparent density, and regeneration capacity also have to be considered. Table 1 lists a variety of adsorbents that have been employed for the removal of dyes from water, together with their adsorption capacity performance metric.

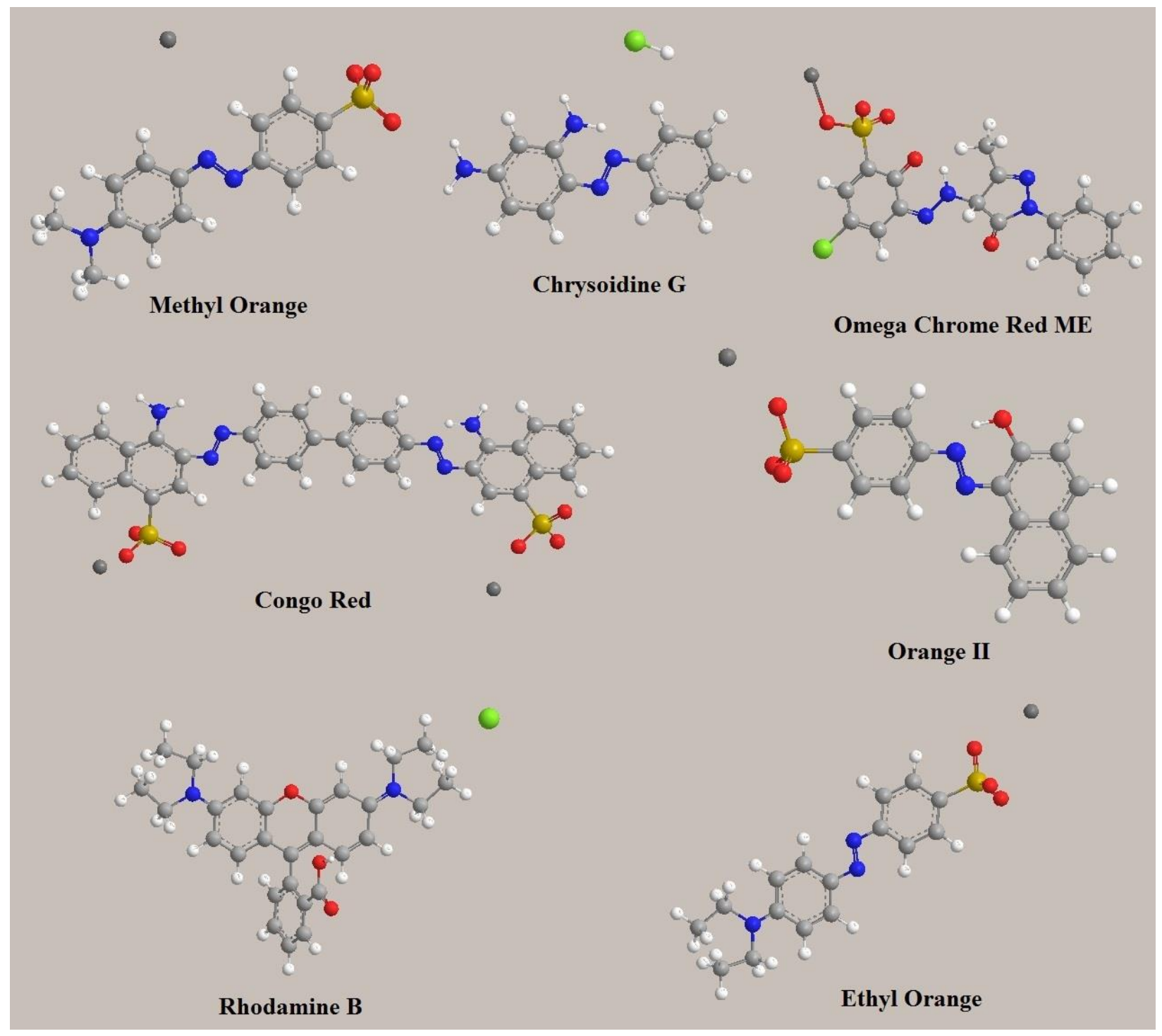

Figure 3. Examples of common orange and red dyes found in wastewater: Methyl Orange, Chrysoidine G, Omega Chrome Red $\mathrm{ME}$, Congo Red, Orange II, Rhodamine B, and Ethyl Orange. (Atom colours: grey $-\mathrm{C}$, white $-\mathrm{H}$, red $-\mathrm{O}$, blue $-\mathrm{N}$, gold $-\mathrm{S}$, green $-\mathrm{Cl}^{-}$, dark grey $-\mathrm{Na}^{+}$) 
Table 1. Reported adsorption capacities for various dyes encapsulated within in organic adsorbents. * marks entries where the chemical formula for this dye either does not appear to have been reported in the open literature, or only a generic formula is available.

\begin{tabular}{|c|c|c|c|c|}
\hline Adsorbent & Adsorbate & Adsorbate Formula & Maximum Capacity & Ref. \\
\hline Blast furnace sludge & Acid Blue 113 & $\mathrm{C}_{32} \mathrm{H}_{21} \mathrm{~N}_{5} \mathrm{Na}_{2} \mathrm{O}_{6} \mathrm{~S}_{2}$ & $2.1 \mathrm{mg} \mathrm{g}^{-1}$ & 60 \\
\hline Blast furnace dust & Acid Blue 113 & $\mathrm{C}_{32} \mathrm{H}_{21} \mathrm{~N}_{5} \mathrm{Na}_{2} \mathrm{O}_{6} \mathrm{~S}_{2}$ & negligible & 60 \\
\hline Foamed slag & Acid Blue 113 & $\mathrm{C}_{32} \mathrm{H}_{21} \mathrm{~N}_{5} \mathrm{Na}_{2} \mathrm{O}_{6} \mathrm{~S}_{2}$ & negligible & 60 \\
\hline Acid-activated bentonite & Acid Blue 294 & $*$ & $119.1 \mathrm{mg} \mathrm{g}^{-1}$ & 55 \\
\hline Acid-activated bentonite & Acid Red 57 & $\mathrm{C}_{24} \mathrm{H}_{22} \mathrm{~N}_{4} \mathrm{O}_{6} \mathrm{~S}_{2}$ & $416.3 \mathrm{mg} \mathrm{g}^{-1}$ & 55 \\
\hline Silica & Basic Blue 3 & $\mathrm{C}_{20} \mathrm{H}_{26} \mathrm{ClN}{ }_{3} \mathrm{O}$ & $6.27 \times 10^{6} \mathrm{mg} \mathrm{g}^{-1}$ & 61 \\
\hline Boron nitride hollow spheres & Basic Yellow 1 & $\mathrm{C}_{17} \mathrm{H}_{19} \mathrm{ClN}_{2} \mathrm{~S}$ & $191.7 \mathrm{mg} \mathrm{g}^{-1}$ & 62 \\
\hline Natural bentonite & Bezanyl Red & $*$ & $22.06 \mathrm{mg} \mathrm{g}^{-1}$ & 45 \\
\hline Acid-activated bentonite & Bezanyl Red & $*$ & $26.41 \mathrm{mg} \mathrm{g}^{-1}$ & 45 \\
\hline Blast furnace sludge & Chrysoidine G & $\mathrm{C}_{12} \mathrm{H}_{13} \mathrm{ClN}_{4}$ & $\sim 10 \mathrm{mg} \mathrm{g}^{-1}$ & 50 \\
\hline Blast furnace dust & Chrysoidine G & $\mathrm{C}_{12} \mathrm{H}_{13} \mathrm{ClN}_{4}$ & $\sim 6 \mathrm{mg} \mathrm{g}^{-1}$ & 50 \\
\hline Blast furnace slag & Chrysoidine G & $\mathrm{C}_{12} \mathrm{H}_{13} \mathrm{ClN}_{4}$ & $\sim 2 \mathrm{mg} \mathrm{g}^{-1}$ & 50 \\
\hline Waste red mud & Congo Red & $\mathrm{C}_{32} \mathrm{H}_{22} \mathrm{~N}_{6} \mathrm{Na}_{2} \mathrm{O}_{6} \mathrm{~S}_{2}$ & $4.05 \mathrm{mg} \mathrm{g}^{-1}$ & 53 \\
\hline Waste $\mathrm{Fe}(\mathrm{III}) / \mathrm{Cr}(\mathrm{III})$ hydroxide & Congo Red & $\mathrm{C}_{32} \mathrm{H}_{22} \mathrm{~N}_{6} \mathrm{Na}_{2} \mathrm{O}_{6} \mathrm{~S}_{2}$ & $17.9 \mathrm{mg} \mathrm{g}^{-1}$ & 54 \\
\hline $\begin{array}{l}\text { Sodium-dodecyl-sulfate- } \\
\text { modified alumina }\end{array}$ & Crystal Violet & $\mathrm{C}_{25} \mathrm{H}_{30} \mathrm{ClN} 3$ & $111.6 \mathrm{mg} \mathrm{g}^{-1}$ & 2 \\
\hline Blast furnace sludge & Crystal Violet & $\mathrm{C}_{25} \mathrm{H}_{30} \mathrm{ClN}_{3}$ & $\sim 25 \mathrm{mg} \mathrm{g}^{-1}$ & 50 \\
\hline Blast furnace dust & Crystal Violet & $\mathrm{C}_{25} \mathrm{H}_{30} \mathrm{ClN}_{3}$ & $\sim 10 \mathrm{mg} \mathrm{g}^{-1}$ & 50 \\
\hline Blast furnace slag & Crystal Violet & $\mathrm{C}_{25} \mathrm{H}_{30} \mathrm{ClN}_{3}$ & $\sim 4 \mathrm{mg} \mathrm{g}^{-1}$ & 50 \\
\hline MCM-22 & Crystal Violet & $\mathrm{C}_{25} \mathrm{H}_{30} \mathrm{ClN}_{3}$ & $0.12 \mathrm{mmol} \mathrm{g}^{-1}$ & 63 \\
\hline Blast furnace sludge & Ethyl Orange & $\mathrm{C}_{16} \mathrm{H}_{18} \mathrm{~N}_{3} \mathrm{NaO}_{3} \mathrm{~S}$ & $1.3 \mathrm{mg} \mathrm{g}^{-1}$ & 60 \\
\hline Blast furnace dust & Ethyl Orange & $\mathrm{C}_{16} \mathrm{H}_{18} \mathrm{~N}_{3} \mathrm{NaO}_{3} \mathrm{~S}$ & negligible & 60 \\
\hline Foamed slag & Ethyl Orange & $\mathrm{C}_{16} \mathrm{H}_{18} \mathrm{~N}_{3} \mathrm{NaO}_{3} \mathrm{~S}$ & negligible & 60 \\
\hline $\begin{array}{l}\text { HTAB-modified Turkish } \\
\text { clinoptilolite }\end{array}$ & Reactive Black 5 & $\mathrm{C}_{26} \mathrm{H}_{21} \mathrm{~N}_{5} \mathrm{Na}_{4} \mathrm{O}_{19} \mathrm{~S}_{6}$ & $2.9 \mathrm{mg} \mathrm{g}^{-1}$ & 48 \\
\hline HTAB-modified Clinoptilolite & Reactive Black 5 & $\mathrm{C}_{26} \mathrm{H}_{21} \mathrm{~N}_{5} \mathrm{Na}_{4} \mathrm{O}_{19} \mathrm{~S}_{6}$ & $60.6 \mathrm{mg} \mathrm{g}^{-1}$ & 64 \\
\hline HTAB-modified Sepiolite & Reactive Black 5 & $\mathrm{C}_{26} \mathrm{H}_{21} \mathrm{~N}_{5} \mathrm{Na}_{4} \mathrm{O}_{19} \mathrm{~S}_{6}$ & $120.5 \mathrm{mg} \mathrm{g}^{-1}$ & 64 \\
\hline $\begin{array}{l}\text { HTAB-modified Turkish } \\
\text { clinoptilolite }\end{array}$ & Reactive Red 239 & $\mathrm{C}_{31} \mathrm{H}_{19} \mathrm{ClN}_{7} \mathrm{Na}_{5} \mathrm{O}_{19} \mathrm{~S}_{6}$ & $3.7 \mathrm{mg} \mathrm{g}^{-1}$ & 48 \\
\hline HTAB-modified Clinoptilolite & Reactive Red 239 & $\mathrm{C}_{31} \mathrm{H}_{19} \mathrm{ClN}_{7} \mathrm{Na}_{5} \mathrm{O}_{19} \mathrm{~S}_{6}$ & $111.1 \mathrm{mg} \mathrm{g}^{-1}$ & 64 \\
\hline HTAB-modified Sepiolite & Reactive Red 239 & $\mathrm{C}_{31} \mathrm{H}_{19} \mathrm{ClN}_{7} \mathrm{Na}_{5} \mathrm{O}_{19} \mathrm{~S}_{6}$ & $108.8 \mathrm{mg} \mathrm{g}^{-1}$ & 64 \\
\hline $\begin{array}{l}\text { HTAB-modified Turkish } \\
\text { clinoptilolite }\end{array}$ & Reactive Yellow 176 & $\mathrm{C}_{28} \mathrm{H}_{23} \mathrm{ClN} 9 \mathrm{NaO}_{16} \mathrm{~S}_{5}$ & $7.6 \mathrm{mg} \mathrm{g}^{-1}$ & 48 \\
\hline HTAB-modified Clinoptilolite & Reactive Yellow 176 & $\mathrm{C}_{28} \mathrm{H}_{23} \mathrm{ClN}_{9} \mathrm{NaO}_{16} \mathrm{~S}_{5}$ & $88.5 \mathrm{mg} \mathrm{g}^{-1}$ & 64 \\
\hline HTAB-modified Sepiolite & Reactive Yellow 176 & $\mathrm{C}_{28} \mathrm{H}_{23} \mathrm{ClN} \mathrm{N}_{9} \mathrm{NaO}_{16} \mathrm{~S}_{5}$ & $169.1 \mathrm{mg} \mathrm{g}^{-1}$ & 64 \\
\hline Red mud & Fast Green & * & $9.35 \times 10^{-3} \mathrm{mmol} \mathrm{g}^{-1}$ & 49 \\
\hline Bentonite & Malachite green & $\mathrm{C}_{23} \mathrm{H}_{25} \mathrm{ClN}_{2}$ & $7.716 \mathrm{mg} \mathrm{g}^{-1}$ & 57 \\
\hline Blast furnace sludge & Meldola Blue & $\mathrm{C}_{18} \mathrm{H}_{15} \mathrm{ClN}_{2} \mathrm{O}$ & $\sim 70 \mathrm{mg} \mathrm{g}^{-1}$ & 50 \\
\hline Blast furnace dust & Meldola Blue & $\mathrm{C}_{18} \mathrm{H}_{15} \mathrm{ClN}_{2} \mathrm{O}$ & $\sim 35 \mathrm{mg} \mathrm{g}^{-1}$ & 50 \\
\hline Blast furnace slag & Meldola Blue & $\mathrm{C}_{18} \mathrm{H}_{15} \mathrm{ClN}_{2} \mathrm{O}$ & $\sim 4 \mathrm{mg} \mathrm{g}^{-1}$ & 50 \\
\hline Blast furnace sludge & Metanil Yellow & $\mathrm{C}_{18} \mathrm{H}_{14} \mathrm{~N}_{3} \mathrm{NaO}_{3} \mathrm{~S}$ & $1.4 \mathrm{mg} \mathrm{g}^{-1}$ & 60 \\
\hline
\end{tabular}




\begin{tabular}{|c|c|c|c|c|}
\hline Blast furnace dust & Metanil Yellow & $\mathrm{C}_{18} \mathrm{H}_{14} \mathrm{~N}_{3} \mathrm{NaO}_{3} \mathrm{~S}$ & negligible & 60 \\
\hline Foamed slag & Metanil Yellow & $\mathrm{C}_{18} \mathrm{H}_{14} \mathrm{~N}_{3} \mathrm{NaO}_{3} \mathrm{~S}$ & negligible & 60 \\
\hline $\begin{array}{l}\text { HBBN-1 (micro/mesoporous } \\
\text { boron nitride material) }\end{array}$ & Methyl Orange & $\mathrm{C}_{14} \mathrm{H}_{14} \mathrm{~N}_{3} \mathrm{NaO}_{3} \mathrm{~S}$ & $298.3 \mathrm{mg} \mathrm{g}^{-1}$ & 65 \\
\hline Red mud & Methylene Blue & $\mathrm{C}_{16} \mathrm{H}_{18} \mathrm{ClN}_{3} \mathrm{~S}$ & $0.523 \mathrm{mmol} \mathrm{g}^{-1}$ & 49 \\
\hline Unmodified zeolite & Methylene Blue & $\mathrm{C}_{16} \mathrm{H}_{18} \mathrm{ClN}_{3} \mathrm{~S}$ & $8.67 \mathrm{mg} \mathrm{g}^{-1}$ & 51 \\
\hline $\begin{array}{l}\text { Sodium-dodecyl- } \\
\text { benzenesulfonate-modified } \\
\text { zeolite }\end{array}$ & Methylene Blue & $\mathrm{C}_{16} \mathrm{H}_{18} \mathrm{ClN}_{3} \mathrm{~S}$ & $15.68 \mathrm{mg} \mathrm{g}^{-1}$ & 51 \\
\hline $\begin{array}{l}\text { Sodium-dodecyl-sulfate- } \\
\text { modified zeolite }\end{array}$ & Methylene Blue & $\mathrm{C}_{16} \mathrm{H}_{18} \mathrm{ClN}_{3} \mathrm{~S}$ & $14.87 \mathrm{mg} \mathrm{g}^{-1}$ & 51 \\
\hline $\begin{array}{l}\text { Hexadecylammonium-bromide- } \\
\text { templated } \mathrm{TiO}_{2}\left(\mathrm{HTAB}+\mathrm{TiO}_{2}\right)\end{array}$ & Methylene Blue & $\mathrm{C}_{16} \mathrm{H}_{18} \mathrm{ClN}_{3} \mathrm{~S}$ & $\sim 0.20 \mathrm{mmol} \mathrm{g}^{-1}$ & 47 \\
\hline $\begin{array}{l}\text { Dodecyltrimethylammonium- } \\
\text { bromide-templated } \mathrm{TiO}_{2} \\
\left(\mathrm{DTAB}+\mathrm{TiO}_{2}\right)\end{array}$ & Methylene Blue & $\mathrm{C}_{16} \mathrm{H}_{18} \mathrm{ClN}_{3} \mathrm{~S}$ & $\sim 0.33 \mathrm{mmol} \mathrm{g}^{-1}$ & 47 \\
\hline $\begin{array}{l}\text { Dodecyltrimethylammonium- } \\
\text { templated } \mathrm{TiO}_{2}\left(\mathrm{DDAB}+\mathrm{TiO}_{2}\right)\end{array}$ & Methylene Blue & $\mathrm{C}_{16} \mathrm{H}_{18} \mathrm{ClN}_{3} \mathrm{~S}$ & $\sim 0.05 \mathrm{mmol} \mathrm{g}^{-1}$ & 47 \\
\hline HTAB & Methylene Blue & $\mathrm{C}_{16} \mathrm{H}_{18} \mathrm{ClN}_{3} \mathrm{~S}$ & $\sim 0.13 \mathrm{mmol} \mathrm{g}^{-1}$ & 47 \\
\hline DDAB & Methylene Blue & $\mathrm{C}_{16} \mathrm{H}_{18} \mathrm{ClN}_{3} \mathrm{~S}$ & $\sim 0.05 \mathrm{mmol} \mathrm{g}^{-1}$ & 47 \\
\hline Fly ash & Methylene Blue & $\mathrm{C}_{16} \mathrm{H}_{18} \mathrm{ClN}_{3} \mathrm{~S}$ & $0.014 \mathrm{mmol} \mathrm{g}^{-1}$ & 66 \\
\hline Fly ash treated with $\mathrm{HNO}_{3}$ & Methylene Blue & $\mathrm{C}_{16} \mathrm{H}_{18} \mathrm{ClN}_{3} \mathrm{~S}$ & $0.025 \mathrm{mmol} \mathrm{g}^{-1}$ & 66 \\
\hline Red mud & Methylene Blue & $\mathrm{C}_{16} \mathrm{H}_{18} \mathrm{ClN}_{3} \mathrm{~S}$ & $0.0078 \mathrm{mmol} \mathrm{g}^{-1}$ & 66 \\
\hline MCM-41 & Methylene Blue & $\mathrm{C}_{16} \mathrm{H}_{18} \mathrm{ClN}_{3} \mathrm{~S}$ & $0.0401 \mathrm{mmol} \mathrm{g}^{-1}$ & 67 \\
\hline MCM-48 & Methylene Blue & $\mathrm{C}_{16} \mathrm{H}_{18} \mathrm{ClN}_{3} \mathrm{~S}$ & $0.0361 \mathrm{mmol} \mathrm{g}^{-1}$ & 67 \\
\hline MCM-50 & Methylene Blue & $\mathrm{C}_{16} \mathrm{H}_{18} \mathrm{ClN}_{3} \mathrm{~S}$ & $0.0725 \mathrm{mmol} \mathrm{g}^{-1}$ & 67 \\
\hline Zeolite (mainly clinoptilolite) & Methylene Blue & $\mathrm{C}_{16} \mathrm{H}_{18} \mathrm{ClN}_{3} \mathrm{~S}$ & $0.037 \mathrm{mmol} \mathrm{g}^{-1}$ & 68 \\
\hline $\begin{array}{l}\text { Zeolite regenerated by high } \\
\text { temperature calcination }\end{array}$ & Methylene Blue & $\mathrm{C}_{16} \mathrm{H}_{18} \mathrm{ClN}_{3} \mathrm{~S}$ & $0.022 \mathrm{mmol} \mathrm{g}^{-1}$ & 68 \\
\hline $\begin{array}{l}\text { Zeolite regenerated by Fenton } \\
\text { oxidation }\end{array}$ & Methylene Blue & $\mathrm{C}_{16} \mathrm{H}_{18} \mathrm{ClN}_{3} \mathrm{~S}$ & $0.02 \mathrm{mmol} \mathrm{g}^{-1}$ & 68 \\
\hline MCM-22 & Methylene Blue & $\mathrm{C}_{16} \mathrm{H}_{18} \mathrm{ClN}_{3} \mathrm{~S}$ & $0.168 \mathrm{mmol} \mathrm{g}^{-1}$ & 68 \\
\hline $\begin{array}{l}\text { MCM- } 22 \text { regenerated by high } \\
\text { temperature calcination }\end{array}$ & Methylene Blue & $\mathrm{C}_{16} \mathrm{H}_{18} \mathrm{ClN}_{3} \mathrm{~S}$ & $0.182 \mathrm{mmol} \mathrm{g}^{-1}$ & 68 \\
\hline $\begin{array}{l}\text { MCM- } 22 \text { regenerated by } \\
\text { Fenton oxidation }\end{array}$ & Methylene Blue & $\mathrm{C}_{16} \mathrm{H}_{18} \mathrm{ClN}_{3} \mathrm{~S}$ & $0.10 \mathrm{mmol} \mathrm{g}^{-1}$ & 68 \\
\hline MCM-22 & Methylene Blue & $\mathrm{C}_{16} \mathrm{H}_{18} \mathrm{ClN}_{3} \mathrm{~S}$ & $0.18 \mathrm{mmol} \mathrm{g}^{-1}$ & 63 \\
\hline Natural zeolite & Methylene Blue & $\mathrm{C}_{16} \mathrm{H}_{18} \mathrm{ClN}_{3} \mathrm{~S}$ & $0.063 \mathrm{mmol} \mathrm{g}^{-1}$ & 69 \\
\hline Boron nitride hollow spheres & Methylene Blue & $\mathrm{C}_{16} \mathrm{H}_{18} \mathrm{ClN}_{3} \mathrm{~S}$ & $116.5 \mathrm{mg} \mathrm{g}^{-1}$ & 62 \\
\hline $\begin{array}{l}\text { Natural zeolite ( } 90 \% \\
\text { clinoptilolite) }\end{array}$ & $\begin{array}{l}\text { Maxilon Schwarz } \\
\text { FBL-01 300\% (MS- } \\
300)\end{array}$ & $*$ & $\sim 5 \mathrm{mg} \mathrm{g}^{-1}$ & 70 \\
\hline $\begin{array}{l}\text { Natural zeolite }(90 \% \\
\text { clinoptilolite) }\end{array}$ & $\begin{array}{l}\text { Maxilon Goldgelb GL } \\
\text { EC 400\% (MG-400) }\end{array}$ & $*$ & $\sim 8 \mathrm{mg} \mathrm{g}^{-1}$ & 70 \\
\hline Mordenite zeolite & New methylene blue & $\mathrm{C}_{18} \mathrm{H}_{22} \mathrm{ClN}_{3} \mathrm{~S}$ & $0.08 \mathrm{mmol} \mathrm{g}^{-1}$ & 71 \\
\hline Mordenite nanocrystals & New methylene blue & $\mathrm{C}_{18} \mathrm{H}_{22} \mathrm{ClN}_{3} \mathrm{~S}$ & $0.12 \mathrm{mmol} \mathrm{g}^{-1}$ & 71 \\
\hline Natural bentonite & Nylomine Green & $\mathrm{C}_{28} \mathrm{H}_{20} \mathrm{~N}_{2} \mathrm{Na}_{2} \mathrm{O}_{8} \mathrm{~S}_{2}$ & $10.64 \mathrm{mg} \mathrm{g}^{-1}$ & 45 \\
\hline Acid-activated bentonite & Nylomine Green & $\mathrm{C}_{28} \mathrm{H}_{20} \mathrm{~N}_{2} \mathrm{Na}_{2} \mathrm{O}_{8} \mathrm{~S}_{2}$ & $14.78 \mathrm{mg} \mathrm{g}^{-1}$ & 45 \\
\hline China clay & $\begin{array}{l}\text { Omega Chrome Red } \\
\mathrm{ME}\end{array}$ & $\mathrm{C}_{16} \mathrm{H}_{12} \mathrm{ClN}_{4} \mathrm{NaO}_{5} \mathrm{~S}$ & $0.49 \mathrm{mg} \mathrm{g}^{-1}$ & 72 \\
\hline
\end{tabular}




\begin{tabular}{|c|c|c|c|c|}
\hline Unmodified zeolite & Orange II & $\mathrm{C}_{16} \mathrm{H}_{11} \mathrm{~N}_{2} \mathrm{NaO}_{4} \mathrm{~S}$ & $0.63 \mathrm{mg} \mathrm{g}^{-1}$ & 51 \\
\hline $\begin{array}{l}\text { Cetylpyridinium-bromide- } \\
\text { hexadecyl-modified zeolite }\end{array}$ & Orange II & $\mathrm{C}_{16} \mathrm{H}_{11} \mathrm{~N}_{2} \mathrm{NaO}_{4} \mathrm{~S}$ & $3.01 \mathrm{mg} \mathrm{g}^{-1}$ & 51 \\
\hline $\begin{array}{l}\text { Hexadecylammonium-bromide- } \\
\text { modified zeolite }\end{array}$ & Orange II & $\mathrm{C}_{16} \mathrm{H}_{11} \mathrm{~N}_{2} \mathrm{NaO}_{4} \mathrm{~S}$ & $3.38 \mathrm{mg} \mathrm{g}^{-1}$ & 51 \\
\hline Vermiculite & Cationic Blue & $*$ & $107 \mathrm{mg} \mathrm{g}^{-1}$ & 58 \\
\hline $\begin{array}{l}\text { Sonication-surfactant-modified } \\
\text { attapulgite clay }\end{array}$ & Reactive Red MF-3B & $*$ & $85.47 \mathrm{mg} \mathrm{g}^{-1}$ & 73 \\
\hline Vermiculite & $\begin{array}{l}\text { Real Textile } \\
\text { wastewater }\end{array}$ & $*$ & $85 \%$ & 58 \\
\hline Red mud & Rhodamine B & $\mathrm{C}_{28} \mathrm{H}_{31} \mathrm{ClN}_{2} \mathrm{O}_{3}$ & $0.0116 \mathrm{mmol} \mathrm{g}^{-1}$ & 49 \\
\hline $\begin{array}{l}\text { Hexadecylammonium-bromide- } \\
\text { templated } \mathrm{TiO}_{2}\left(\mathrm{HTAB}+\mathrm{TiO}_{2}\right)\end{array}$ & Rhodamine B & $\mathrm{C}_{28} \mathrm{H}_{31} \mathrm{ClN}_{2} \mathrm{O}_{3}$ & $\sim 0.09 \mathrm{mmol} \mathrm{g}^{-1}$ & 47 \\
\hline $\begin{array}{l}\text { Dodecyltrimethylammonium- } \\
\text { bromide-templated } \mathrm{TiO}_{2} \\
\left(\mathrm{DTAB}+\mathrm{TiO}_{2}\right)\end{array}$ & Rhodamine B & $\mathrm{C}_{28} \mathrm{H}_{31} \mathrm{ClN}_{2} \mathrm{O}_{3}$ & $\sim 0.04 \mathrm{mmol} \mathrm{g}^{-1}$ & 47 \\
\hline $\begin{array}{l}\text { Dodecyltrimethylammonium- } \\
\text { templated } \mathrm{TiO}_{2}\left(\mathrm{DDAB}+\mathrm{TiO}_{2}\right)\end{array}$ & Rhodamine B & $\mathrm{C}_{28} \mathrm{H}_{31} \mathrm{ClN}_{2} \mathrm{O}_{3}$ & $\sim 0.02 \mathrm{mmol} \mathrm{g}^{-1}$ & 47 \\
\hline $\begin{array}{l}\text { Hexadecyltrimethylammonium } \\
\text { bromide (HTAB) }\end{array}$ & Rhodamine B & $\mathrm{C}_{28} \mathrm{H}_{31} \mathrm{ClN}_{2} \mathrm{O}_{3}$ & $\sim 0.05 \mathrm{mmol} \mathrm{g}^{-1}$ & 47 \\
\hline $\begin{array}{l}\text { Didodecyldimethylammonium } \\
\text { (DDAB) }\end{array}$ & Rhodamine B & $\mathrm{C}_{28} \mathrm{H}_{31} \mathrm{ClN}_{2} \mathrm{O}_{3}$ & $\sim 0.03 \mathrm{mmol} \mathrm{g}^{-1}$ & 47 \\
\hline MCM-22 & Rhodamine B & $\mathrm{C}_{28} \mathrm{H}_{31} \mathrm{ClN}_{2} \mathrm{O}_{3}$ & $0.110 \mathrm{mmol} \mathrm{g}^{-1}$ & 63 \\
\hline Natural zeolite & Rhodamine B & $\mathrm{C}_{28} \mathrm{H}_{31} \mathrm{ClN}_{2} \mathrm{O}_{3}$ & $0.0258 \mathrm{mmol} \mathrm{g}^{-1}$ & 69 \\
\hline Turkish clinoptilolite & Toluidine Blue $O$ & $\mathrm{C}_{15} \mathrm{H}_{16} \mathrm{ClN}_{3} \mathrm{~S}$ & $0.21 \mathrm{mmol} \mathrm{g}^{-1}$ & 74 \\
\hline Gypsum & Toluidine Blue $\mathrm{O}$ & $\mathrm{C}_{15} \mathrm{H}_{16} \mathrm{ClN}_{3} \mathrm{~S}$ & $28 \mathrm{mg} \mathrm{g}^{-1}$ & 56 \\
\hline
\end{tabular}

The use of industrial waste products such as blast furnace waste from steel plants, ${ }^{50,60}$ red mud from the alumina industry, ${ }^{49,53,66}$ fly ash from coal plants, 66 and 'waste' $\mathrm{Fe}^{3+} / \mathrm{Cr}^{3+}$ hydroxide from the treatment of $\mathrm{Cr}^{+6} 54$ represents one of the least expensive strategies to remove dyes from water. While blast furnace waste such as slag, sludge, and dust does not adsorb acid or basic dyes effectively, red mud, fly ash, and $\mathrm{Fe}^{3+} / \mathrm{Cr}^{3+}$ hydroxide proves to be more promising.

When considering the removal of dyes from wastewater using red mud, Namasivayam and Arasi (1997) ${ }^{53}$ reported dyeconcentration-dependent efficiencies of $\sim 25-36 \%$ for Congo Red, while Gupta et al. (2004) ${ }^{49}$ reported efficiencies of $\sim 71-97 \%$ (depending on the removal method) for Rhodamine B, Fast Green, and Methylene Blue. Wang et al. (2005)66 reported that the basic dye, Methylene Blue, adsorbed better on fly ash than on red mud, while Namasivayan et al. (1994) ${ }^{54}$ reported a $91 \%$ removal efficiency for Congo Red at $\mathrm{pH} 3$ using $\mathrm{Fe}^{3+} / \mathrm{Cr}^{3+}$ hydroxide .

Clays and minerals represent another promising type of dye adsorbents, among which the acid-activated aluminasilicate clay bentonite carries a particularly interesting prospective. Özcan and Özcan (2004) $)^{55}$ reported very high adsorption capacities for acid dyes, such as Acid Red 57 (416.3 $\mathrm{mg} \mathrm{g}^{-1}$ at $20^{\circ} \mathrm{C}$ ) and Acid Blue 294 (119.1 $\mathrm{mg} \mathrm{g}^{-1}$ at $20^{\circ} \mathrm{C}$ ), which are commonly used in the textile industry. Tahir and Rauf (2006) $)^{57}$ found that the adsorption capacity for the cationic dye, Malachite Green, in bentonite is heavily influenced by the $\mathrm{pH}$ value of the dye solution, and that adsorption efficiencies increased (29\%-91\%) with increasing $\mathrm{pH}$, considered in the region $\mathrm{pH}=2$.0-9.0. Other clays, such as attapulgite, were also investigated and adsorbed Reactive Red MF-3B, albeit efficiency was low, even after activation with acid. ${ }^{73}$ However, a modification of the attapulgite clay with organic surfactants increased the uptake percentage of Reactive Red MF-3B by a factor of 7-8. Lambert et al. (1997) ${ }^{75}$ investigated activated bauxite, fullers earth, and a synthetic hydrotalcite clay for the removal of the reactive dyes Procion Turquoise H-A (Colour Index Reactive Blue 71), Procion Red H-E3B (Colour Index Reactive Red 120), and Remazol Red RB (Colour Index Reactive Red 198) from textile industry effluents. The synthetic hydrotalcite clay was more effective than activated carbon, under moderate $\mathrm{pH}$ and temperature conditions $\left(\mathrm{pH}=5.5-8.5 ; \mathrm{T}=20-40{ }^{\circ} \mathrm{C}\right)$. In contrast, $\mathrm{CT} 100$ hydrotalcite clay only exhibited a limited capacity for the removal of dyes. ${ }^{46}$ Rauf et al. (2009) ${ }^{56}$ investigated the suitability of the sulfate mineral, gypsum, for the 
adsorption of Toluidine Blue from aqueous solution ( $28 \mathrm{mg} \mathrm{g}^{-1}$ at room temperature) but concluded, upon comparison with literature precedents, that its performance was inferior to that of Turkish clinoptilolite.

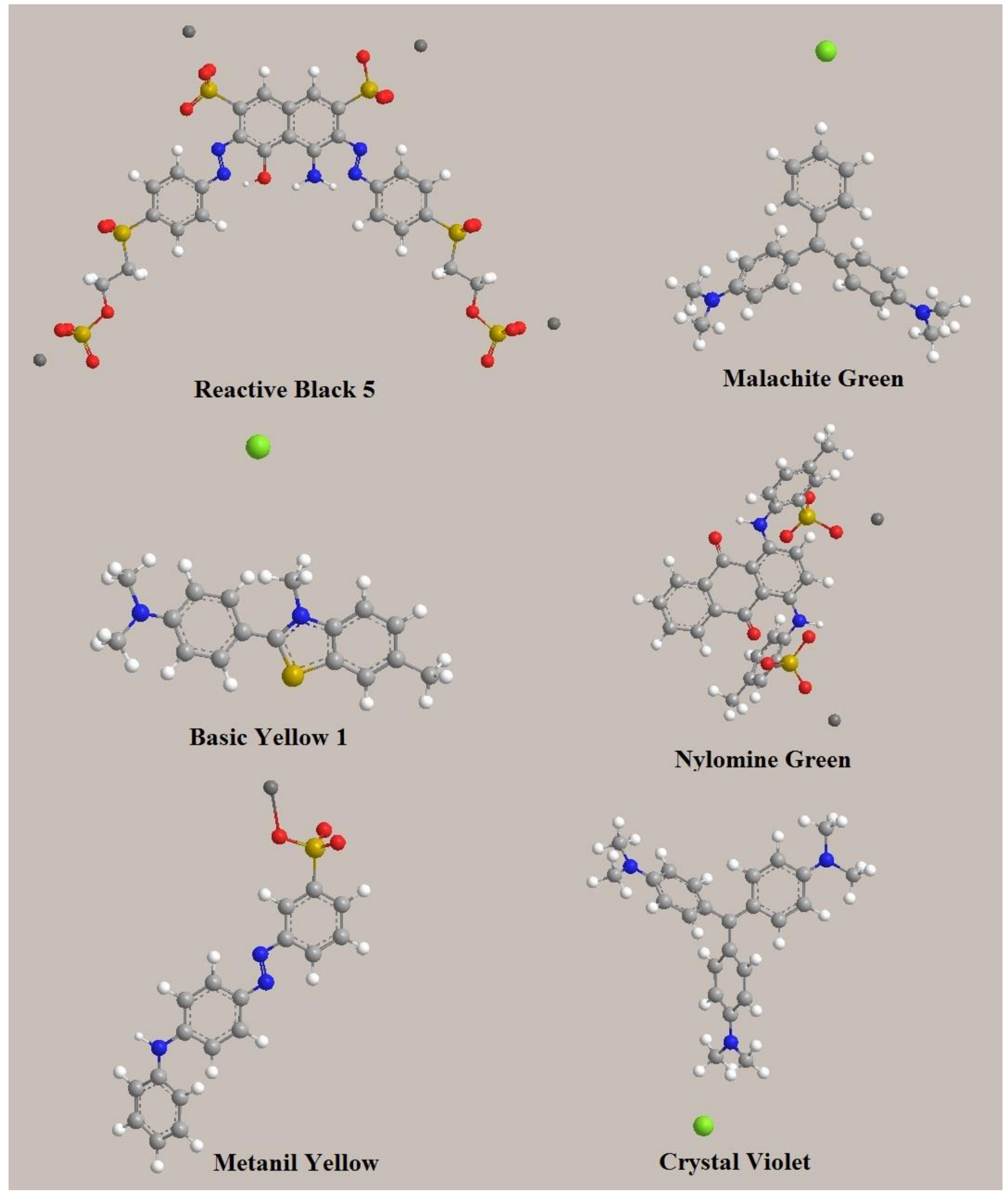

Figure 4. Examples of common green and yellow dyes found in wastewater, along with a black and a violet dye: Reactive Black 5, Malachite Green, Basic Yellow 1, Nylomine Green, Metanil Yellow, and Crystal Violet. (Atom colours: grey - C, white - H, red $-\mathrm{O}$, blue $-\mathrm{N}$, gold $-\mathrm{S}$, green $-\mathrm{Cl}^{-}$, dark grey $-\mathrm{Na}^{+}$) 
Alumina- and silica-based compounds have also been investigated in the context of dye adsorption. For example, silica was tested for its capability to adsorb of Basic Blue 3;61 the results of which revealed that the uptake depended on temperature, $\mathrm{pH}$, sorbent concentration, and dye concentration. Cognate comparisons with other adsorbents were not included. Wang and $\mathrm{Li}$ $(2006)^{67}$ investigated the adsorption properties of Methylene Blue on the synthetic mesoporous silicates, MCM-41, MCM-48, and MCM-50. They observed that MCM-41 and MCM-48 exhibited a comparable adsorption capacity $\left(4.01 \times 10^{-5} \mathrm{~mol} / \mathrm{g}\right.$ for MCM-41, $\left.3.61 \times 10^{-5} \mathrm{~mol} / \mathrm{g}\right)$, which was lower than that of MCM-50 $\left(7.25 \times 10^{-5} \mathrm{~mol} / \mathrm{g}\right)$. The authors also reported that such adsorption was reversible for MCM-41 and MCM-48, while it was irreversible for MCM-50. Adak et al. (2005) ${ }^{2}$ reported that within an aquatic environment, untreated alumina adsorbs the basic dye, Crystal Violet, with only $6 \%$ efficiency; yet it could be increased to $~ 99 \%$ efficiency upon modification with an organic surfactant. Their study found a slow improvement in Crystal Violet uptake with increasing surfactant coverage, ranging from $0 \mathrm{mg} / \mathrm{g}$ to ca. $110 \mathrm{mg} / \mathrm{g}$. Furthermore, uptake was highest at around $\mathrm{pH} 8$, and variations in temperature from $15-35^{\circ} \mathrm{C}$ had no effect on removal of the dye.

Zeolites represent another well-established class of porous materials, which have been investigated in the context of dye adsorption from wastewater. Unfortunately, numerous studies suggest that natural zeolites could be generally unsuitable, or have a limited capacity for the adsorption of dyes from aqueous solutions. ${ }^{46,48,51,64,70}$ For example, natural zeolites exhibit a very low level of adsorption of reactive azo dyes such as anionic Orange II $\left(0.05 \mathrm{mg} \mathrm{g}^{-1}\right),{ }^{51}$ while they adsorb basic dyes such as Methylene Blue, ${ }^{51,68,69,71}$ Rhodamine $B,{ }^{63,69}$ and phenothiazine Toluidine Blue $O$ with reasonable efficiency. ${ }^{74}$ However, several studies concluded that the modification of natural zeolites with organic surfactants can significantly improve their adsorption performance. $48,51,64$ Synthetic zeolites, particularly MCM-22, often substantially outperform their natural counterparts, and frequently exhibit an uptake that is comparable to activated carbon-based adsorbents.63,68 Sohrabnezhad and Pourahmad (2010) ${ }^{71}$ investigated the removal of New Methylene Blue from aqueous solution using the nanocrystalline zeolite, mordenite. They observed an adsorption uptake (adsorption capacity $0.12 \mathrm{mmol} / \mathrm{g}$ ) close to that of activated carbon (adsorption capacity $0.268-1.38 \mathrm{mmol} / \mathrm{g})$.

2.2 The removal of heavy metal ions from wastewater. Most heavy metal ions are toxic to biological systems and are usually not biodegradable, which may lead to the potentially dangerous accumulation of heavy metals higher up the food chain. This problem is especially acute when heavy metal ions enter the aquatic ecosystem, where they can cause a variety of health ${ }^{76}$ and environmental problems. ${ }^{77}$ Heavy metal ions may enter the aquatic ecosystem from a variety of sources, which include industrial waste, drainage water from motorways, and industrial mining. However, the removal of metal ions from aqueous sources can also be used for the recovery of precious resources, such as recovering and recycling $\mathrm{Li}^{+}$ions from seawater for use in batteries. ${ }^{78,79}$ It is therefore hardly surprising that various adsorbents have been explored extensively for their prospective removal of heavy metal ions from water. Indeed, several reviews focus, in particular, on cost-effective materials. 6,80,81 Table 2 catalogues the variety of adsorbents that have been investigated for the removal of heavy metal ions from aqueous sources, against which their adsorption capacities are recorded.

Table 2. Reported inorganic adsorbents used to encapsulate heavy metal ions together with their adsorption capacity performance metrics. 


\begin{tabular}{|c|c|c|c|}
\hline Adsorbent & Adsorbate & Maximum Reported Capacity & Ref. \\
\hline Fe-Mn hydrous oxide & $\mathrm{As}^{3+}$ & $47.6 \mathrm{mg} \mathrm{g}^{-1}$ & 82 \\
\hline $\mathrm{H}_{1.6} \mathrm{Mn}_{1.6} \mathrm{O}_{4}(\mathrm{HT})$ & $\mathrm{Ca}^{2+}$ & $3.8 \mathrm{mg} \mathrm{g}^{-1}$ & 78 \\
\hline $\mathrm{H}_{1.6} \mathrm{Mn}_{1.6} \mathrm{O}_{4}(\mathrm{RF})$ & $\mathrm{Ca}^{2+}$ & $2.4 \mathrm{mg} \mathrm{g}^{-1}$ & 78 \\
\hline $\mathrm{NaCl}$-treated zeolitictuff & $\mathrm{Cd}^{2+}$ & $17.63 \mathrm{mg} \mathrm{g}^{-1}$ & 83 \\
\hline ZeoAds - zeolite by-product mixed with Portland cement & $\mathrm{Cd}^{2+}$ & $10.87 \mathrm{mg} \mathrm{g}^{-1}$ & 84 \\
\hline Clinoptilolite & $\mathrm{Cd}^{2+}$ & $3.7 \mathrm{mg} \mathrm{g}^{-1}$ & 85 \\
\hline Chabazite & $\mathrm{Cd}^{2+}$ & $6.7 \mathrm{mg} \mathrm{g}^{-1}$ & 85 \\
\hline Clinoptilolite & Cobalt ions & $1.5 \mathrm{mg} \mathrm{g}^{-1}$ & 85 \\
\hline Chabazite & Cobalt ions & $5.8 \mathrm{mg} \mathrm{g}^{-1}$ & 85 \\
\hline Natural zeolite & $\mathrm{Co}^{2+}$ & $0.244 \mathrm{mmol} \mathrm{g}^{-1}$ & 86 \\
\hline Coal fly ash prepared zeolite $4 \mathrm{~A}$ treated with $\mathrm{NaCl}$ & $\mathrm{Co}^{2+}$ & $16.84 \mathrm{mg} \mathrm{g}^{-1}$ & 87 \\
\hline Clinoptilolite & Chromium ions & $2.4 \mathrm{mg} \mathrm{g}^{-1}$ & 85 \\
\hline Chabazite & Chromium ions & $3.6 \mathrm{mg} \mathrm{g}^{-1}$ & 85 \\
\hline Coal fly ash prepared zeolite $4 \mathrm{~A}$ treated with $\mathrm{NaCl}$ & $\mathrm{Cr}^{3+}$ & $56.41 \mathrm{mg} \mathrm{g}^{-1}$ & 87 \\
\hline ZeoAds - zeolite by-product mixed with Portland cement & Copperions & $23.25 \mathrm{mg} \mathrm{g}^{-1}$ & 84 \\
\hline Clinoptilolite & Copperions & $3.8 \mathrm{mg} \mathrm{g}^{-1}$ & 85 \\
\hline Chabazite & Copperions & $5.1 \mathrm{mg} \mathrm{g}^{-1}$ & 85 \\
\hline HBBN-1 (micro/mesoporous boron nitride material) & Copperions & $373 \mathrm{mg} \mathrm{g}^{-1}$ & 65 \\
\hline Natural zeolite & $\mathrm{Cu}^{2+}$ & $0.141 \mathrm{mmol} \mathrm{g}^{-1}$ & 86 \\
\hline Coal fly ash prepared zeolite $4 \mathrm{~A}$ treated with $\mathrm{NaCl}$ & $\mathrm{Cu}^{2+}$ & $72.04 \mathrm{mg} \mathrm{g}^{-1}$ & 87 \\
\hline Natural zeolite & $\mathrm{Cu}^{2+}$ & $0.54 \mathrm{mg} \mathrm{g}^{-1}$ & 88 \\
\hline Natural zeolite & $\mathrm{Fe}^{3+}$ & $6.41 \mathrm{mg} \mathrm{g}^{-1}$ & 88 \\
\hline Natural zeolite & Mercury ions & $9.2 \times 10^{-3} \mathrm{mg} \mathrm{g}^{-1}$ & 89 \\
\hline Natural bentonite & Mercury ions & $7.4 \times 10^{-3} \mathrm{mg} \mathrm{g}^{-1}$ & 89 \\
\hline $\mathrm{H}_{1.6} \mathrm{Mn}_{1.6} \mathrm{O}_{4}(\mathrm{HT})$ & $\mathrm{K}^{+}$ & $0.6 \mathrm{mg} \mathrm{g}^{-1}$ & 78 \\
\hline $\mathrm{H}_{1.6} \mathrm{Mn}_{1.6} \mathrm{O}_{4}(\mathrm{RF})$ & $\mathrm{K}^{+}$ & $0.3 \mathrm{mg} \mathrm{g}^{-1}$ & 78 \\
\hline $\mathrm{H}_{1.6} \mathrm{Mn}_{1.6} \mathrm{O}_{4}(\mathrm{HT})$ & $\mathrm{Li}^{+}$ & $40.9 \mathrm{mg} \mathrm{g}^{-1}$ & 78 \\
\hline $\mathrm{H}_{1.6} \mathrm{Mn}_{1.6} \mathrm{O}_{4}(\mathrm{RF})$ & $\mathrm{Li}^{+}$ & $34.1 \mathrm{mg} \mathrm{g}^{-1}$ & 78 \\
\hline $\mathrm{H}_{1.6} \mathrm{Mn}_{1.6} \mathrm{O}_{4}(\mathrm{HT})$ & $\mathrm{Mg}^{2+}$ & $1.5 \mathrm{mg} \mathrm{g}^{-1}$ & 78 \\
\hline $\mathrm{H}_{1.6} \mathrm{Mn}_{1.6} \mathrm{O}_{4}(\mathrm{RF})$ & $\mathrm{Mg}^{2+}$ & $2.2 \mathrm{mg} \mathrm{g}^{-1}$ & 78 \\
\hline Natural zeolite & $\mathrm{Mn}^{2+}$ & $0.077 \mathrm{mmol} \mathrm{g}^{-1}$ & 86 \\
\hline Natural zeolite & $\mathrm{Mn}^{2+}$ & $0.52 \mathrm{mg} \mathrm{g}^{-1}$ & 88 \\
\hline $\mathrm{H}_{1.6} \mathrm{Mn}_{1.6} \mathrm{O}_{4}(\mathrm{HT})$ & $\mathrm{Na}^{+}$ & $7.6 \mathrm{mg} \mathrm{g}^{-1}$ & 78 \\
\hline $\mathrm{H}_{1.6} \mathrm{Mn}_{1.6} \mathrm{O}_{4}(\mathrm{RF})$ & $\mathrm{Na}^{+}$ & $2.6 \mathrm{mg} \mathrm{g}^{-1}$ & 78 \\
\hline Clinoptilolite & Nickel ions & $0.9 \mathrm{mg} \mathrm{g}^{-1}$ & 85 \\
\hline Chabazite & Nickel ions & $4.5 \mathrm{mg} \mathrm{g}^{-1}$ & 85 \\
\hline Coal fly ash prepared zeolite $4 \mathrm{~A}$ treated with $\mathrm{NaCl}$ & $\mathrm{Ni}^{2+}$ & $11.51 \mathrm{mg} \mathrm{g}^{-1}$ & 87 \\
\hline
\end{tabular}




\begin{tabular}{|c|c|c|c|}
\hline ZeoAds - zeolite by-product mixed with Portland cement & Lead ions & $27.03 \mathrm{mg} \mathrm{g}^{-1}$ & 84 \\
\hline Clinoptilolite & Lead ions & $6.0 \mathrm{mg} \mathrm{g}^{-1}$ & 85 \\
\hline Chabazite & Lead ions & $6.0 \mathrm{mg} \mathrm{g}^{-1}$ & 85 \\
\hline $\mathrm{Fe}_{2} \mathrm{O}_{3} \cdot \mathrm{Al}_{2} \mathrm{O}_{3} \cdot \mathrm{xH}_{2} \mathrm{O}$ & Phosphate ions & $22.9 \mathrm{mg} \mathrm{g}^{-1}$ & 90 \\
\hline $\mathrm{Fe}_{2} \mathrm{O}_{3} \cdot 2 \mathrm{Al}_{2} \mathrm{O}_{3} \cdot x \mathrm{H}_{2} \mathrm{O}$ & Phosphate ions & $20.8 \mathrm{mg} \mathrm{g}^{-1}$ & 90 \\
\hline Red mud treated with $\mathrm{HCl}$ & Phosphate ions & $0.58 \mathrm{mg} \mathrm{g}^{-1}$ & 91 \\
\hline Raw red mud & Phosphate ions & $0.29 \mathrm{mg} \mathrm{g}^{-1}$ & 91 \\
\hline Fe-Mn hydrous oxide & $\mathrm{Se}^{4+}$ & $29.0 \mathrm{mg} \mathrm{g}^{-1}$ & 82 \\
\hline Lead monoxide & Uranium ions & $13.8 \mathrm{mg} \mathrm{g}^{-1}$ & 92 \\
\hline Beryllium oxide & Uranium ions & $17.6 \mathrm{mg} \mathrm{g}^{-1}$ & 92 \\
\hline Aluminium hydroxide & Uranium ions & $18.1 \mathrm{mg} \mathrm{g}^{-1}$ & 92 \\
\hline Barium sulfate & Uranium ions & $20.5 \mathrm{mg} \mathrm{g}^{-1}$ & 92 \\
\hline Manganese dioxide & Uranium ions & $20.7 \mathrm{mg} \mathrm{g}^{-1}$ & 92 \\
\hline Zinc oxide & Uranium ions & $29.9 \mathrm{mg} \mathrm{g}^{-1}$ & 92 \\
\hline Ferric hydroxide & Uranium ions & $34.6 \mathrm{mg} \mathrm{g}^{-1}$ & 92 \\
\hline Magnesium oxide & Uranium ions & $45.0 \mathrm{mg} \mathrm{g}^{-1}$ & 92 \\
\hline Sepiolite & $U^{6+}$ & $34.61 \mathrm{mg} \mathrm{g}^{-1}$ & 93 \\
\hline ZeoAds - zeolite by-product mixed with Portland cement & $\mathrm{Zn}^{2+}$ & $12.85 \mathrm{mg} \mathrm{g}^{-1}$ & 84 \\
\hline Clinoptilolite & $\mathrm{Zn}^{2+}$ & $2.7 \mathrm{mg} \mathrm{g}^{-1}$ & 85 \\
\hline Chabazite & $\mathrm{Zn}^{2+}$ & $5.5 \mathrm{mg} \mathrm{g}^{-1}$ & 85 \\
\hline Natural zeolite & $\mathrm{Zn}^{2+}$ & $0.134 \mathrm{mmol} \mathrm{g}^{-1}$ & 86 \\
\hline Coal fly ash prepared zeolite $4 \mathrm{~A}$ treated with $\mathrm{NaCl}$ & $\mathrm{Zn}^{2+}$ & $40.38 \mathrm{mg} \mathrm{g}^{-1}$ & 87 \\
\hline Natural zeolite & $\mathrm{Zn}^{2+}$ & $2.21 \mathrm{mg} \mathrm{g}^{-1}$ & 88 \\
\hline
\end{tabular}

Owing to their well-known ion-exchange properties, zeolites have been examined intensely in this context of heavy metal extraction. Natural zeolites have demonstrated a high selectivity for certain metal ions. For example, the abundant zeolites clinoptilolite and chabazite both exhibit an exceptional capacity for the removal of lead cations ( $6.0 \mathrm{mg} \mathrm{g}^{-1}$ for both adsorbents). Chabazite also displays very favorable removal of $\mathrm{Cd}^{2+}$ and cobalt ions ( $6.7 \mathrm{mg} \mathrm{g}^{-1}$ and $5.8 \mathrm{mg} \mathrm{g}^{-1}$ respectively), a good ability for the removal of $\mathrm{Zn}^{2+}$ and copper ions (5.5 mg g-1 and $5.1 \mathrm{mg}^{-1}$ respectively), while only a poor propensity for the removal of chromium ions ( $3.6 \mathrm{mg} \mathrm{g}^{-1}$ ) was observed. ${ }^{85}$ The capability of zeolite to remove heavy metal ions can be improved by modifications of natural zeolites, or by using synthetic zeolites. A study by Ok et al. (2007) ${ }^{84}$ showed that a zeolite-portland cement composite material was able to remove lead, copper, $\mathrm{Zn}^{2+}$, and $\mathrm{Cd}^{2+}$ cations more effectively than activated carbon. Another report, by Pitcher et al. (2004), ${ }^{94}$ explored the use of synthetic and natural zeolites for the reduction of heavy metal ions from the drainage water of motorways. Even though synthetic zeolites were found to exhibit, generally, a better performance than natural zeolites, concerns about the use of syntheticzeolites were raised, owing to the undesirable ion-exchange-induced release of $\mathrm{Na}^{+}$, as well as on account of the rise in $\mathrm{pH}$ value to 8.5-9.0 upon introduction of the synthetic zeolite to either the synthetic solution or the stormwater used in the study, regardless of the initial $\mathrm{pH}$ of either solution.

Porous clays, such as montmorillonite, kaolinite, china clay, bentonite, and wollastonite can also be used for the removal of heavy metal ions from aqueous solutions. In 2009, Donat ${ }^{93}$ reported the ability of the natural magnesium hydrosilicate clay, sepiolite to adsorb $34.61 \mathrm{mg} \mathrm{g}^{-1}$ of $\mathrm{U}^{6+}$ ions, which allows the effective removal of these ions from wastewater. Several reviews have furthermore concluded that bentonite and montmorillonite generally exhibit the best performances, while kaolinite and wollastonite tend to not be very effective. $6,80,81$ Natural vermiculite also shows reasonable performance, with adsorption capacities of $26.0 \mathrm{mg} \mathrm{g}^{-1}$ for $\mathrm{Cu}^{2+}$ ions and $19.3 \mathrm{mg} \mathrm{g}^{-1}$ for $\mathrm{Ni}^{2+}$ ions. ${ }^{6}$ Interestingly, bespoke synthetic bentonite exceeds the performance of natural bentonite with respect to the adsorption of $\mathrm{Pb}^{2+}$ ions, with corresponding adsorption capacities of $6 \mathrm{mg}$ $\mathrm{g}^{-1}$ for natural bentonite versus $58 \mathrm{mg} \mathrm{g}^{-1}$ for the synthetic bentonite. Meanwhile, the adsorption capacity of $\mathrm{Cr}^{6+}$ ions remains 
virtually constant between the two bentonite materials ( $55 \mathrm{mg} \mathrm{g}^{-1}$ for natural, and $57 \mathrm{mg} \mathrm{g}^{-1}$ for synthetic). ${ }^{81}$ Unfortunately, the unfavorable ratio between the adsorption capacity of clays and their cost nonetheless decreases the prospects of clays in commercial applications of encapsulation relative to other adsorbents.

Several industrial waste products have been assessed as less cost-intensive adsorbents for the removal of heavy metal ions from aqueous solutions (see Table 2). These waste products include red mud (a by-product of the aluminium production), green sands (an iron foundry by-product), blast-furnace slag from the steel industry, iron/steel slag, magnetite, and fly ash . ${ }^{6}$ Red mud and blast-furnace slag exhibit adsorption capacities of more than $100 \mathrm{mg} \mathrm{g}^{-1}$ for certain metal ions, such as $\mathrm{Ni}^{2+}, \mathrm{Cu}^{2+}$, and $\mathrm{Zn}^{2+}$, while green sand, iron/steel slag, and magnetite also perform fairly well with adsorption capacities ranging ca. $15-95 \mathrm{mg}$ $\mathrm{g}^{-1}{ }^{6}$ In contrast, fly ash is generally considered unsuitable for the removal of heavy metal ions from water samples, having adsorption capacities to only ca. $2 \mathrm{mg} \mathrm{g}^{-1}{ }^{16}$ yet, one study reported the use of coal fly ash for the preparation of synthetic zeolite $4 \mathrm{~A}$ for the removal of $\mathrm{Co}^{2+}, \mathrm{Cr}^{3+}, \mathrm{Cu}^{2+}, \mathrm{Zn}^{2+}$, and $\mathrm{Ni}^{2+}$ ions from aqueous solutions. ${ }^{87}$ Those results showed a strong dependence of the adsorption properties on the $\mathrm{pH}$ value, but otherwise this synthetic zeolite exhibited comparable adsorption capacities to its naturally occurring analog. Hence, under specific circumstances, fly ash may be a useful and more cost-effective alternative to activated carbon for the removal of heavy metal ions from wastewater.

Metal oxides and nanomaterials represent another alternative for the removal of heavy metal ions from water samples. In 1975, Dai and Wu ${ }^{92}$ compiled the results of 300-400 adsorbents, including alkaline earth oxides, hydroxides, and sulfates, which were tested for the removal or uranium ions from dilute aqueous solutions. The best of these adsorbents were found to be magnesium oxide (adsorption capacity $45.0 \mathrm{mg} \mathrm{g}^{-1}$ ), ferric hydroxide (34.6 $\left.\mathrm{mg} \mathrm{g}^{-1}\right)$, zinc oxide (29.9 $\mathrm{mg} \mathrm{g}^{-1}$ ), manganese dioxide $\left(20.7 \mathrm{mg} \mathrm{g}^{-1}\right)$, and barium sulfate $\left(20.5 \mathrm{mg} \mathrm{g}^{-1}\right)$. The authors furthermore discovered that the adsorption capacity could be improved ( $\leq 112 \mathrm{mg} \mathrm{g}^{-1}$ ) by using a 1:3:4 mixture of aluminium hydroxide, ferric hydroxide, and activated carbon. A review on low-cost adsorbents by Babel and Kurniawan $(2003)^{80}$ confirmed the potential suitability of iron oxide, particularly when coated with sand. Hua et al. (2012) 5 exclusively reviewed nano-sized materials for the removal of heavy metal ions from water samples, which included ferric oxide, manganese oxide, alumina oxide, titanium oxide, magnesium oxide, zinc oxide, and cerium oxide. Nano-sized ferric oxide showed an excellent removal for $\mathrm{Cu}^{2+}$ ions $\left(>100 \mathrm{mg} \mathrm{g}^{-1}\right)$, and a good removal capacity for $\mathrm{Ni}^{2+}$ ions $(\leq 23.6$ $\mathrm{mg} \mathrm{g}^{-1}$ ) and $\mathrm{Cr}^{6+}$ ions ( $\leq 19.2 \mathrm{mg} \mathrm{g}^{-1}$ ), whereby the observed adsorption capacity toward $\mathrm{Cr}^{6+}$ ions was higher than that for activated carbon (15.47 $\mathrm{mg} \mathrm{g}^{-1}$ ). Traditionally, nano-sized alumina oxides have been used predominantly for the removal of heavy metal ions from aqueous samples, since they exhibit a high adsorption capacity for $\mathrm{Cr}^{6+}\left(100.0 \mathrm{mg} \mathrm{g}^{-1}\right), \mathrm{Pb}^{2+}\left(100.0 \mathrm{mg} \mathrm{g}^{-1}\right)$, and Cd${ }^{2+}$ (83.33 $\left.\mathrm{mg} \mathrm{g}^{-1}\right)$ ions. Nano-sized Cryptomelane-type $\left(\mathrm{K}^{+}\right)$manganese oxides were particularly effective for the removal of trace amounts of $\mathrm{Ag}^{+}$ions, and together with Todorokite-type $\left(\mathrm{Mg}^{2+}\right.$ and $\left.\mathrm{Ca}^{2+}\right)$ manganese oxides they demonstrated selective adsorption of $\mathrm{Cu}^{2+}\left(\leq 0.9-1.3 \mathrm{mmol} \mathrm{g}{ }^{-1}\right), \mathrm{Ni}^{2+}$, and $\mathrm{Cd}^{2+}$ ions. Other manganese oxides, such as $\mathrm{H}_{1.6} \mathrm{Mn}_{1.6} \mathrm{O}_{4}$ were tested for the recovery of $\mathrm{Li}^{+}$ions from seawater (adsorption capacity: $40 \mathrm{mg} \mathrm{g}^{-1}$ ). Nano-sized titanium oxides showed promise in their ability to simultaneously remove multiple metal ions such as $\mathrm{Zn}^{2+}, \mathrm{Cd}^{2+}$, lead, nickel, and copper simultaneously, with reasonable capacities for $\mathrm{Zn}^{2+}\left(15.3 \mathrm{mg} \mathrm{g}^{-1}\right)$ and $\mathrm{Cd}^{2+}\left(7.9 \mathrm{mg} \mathrm{g}^{-1}\right)$. For some of the oxides, a correlation between the nature of their particulate structure and the adsorption capacity was observed. For example, a study on nano-sized magnesium oxide showed that their adsorption capacity toward $\mathrm{Cr}^{6+}$ is highest for nanoflakes $\left(15.2 \mathrm{mg} \mathrm{g}^{-1}\right.$ ) or for mesoporous microspheres composed of nanoflakes (19.8 mg g-1 $) .5$ Hollow ceria nanospheres composed of $\sim 14 \mathrm{~nm} \mathrm{CeO} 2$ nanocrystals also showed promising removal capacities toward $\mathrm{Cr}^{6+}\left(15.4 \mathrm{mg} \mathrm{g}^{-1}\right)$, and $\mathrm{Pb}^{2+}$ ions $\left(9.2 \mathrm{mg} \mathrm{g}^{-1}\right)$; the corresponding capacity values for the bulk material were nearly 70 times lower than that of the hollow nanospheres. ${ }^{5}$ Studies on zinc oxide nanosheets, a material that is predominantly used to capture $\mathrm{H}_{2} \mathrm{~S}$, showed good adsorption capacity values toward $\mathrm{Pb}^{2+}$ ions $\left(6.7 \mathrm{mg} \mathrm{g}^{-1}\right)$, as well as an impressive adsorption capacity toward $\mathrm{Cu}^{2+}$ ions $\left(>1600 \mathrm{mg} \mathrm{g}^{-1}\right.$ ). A study on nanostructured calcium silicate ${ }^{95}$ showed effective $\mathrm{Cu}^{2+}$ ion removal from dilute aqueous solutions; however, both the removal mechanisms and the capacity values varied depending on the source of the $\mathrm{Cu}^{2+}$ ions. For calcium silicate $\mathrm{B}$, the $\mathrm{Cu}^{2+}$ ion uptake after 30 minutes was $0.082 \mathrm{mg} \mathrm{g}^{-1}$ from $\mathrm{Cu}\left(\mathrm{NO}_{3}\right)_{2}$, while the uptake from $\mathrm{CuCl} 2$ was 0.077 $\mathrm{mg} \mathrm{g}^{-1}$.

2.3 Removal of other pollutants from aqueous solution. Apart from dyes and heavy metal ions, a great variety of other pollutants may be found in wastewater. For example, phosphates are well known for their adverse environmental effects. Huang et al. (2008) ${ }^{91}$ targeted the removal of phosphates using raw and activated red muds as the adsorption agent. Several activation strategies were tested, which revealed that acid, or acid with heat pre-treatments afforded the best results. In particular, a pretreatment with $\mathrm{HCl}$ increased the adsorption capacity of raw red mud from $0.23 \mathrm{mg} \mathrm{g}^{-1}$ to $0.58 \mathrm{mg} \mathrm{g}^{-1}$. Chubar et al. (2005) ${ }^{90}$ 
examined a series of inorganicion exchange materials based on the oxides of zirconium, iron, and aluminum with respect to their capacity to adsorb phosphates. The selected adsorbents $\mathrm{ZrO}_{2} \cdot \mathrm{xH}_{2} \mathrm{O}\left(\leq 47.62 \mathrm{mg} \mathrm{g}{ }^{-1}\right), \mathrm{Fe}_{2} \mathrm{O}_{3} \cdot 2 \mathrm{Al}_{2} \mathrm{O}_{3} \cdot \mathrm{xH}_{2} \mathrm{O}\left(\leq 20.8 \mathrm{mg} \mathrm{g}^{-1}\right)$, and $\mathrm{Fe}_{2} \mathrm{O}_{3} \cdot \mathrm{Al}_{2} \mathrm{O}_{3} \cdot x \mathrm{H}_{2} \mathrm{O}\left(\leq 22.9 \mathrm{mg} \mathrm{g}^{-1}\right)$ all demonstrated a propensity toward the removal of phosphates.

The removal of arsenic- and selenium-based compounds (as opposed to heavy-metal ions) is also of significant concern, given their adverse effects of especially the former on human health. Szlachta et al. (2012) ${ }^{82}$ investigated crystalline $\mathrm{MnCO}_{3}$ and $\mathrm{Mn}^{3+}$ hydrous oxides, as well as $\mathrm{\gamma}^{-} \mathrm{Fe}_{2} \mathrm{O}_{3}$ and amorphous $\mathrm{Fe}^{3+}$ hydrous oxides for the removal of arsenic- and selenium-based compounds from wastewater. All of these adsorbents exhibited high selectivity for both pollutants, with maximum adsorption capacities of $47.6 \mathrm{mg} \mathrm{g}^{-1}$ (arsenite) and $29.0 \mathrm{mg} \mathrm{g}^{-1}$ (selenite). Mohan and Pittman (2007) 22 specifically reviewed adsorbents for the removal of arsenic from wastewater, covering its various oxidation states and environmental forms. Conventionally, iron or iron salts, such as iron oxides, hydroxides, and oxyhydroxides, are the most widely used materials for the removal of arsenicbased compounds from wastewater since they combine high efficiency with low cost. However, as these adsorbing agents cannot be regenerated and, moreover, exhibit their highest efficiency only at low pH values, the development of better alternatives remains a key research target. Such alternatives may include clays, silica, sands, and activated alumina. Even though efficiency towards the removal of arsenic- and selenium-based compounds is relatively low (typical capacities $\leq 5 \mathrm{mg} \mathrm{g}^{-1}$ ), ${ }^{22} \mathrm{clays}$, silica, and sands are interesting with respect to their low cost and abundance. Conversely, activated alumina is highly efficient and can be regenerated in situ, but in order to remove aresenites efficiently, these required a pre-oxidation treatment to form arsenates. Furthermore, in common with the aforementioned iron compounds, activated alumina adsorbing agents operate best at low $\mathrm{pH}$ values.

For all studies involving the removal of pollutants from wastewater, several important parameters have to be taken into account when comparing efficiencies. Given the versatile nature of the task at hand, a great number of variables must be considered. Accordingly, individual studies as well as reviews point out that the efficiency of the adsorbent under investigation will be affected by variations in $\mathrm{pH}$ value, concentrations of adsorbates and adsorbents, the presence of competing adsorbates, temperature, and pre-treatment methods. Furthermore, some studies even show that the nature and design of the experiment, e.g. batch or column studies, can also have a significant effect on the observed adsorption capacity. It is therefore not surprising that very few studies report all salient variables, rendering comparisons between adsorbents tricky at best. Therefore, the results summarized here should be taken as general guidelines when searching for an adsorbent for a particular use.

\section{The removal of airborne pollutants}

Airborne pollutants, originating from power plants, industrial sources, or transportation, contribute heavily to climate change. Greenhouse gas emissions resulting from the combustion of fossil fuels in power plants or vehicles are particularly dangerous, and efforts to minimize the quantities of harmful materials released represent an ongoing focus of the scientific community. Methods to remove such harmful materials from the atmosphere include cryogenic distillation, ${ }^{9}$ membrane purification, ${ }^{4,9,96}$ catalysis, ${ }^{4,97-99}$ adsorption by liquids, 9,100 adsorption by solids, 4,9,10,96,100,101 condensation, ${ }^{4,96}$ and oxidation. ${ }^{4,96}$

3.1 The removal of $\mathrm{CO}_{2}$ from gas streams. Since the industrial revolution, levels of atmospheric $\mathrm{CO}_{2}$ have risen by $35 \%,{ }^{9}$ and this rise has been connected to climate change. Environmental concerns have since spurred intense investigation and legislative regulation in order to control and reduce $\mathrm{CO}_{2}$ emissions. Yet, given the ever-increasing global demand for energy, an immediate halt in $\mathrm{CO}_{2}$ emissions is unrealistic. Flue gas emissions from power plants account for $\sim 44 \%$ of anthropogenic $\mathrm{CO}_{2}$ emissions from the combustion of fossil fuels such as coal, oil, and natural gas. ${ }^{26}$ Several means of filtering $\mathrm{CO}_{2}$ from the thus produced emissions exist, whereby amine- $\mathrm{CO}_{2}$ chemistry is usually employed in gas-liquid adsorption columns. However, such columns generally suffer from corrosion, a high input of energy, and problems associated with viscosity and foaming. ${ }^{100}$ Considering these issues and the intrinsically complicated composition of flue gases, which are predominantly based on water vapor, in connection with the encountered high temperatures $\left(T>650 \mathrm{~K}\right.$ ), research efforts remain concentrated on the development of better $\mathrm{CO}_{2}$ filtration methods and materials. Such investigations currently focus on solid-state adsorbents as more durable alternatives to aminebased scrubs. Adsorbents that have been investigated for the capture of $\mathrm{CO}_{2}$, together with their corresponding adsorption capacities, are shown in Table 3. 
Table 3. Reported inorganic adsorbents used to encapsulate $\mathrm{CO}_{2}$ together with their adsorption capacity performance metrics. * indicates where values either could not be obtained, or were not specified (eg. presented as a range)

\begin{tabular}{|c|c|c|c|c|}
\hline Adsorbent & $\begin{array}{l}\text { Maximum Reported } \\
\text { Capacity }\end{array}$ & Temperature & Pressure & Ref. \\
\hline $\mathrm{AlPO}_{4}-5$ & ca. $0.42 \mathrm{mmol} \mathrm{g}^{-1}$ & $303 \mathrm{~K}$ & ca. $450 \mathrm{kPa}$ & 102 \\
\hline Basic alumina & $1.005 \mathrm{mmol} \mathrm{g}^{-1}$ & $293 \mathrm{~K}$ & $99.7 \mathrm{kPa}$ & 103 \\
\hline Amine-loaded MCM-41 & $1.26 \mathrm{mmol} \mathrm{g}^{-1}$ & $298 \mathrm{~K}$ & $<15.20 \mathrm{kPa}$ & 100 \\
\hline Amine-loaded pore-expanded MCM-41 & $2.36 \mathrm{mmol} \mathrm{g}^{-1}$ & $298 \mathrm{~K}$ & $<15.20 \mathrm{kPa}$ & 100 \\
\hline Amine-loaded silica gel & $1.88 \mathrm{mmol} \mathrm{g}^{-1}$ & $298 \mathrm{~K}$ & $<15.20 \mathrm{kPa}$ & 100 \\
\hline PEI-loaded MCM-41 & $133 \mathrm{mg} \mathrm{g}^{-1}$ & $348 \mathrm{~K}$ & $101.3 \mathrm{kPa}$ & 104 \\
\hline PEI-loaded mesocellular foam silica & $192.6 \mathrm{mg} \mathrm{g}^{-1}$ & $348 \mathrm{~K}$ & $101.3 \mathrm{kPa}$ & 105 \\
\hline PEI-loaded SBA-15 & $116.4 \mathrm{mg} \mathrm{g}^{-1}$ & $348 \mathrm{~K}$ & $101.3 \mathrm{kPa}$ & 105 \\
\hline High-concentration-amine-funtionalised SBA-15 & ca. $1.1 \mathrm{mmol} \mathrm{g}^{-1}$ & $298 \mathrm{~K}$ & $10.13 \mathrm{kPa}$ & 106 \\
\hline Medium-concentration-amine-funtionalised SBA-15 & ca. $0.7 \mathrm{mmol} \mathrm{g}^{-1}$ & $298 \mathrm{~K}$ & $10.13 \mathrm{kPa}$ & 106 \\
\hline Low-concentration-amine-funtionalised SBA-15 & ca. $0.2 \mathrm{mmol} \mathrm{g}^{-1}$ & $298 \mathrm{~K}$ & $10.13 \mathrm{kPa}$ & 106 \\
\hline Ca-exchanged clinoptilolite & ca. $2 \mathrm{mmol} \mathrm{g}^{-1}$ & $*$ & $60 \mathrm{kPa}$ & 107 \\
\hline K-exchanged clinoptilolite & ca. $1.5 \mathrm{mmol} \mathrm{g}^{-1}$ & * & $60 \mathrm{kPa}$ & 107 \\
\hline Na-exchanged clinoptilolite & ca. $1.2 \mathrm{mmol} \mathrm{g}^{-1}$ & * & $60 \mathrm{kPa}$ & 107 \\
\hline Natural clinoptilolite-rich volcanictuff & ca. $1.7 \mathrm{mmol} \mathrm{g}^{-1}$ & * & $60 \mathrm{kPa}$ & 107 \\
\hline Zeolite $13 \mathrm{X}$ & ca. $2.5 \mathrm{mmol} \mathrm{g}^{-1}$ & $298 \mathrm{~K}$ & $10.13 \mathrm{kPa}$ & 106 \\
\hline Zeolite 13X & $7.372 \mathrm{mmol} \mathrm{g}^{-1}$ & $298 \mathrm{~K}$ & $3200 \mathrm{kPa}$ & 108 \\
\hline Zeolite 13X & ca. $1.2 \mathrm{mmol} \mathrm{g}^{-1}$ & $323 \mathrm{~K}$ & ca. $58 \mathrm{kPa}$ & 97 \\
\hline Zeolite 13X & $22.0 w t \%$ & RT & $0.67 \mathrm{kPa}$ & 109 \\
\hline Zeolite 4A & 5.1 wt\% & RT & $0.67 \mathrm{kPa}$ & 109 \\
\hline Zeolite 5A & ca. $1.2 \mathrm{mmol} \mathrm{g}^{-1}$ & $323 \mathrm{~K}$ & ca. $65 \mathrm{kPa}$ & 97 \\
\hline MCM-41 & $14.3 \mathrm{mg} \mathrm{g}^{-1}$ & $323 \mathrm{~K}$ & $101.3 \mathrm{kPa}$ & 104 \\
\hline MCM-41 & ca. $2.0 \mathrm{mmol} \mathrm{g}^{-1}$ & $303 \mathrm{~K}$ & ca. $1125 \mathrm{kPa}$ & 102 \\
\hline Mesocellular foam silica & $10.6 \mathrm{mg} \mathrm{g}^{-1}$ & $348 \mathrm{~K}$ & $101.3 \mathrm{kPa}$ & 105 \\
\hline Silicate & $3.296 \mathrm{mmol} \mathrm{g}^{-1}$ & $276.8 \mathrm{~K}$ & $2001.19 \mathrm{kPa}$ & 110 \\
\hline SBA-15 & $23.5 \mathrm{mg} \mathrm{g}^{-1}$ & $348 \mathrm{~K}$ & $101.3 \mathrm{kPa}$ & 105 \\
\hline $\mathrm{CaO} / \mathrm{Ca}_{12} \mathrm{Al}_{14} \mathrm{O}_{33}$ & $450 \mathrm{mg} \mathrm{g}^{-1}$ & $963 \mathrm{~K}$ & $*$ & 111 \\
\hline Ce-doped $\mathrm{CaO}$ & $44 \times 10^{4} \mathrm{mg} \mathrm{g}^{-1}$ & $1023 \mathrm{~K}$ & $100 \mathrm{kPa}$ & 112 \\
\hline Co-doped CaO & $26 \times 10^{4} \mathrm{mg} \mathrm{g}^{-1}$ & $1023 \mathrm{~K}$ & $100 \mathrm{kPa}$ & 112 \\
\hline $\mathrm{Cr}$-doped $\mathrm{CaO}$ & $40 \times 10^{4} \mathrm{mg} \mathrm{g}^{-1}$ & $1023 \mathrm{~K}$ & $100 \mathrm{kPa}$ & 112 \\
\hline Cu-doped CaO & $24 \times 10^{4} \mathrm{mg} \mathrm{g}^{-1}$ & $1023 \mathrm{~K}$ & $100 \mathrm{kPa}$ & 112 \\
\hline $\mathrm{Mn}$-doped $\mathrm{CaO}$ & $47 \times 10^{4} \mathrm{mg} \mathrm{g}^{-1}$ & $1023 \mathrm{~K}$ & $100 \mathrm{kPa}$ & 112 \\
\hline $\mathrm{MgO} / \mathrm{CaO}-$ loaded porous carbon & $26.5 \mathrm{mg} \mathrm{g}^{-1}$ & $293 \mathrm{~K}$ & $*$ & 113 \\
\hline $\mathrm{K}_{2} \mathrm{CO}_{3}$-modified $\mathrm{Li}_{2} \mathrm{ZrO}_{3}$ & $23 w t \%$ & $673 \mathrm{~K}$ & $101.3 \mathrm{kPa}$ & 114 \\
\hline $\mathrm{Li}_{2} \mathrm{ZrO}_{3}$ & $29 w t \%$ & $773 \mathrm{~K}$ & $101.3 \mathrm{kPa}$ & 114 \\
\hline Na-doped lithium zirconate nano squares & 20 wt\% & $923 \mathrm{~K}$ & $*$ & 115 \\
\hline Zr-pillared clay from Benavila-Alentejo & ca. $2.7 \mathrm{mmol} \mathrm{g}^{-1}$ & $215 \mathrm{~K}$ & $100 \mathrm{kPa}$ & 116 \\
\hline Zr-pillared clay from Porto Santo-Madeira & ca. $2.6 \mathrm{mmol} \mathrm{g}^{-1}$ & $215 \mathrm{~K}$ & $100 \mathrm{kPa}$ & 116 \\
\hline
\end{tabular}

For gas separation purposes, zeolites have been studied extensively, and several reviews on $\mathrm{CO}_{2}$ capture include zeolites. ${ }^{8,9,26}$ In general, these conclude that the use of zeolites for such purposes is possible, but that the performance depends strongly on the experimental processing conditions. Overall, their adsorption capacity for $\mathrm{CO}_{2}$ is higher than that of $\mathrm{N}_{2}$ or $\mathrm{CH}_{4}$, but in applications for the separation of flue gas, their adsorption sites receive strong competition from $\mathrm{H}_{2} \mathrm{O}$ adsorption. ${ }^{107,108,117}$ Furthermore, zeolite adsorbents operate best at relatively low temperatures $(T<373 \mathrm{~K}$ ), whereas many applications, such as the separation of flue gas, are carried out at higher temperatures $(T \geq 573 \mathrm{~K}) .{ }^{9,26}$ Moreover, several reports demonstrate that zeolites exhibit better performance at elevated pressures, ${ }^{106,108}$ and that their performance can be further improved by pre-treatment (typically either acid or alkali washing), fine-tuning of the cation exchange, or by combining the zeolite with an amine.8,9,100,104,107 
Another important consideration of gas adsorption process control is the regeneration stability of the adsorbent. In this respect, zeolites also fair well, typically exhibiting better performance metrics than other inorganic adsorbents. In particular, alkali and alkali earth oxides have shown much promise, especially calcium- and lithium-based oxides. ${ }^{9,26,111}$ These materials have generated considerable interest on account of their high $\mathrm{CO}_{2}$ selectivity, as well as their high thermal stability ( $\left.\mathrm{T}>673 \mathrm{~K}\right) .{ }^{26}$ Calcium oxides undergo chemical reactions that are generally regarded as effective for high-temperature in situ removal of $\mathrm{CO}_{2} .{ }^{9}$ In addition, calcium oxides are relatively cheap and highly abundant, since they are the main components in limestone and dolomite. Their regeneration, however, is nontrivial, since calcium oxides are subject to rapid degradation. ${ }^{9}$ Lithium zirconates have garnered much interest as potentially promising alternatives. ${ }^{26,114,115}$ They exhibit reasonable adsorption capacities $(\leq 20$ wt\%), which are retained at high temperatures ( $\mathrm{T}>673 \mathrm{~K}$ ), and they also demonstrate good thermal stability. Moreover, their regeneration is better than that of calcium oxides, even though kinetic limitations render adsorption rates too slow for commercial applications. ${ }^{26}$ Magnesium-based oxides were investigated as medium-temperature $(T=473-673 \mathrm{~K})$ adsorbents with low regeneration energy requirements. However, in common with calcium oxides, regeneration stability is poor, and the Mgbased oxides only display moderate $\mathrm{CO}_{2}$ adsorption capacities $\left(\leq 2.36 \mathrm{mmol} \mathrm{g}^{-1}\right)$, which diminish further with increasing temperature. ${ }^{9}$ Yong et al. (2000) ${ }^{103}$ investigated the adsorption capacity of two types of basic alumina adsorbents and observed values greater than $0.30 \mathrm{mmol} \mathrm{g}^{-1}$ at $573 \mathrm{~K}$. Based on these results, the authors concluded that basic alumina could be used directly as adsorbents for $\mathrm{CO}_{2}$ from power-plant flue gases.

Several other inorganic materials for $\mathrm{CO}_{2}$ capture appear in the scientificliterature. Anionic clays such as hydrotalcitetype compounds have been investigated, even though their adsorption capacity is typically lower than that of other adsorbents, and they may be subject to structural change at high temperatures. ${ }^{9}$ Nevertheless, these materials may potentially be used on wet flue gas streams on account of the favorable influence of water on their adsorption capacity. Regeneration is possible, although it strongly depends on the method applied. ${ }^{9}$ Other inorganic materials have been investigated, predominantly as possible support materials for amines. For example, Zhao et al. (2012) ${ }^{105}$ used siliceous mesocellular foam (MCF) particles as a support material for polyethylenimine (PEI) to improve $\mathrm{CO}_{2}$ capture. The authors reported a high adsorption capacity $(\leq 362 \mathrm{mg}$ $\mathrm{g}^{-1}$ ) and the resulting particles are comparable to the most effective adsorbents reported so far.

3.2 The removal of volatile organic compounds (VOCs), nitrogen oxides $\left(\mathrm{NO}_{\mathrm{x}}\right.$ ), and sulfur oxides ( $\mathrm{SO}_{\mathrm{x}}$ ) from gas streams. Flue gas streams, in particular those from the combustion of fossil fuels, contain gases besides $\mathrm{CO}_{2}$ : nitrogen-based oxides ( $\mathrm{NO}_{\mathrm{x}}$ ), sulfur-based oxides $\left(\mathrm{SO}_{\mathrm{x}}\right.$ ), as well as volatile organic compounds (VOCs) such as chlorohydrocarbons, perfluorocarbons, tetrachloroethane, methane, ethane, and acetone. A structured list of commonly encountered VOCs has been compiled by Khan and Ghoshal (2000). ${ }^{4}$ The combustion of fossil fuels accounts for $~ 5 \%$ of the global release of VOCs, ${ }^{118}$ and for $65 \%$ of the release of $\mathrm{SO}_{x}{ }^{119}$ In China, the combustion of coal is responsible for $87 \%, 67 \%$, and $71 \%$ of the country's emissions of $\mathrm{SO}_{2}, \mathrm{NO}_{x}$, and $\mathrm{CO}_{2}$, respectively. ${ }^{97}$ Many VOCs are toxic or carcinogenic and certain VOCs may also contribute to the retardation of planetary heat loss, while others become even more harmful upon reaction with $\mathrm{NO}_{x}$ or $\mathrm{SO}_{x}$ to produce photochemical smog, which can contribute to ozone depletion. In turn, $\mathrm{NO}_{x}$ and $\mathrm{SO}_{x}$ are harmful since they constitute the primary components in acid rain. As such, these compounds are among the most dangerous contributors to air pollution.

Gas removal methods via adsorption onto solids are typically based on activated carbon, even though regeneration is difficult for this adsorbent, thermal instability poses fire risks, pore clogging may occur, and hygroscopicity must be considered. ${ }^{96,118,120-124}$ Reported adsorption capacities of a variety of adsorbents investigated for VOCs, NO encapsulation are listed in Table 4.

Table 4. Reported inorganic adsorbents used to encapsulate VOCs, as well as $\mathrm{SO}_{\mathrm{x}}$ and $\mathrm{NO}_{\mathrm{x}}$ adsorbates together with their adsorption capacity performance metrics.

\begin{tabular}{llll}
\hline Adsorbent & Adsorbate & Maximum Reported Capacity & Ref. \\
\hline Dealuminated faujasite & 1,2-dichloroethane (DCA) & $269 \mathrm{mg} \mathrm{g}^{-1}$ & 122 \\
Unmodified MCM-41 & benzene & ca. $700 \mathrm{mg} \mathrm{g}^{-1}$ & 124 \\
Modified MCM-41 & benzene & ca. $500 \mathrm{mg} \mathrm{g}^{-1}$ & 124 \\
Hydrophobic zeolite Y & benzene & ca. $300 \mathrm{mg} \mathrm{g}^{-1}$ & 124 \\
\hline
\end{tabular}




\begin{tabular}{|c|c|c|c|}
\hline MCM-41 & Carbon tetrachloride & ca. $1100 \mathrm{mg} \mathrm{g}^{-1}$ & 124 \\
\hline Hydrophobic zeolite Y & Carbon tetrachloride & ca. $500 \mathrm{mg} \mathrm{g}^{-1}$ & 124 \\
\hline Silicalite-1 & Carbon tetrachloride & ca. $50 \mathrm{mg} \mathrm{g}^{-1}$ & 124 \\
\hline Dealuminated faujasite & Dichloromethane (DCM) & $310 \mathrm{mg} \mathrm{g}^{-1}$ & 122 \\
\hline MCM-41 & $n$-hexane & ca. $600 \mathrm{mg} \mathrm{g}^{-1}$ & 124 \\
\hline Hydrophobic zeolite Y & $n$-hexane & ca. $200 \mathrm{mg} \mathrm{g}^{-1}$ & 124 \\
\hline Silicalite-1 & $n$-hexane & ca. $100 \mathrm{mg} \mathrm{g}^{-1}$ & 124 \\
\hline Zeolite $13 \mathrm{X}$ & NO & ca. $0.125 \mathrm{mmol} \mathrm{g}^{-1}$ & 97 \\
\hline Zeolite 5A & NO & ca. $0.125 \mathrm{mmol} \mathrm{g}^{-1}$ & 97 \\
\hline $\mathrm{NaY}$ & NO & $0.0621 \mathrm{mmol} \mathrm{g}^{-1}$ & 125 \\
\hline $\mathrm{NaX}$ & NO & $0.1581 \mathrm{mmol} \mathrm{g}^{-1}$ & 125 \\
\hline $\mathrm{CaA}$ & NO & $0.1644 \mathrm{mmol} \mathrm{g}^{-1}$ & 125 \\
\hline $\mathrm{CeO}_{2}$ & $\mathrm{NO}_{2}$ & $20 \mathrm{mg} \mathrm{g}^{-1}$ & 126 \\
\hline $\mathrm{Ce}_{0.8} \mathrm{Zr}_{0.2} \mathrm{O}_{2}$ & $\mathrm{NO}_{2}$ & $30 \mathrm{mg} \mathrm{g}^{-1}$ & 126 \\
\hline $\mathrm{Ce}_{0.6} \mathrm{Zr}_{0.4} \mathrm{O}_{2}$ & $\mathrm{NO}_{2}$ & $26 \mathrm{mg} \mathrm{g}^{-1}$ & 126 \\
\hline $\mathrm{Ce}_{0.4} \mathrm{Zr}_{0.6} \mathrm{O}_{2}$ & $\mathrm{NO}_{2}$ & $22 \mathrm{mg} \mathrm{g}^{-1}$ & 126 \\
\hline $\mathrm{Ce}_{0.2} \mathrm{Zr}_{0.8} \mathrm{O}_{2}$ & $\mathrm{NO}_{2}$ & $40 \mathrm{mg} \mathrm{g}^{-1}$ & 126 \\
\hline $\mathrm{Zr}(\mathrm{OH})_{4}$ & $\mathrm{NO}_{2}$ & $16 \mathrm{mg} \mathrm{g}^{-1}$ & 126 \\
\hline $\mathrm{MgAlFe}$ & $\mathrm{SO}_{2}$ & $1460 \mathrm{mg} \mathrm{g}^{-1}$ & 119 \\
\hline $\mathrm{Cu} / \mathrm{MgAlFe}$ & $\mathrm{SO}_{2}$ & $1600 \mathrm{mg} \mathrm{g}^{-1}$ & 119 \\
\hline MgAIFeCu-1 & $\mathrm{SO}_{2}$ & $1570 \mathrm{mg} \mathrm{g}^{-1}$ & 119 \\
\hline MgAIFeCu-2 & $\mathrm{SO}_{2}$ & $1690 \mathrm{mg} \mathrm{g}^{-1}$ & 119 \\
\hline $\mathrm{MgO} / \mathrm{CaO}$-loaded porous carbon & $\mathrm{SO}_{2}$ & $59.6 \mathrm{mg} \mathrm{g}^{-1}$ & 113 \\
\hline Zeolite 13X & $\mathrm{SO}_{2}$ & ca. $2.7 \mathrm{mmol} \mathrm{g}^{-1}$ & 97 \\
\hline Zeolite 5A & $\mathrm{SO}_{2}$ & ca. $1.7 \mathrm{mmol} \mathrm{g}^{-1}$ & 97 \\
\hline Natural clinoptilolite & $\mathrm{SO}_{2}$ & $0.725 \mathrm{mmol} \mathrm{g}^{-1}$ & 127 \\
\hline H-clinoptilolite & $\mathrm{SO}_{2}$ & $0.791 \mathrm{mmol} \mathrm{g}^{-1}$ & 127 \\
\hline Na-exchanged clinoptilolite & $\mathrm{SO}_{2}$ & $0.989 \mathrm{mmol} \mathrm{g}^{-1}$ & 127 \\
\hline K-exchanged clinoptilolite & $\mathrm{SO}_{2}$ & $0.765 \mathrm{mmol} \mathrm{g}^{-1}$ & 127 \\
\hline Ca-exchanged clinoptilolite & $\mathrm{SO}_{2}$ & $0.714 \mathrm{mmol} \mathrm{g}^{-1}$ & 127 \\
\hline Li-exchanged clinoptilolite & $\mathrm{SO}_{2}$ & $0.892 \mathrm{mmol} \mathrm{g}^{-1}$ & 127 \\
\hline Ag-exchanged clinoptilolite & $\mathrm{SO}_{2}$ & $0.710 \mathrm{mmol} \mathrm{g}^{-1}$ & 127 \\
\hline Cd-exchanged clinoptilolite & $\mathrm{SO}_{2}$ & $1.188 \mathrm{mmol} \mathrm{g}^{-1}$ & 127 \\
\hline Mn-exchanged clinoptilolite & $\mathrm{SO}_{2}$ & $1.322 \mathrm{mmol} \mathrm{g}^{-1}$ & 127 \\
\hline Cu-exchanged clinoptilolite & $\mathrm{SO}_{2}$ & $1.104 \mathrm{mmol} \mathrm{g}^{-1}$ & 127 \\
\hline Co-exchanged clinoptilolite & $\mathrm{SO}_{2}$ & $1.132 \mathrm{mmol} \mathrm{g}^{-1}$ & 127 \\
\hline Fe-exchanged clinoptilolite & $\mathrm{SO}_{2}$ & $0.719 \mathrm{mmol} \mathrm{g}^{-1}$ & 127 \\
\hline Zn-exchanged clinoptilolite & $\mathrm{SO}_{2}$ & $0.750 \mathrm{mmol} \mathrm{g}^{-1}$ & 127 \\
\hline Y zeolite & $\mathrm{SO}_{2}$ & ca. $200 \mathrm{mg} \mathrm{g}^{-1}$ & 101 \\
\hline $\mathrm{CeO}_{2}-\mathrm{MCM}-41$ & $\mathrm{SO}_{2}$ & $<10 \mathrm{mg} \mathrm{g}^{-1}$ & 128 \\
\hline $\mathrm{CuO} / \mathrm{CeO}_{2}-\mathrm{MCM}-41$ & $\mathrm{SO}_{2}$ & $15 \mathrm{mg} \mathrm{g}^{-1}$ & 128 \\
\hline $\mathrm{CuO} / \mathrm{LiCl}-\mathrm{MCM}-41$ & $\mathrm{SO}_{2}$ & $80 \mathrm{mg} \mathrm{g}^{-1}$ & 128 \\
\hline Li-doped MCM-41 & $\mathrm{SO}_{2}$ & $130 \mathrm{mg} \mathrm{g}^{-1}$ & 128 \\
\hline ZnH-EPM & $\mathrm{SO}_{2}$ & $58.6 \mathrm{mg} \mathrm{g}^{-1}$ & 129 \\
\hline ZnO-C-EPM & $\mathrm{SO}_{2}$ & $43.2 \mathrm{mg} \mathrm{g}^{-1}$ & 129 \\
\hline ZnGO-EPM-L & $\mathrm{SO}_{2}$ & $118 \mathrm{mg} \mathrm{g}^{-1}$ & 129 \\
\hline ZnGr-EPM-L & $\mathrm{SO}_{2}$ & $38.5 \mathrm{mg} \mathrm{g}^{-1}$ & 129 \\
\hline Zeolite synthesized from fly ash & $\mathrm{SO}_{2}$ & $6.6 \mathrm{mg} \mathrm{g}^{-1}$ & 130 \\
\hline $\mathrm{NaY}$ & $\mathrm{SO}_{2}$ & $5.398 \mathrm{mmol} \mathrm{g}^{-1}$ & 125 \\
\hline $\mathrm{NaX}$ & $\mathrm{SO}_{2}$ & $6.473 \mathrm{mmol} \mathrm{g}^{-1}$ & 125 \\
\hline $\mathrm{CaA}$ & $\mathrm{SO}_{2}$ & $2.125 \mathrm{mmol} \mathrm{g}^{-1}$ & 125 \\
\hline TEA-modified SBA-15 & $\mathrm{SO}_{2}$ & $177 \mathrm{mg} \mathrm{g}^{-1}$ & 131 \\
\hline Dealuminated faujasite & Tetrachloroethane & $347 \mathrm{mg} \mathrm{g}^{-1}$ & 122 \\
\hline Dealuminated faujasite & Trichloroethene & $306 \mathrm{mg} \mathrm{g}^{-1}$ & 122 \\
\hline
\end{tabular}

Adsorption of VOCs, $\mathrm{NO}_{x}$, and $\mathrm{SO}_{\mathrm{x}}$ gases onto inorganic solids is mostly focused on zeolites, which are often considered to be a more robust alternative to activated carbon. For the removal of VOCs, activated carbon is still the most commonly used 
on account of its effectiveness and low cost. However, flammability and regeneration represent serious drawbacks, which may be circumvented by the use of zeolites, since these exhibit high thermal stability and can typically be regenerated easily. ${ }^{4} \mathrm{Many}$ different zeolites have been investigated for the removal of VOCs from gas streams, including faujasite-type, ${ }^{122,123,132} \mathrm{~A}$-type, ${ }^{96}$ and Y-type zeolites, ${ }^{120,124,133}$ as well as heulandite, ${ }^{134} \mathrm{MCM}-41,{ }^{118,124}$ and SBA-15. ${ }^{118}$ In general, the use of zeolites for the adsorption of VOCs is beneficial for dry gas streams, since zeolites are usually hydrophilic. Dealumination of zeolites, ${ }^{122-124,132}$ or the engineering of synthetic hydrophobic zeolites ${ }^{4,118,121,124}$ may improve their performance under "wet" conditions. A study by Clausse et al. (1998) ${ }^{122}$ revealed that dealuminated faujasite $Y$ demonstrates a high propensity for the adsorption of less volatile compounds, and so this adsorbent might be well suited for the removal of chlorinated $\mathrm{C}_{\mathrm{s}}$-VOC species such as tetrachloroethane.

For the removal of $\mathrm{NO}_{\mathrm{x}}$ and $\mathrm{SO}_{\mathrm{x}}$ gases, zeolite $\mathrm{X}$, zeolite $\mathrm{Y}$, and silicates represent the most widely evaluated zeolites. Some reports reveal good $\mathrm{SO}_{2}$ uptake for several zeolites, even though the presence of water may hinder adsorption. ${ }^{10,131,135}$ According to Zhi et al. (2011), ${ }^{131}$ treatment of mesoporous silica SBA-15 with triethanolamine resulted in the highly selective adsorption of $\mathrm{SO}_{2}$ when in the presence of high concentrations of $\mathrm{CO}_{2}$. Moreover, the authors concluded that the presence of water vapor had a positive effect on the adsorption capacity of $\mathrm{SO}_{2}$. Zeolites are also able to adsorb $\mathrm{NO}_{x}$ under certain conditions, and the adsorption of $\mathrm{NO}$ can be much weaker than that of $\mathrm{NO}_{2} \cdot{ }^{10,132}$ Most zeolites preferentially adsorb $\mathrm{NO}_{2}$ in the presence of $\mathrm{CO}_{2}$ whereby proton-type mordenite demonstrates the most promising results for the separation of $\mathrm{NO}_{2} / \mathrm{CO}_{2}$ mixtures. ${ }^{136}$

Metal-oxides such as alumina, calcium-based adsorbents, and zirconium hydroxides have also been investigated for the removal of pollutants from gas streams. Even though alumina does not exhibit a particularly favorable adsorption of VOCs, it still adsorbs dioxin better than pillared clays and zeolites. ${ }^{133}$ Calcium-based adsorbents such as lime, limestone, and dolomite exhibit a preference for $\mathrm{SO}_{2}$ in $\mathrm{CO}_{2} / \mathrm{SO}_{2}$ separation studies, and also show improved $\mathrm{CO}_{2}$ adsorption in the presence of water, since the competition for sites decreases the adsorption capacity of $\mathrm{SO}_{2}$ by around $20 \% .{ }^{10}$ These results suggest that calcium-based adsorbents should be ideally suited for the removal of $\mathrm{SO}_{2}$ under dry conditions. This study also showed that zirconium hydroxides hold promise for the removal of $\mathrm{SO}_{x}$, albeit only under dry conditions, as its capacity decreases by $32 \%$ in the presence of water. ${ }^{10}$ An additional strategy to increase the adsorption capacity toward $\mathrm{SO}_{x}$ and $\mathrm{NO}_{2}$ is the incorporation of metal oxides in silica supports. ${ }^{10}$ For example, the adsorption of $\mathrm{NO}_{2}$ via the silica support, SBA-15, increases from $0.3 \mathrm{mmol} \mathrm{g}^{-1}$ to $5.0 \mathrm{mmol} \mathrm{g}^{-1}$ when SBA-15-supported cerium-zirconium mixed oxides is employed instead. ${ }^{10}$

Several studies have investigated clays for the adsorption of VOCs. For instance, the performance of mesoporous pillared laponite for the removal of VOCs was at least as good as that of zeolites, even though the performance of the zeolites depends on the partial pressure. ${ }^{120}$ For the adsorption of dioxins, bentonites perform better than zeolites, but worse than aluminas, while laponites perform poorly. ${ }^{133}$

\section{Nuclear Waste Containment}

Encapsulation of nuclear waste materials is a very complex issue, since a large variety of waste stream environmental factors will influence its effectiveness. For example, nuclear waste streams often exhibit extreme (low or high) pH values, and contain a broad range of radionuclide and/or benign salt concentrations. ${ }^{18,19,34-37,137}$ The composition of nuclear waste also varies according to the purpose (e.g. commercial or defense) and type (e.g. reactor) of nuclear source. ${ }^{18-20,34,138,139}$ Different approaches to encapsulate are used for distinct objectives in process control, e.g. the removal of contaminants, or the disposal of waste streams. In addition, both short- and long-term environmental effects of encapsulation must be taken into consideration, as some radionuclides such as ${ }^{137} \mathrm{Cs}$, and ${ }^{90} \mathrm{Sr}$ are short-lived, but generate considerable heat, while others exhibit a longer half-life, and give off less heat. ${ }^{11,19,37,42,139-141}$ This means that different radionuclides must either be separated, or the container material for the waste must be able to endure both types of radionuclides. The ideal encapsulation material should be chemically and thermally durable, resistant to radiation and leaching, and accommodate high adsorbate loadings. ${ }^{19,34,35,40,43,44,142}$ Adsorption capacities and waste loadings for various options for nuclear waste encapsulation can be found in Table 5. 
Table 5. Reported inorganic adsorbents used to encapsulate various types of nuclear waste (adsorbates) together with their adsorption capacity performance metrics.

\begin{tabular}{|c|c|c|c|}
\hline Adsorbent & Adsorbate & Maximum Reported Capacity & Ref. \\
\hline Natural zeolite & ${ }^{110} \mathrm{Ag}$ & ca. 1.4 meq g$^{-1}$ & 143 \\
\hline Hydrous bismuth oxide & $\mathrm{Ba}^{2+}$ & $0.958 \times 10^{-3} \mathrm{mmol} \mathrm{g}^{-1}$ & 144 \\
\hline Hydrous ferric oxide & $\mathrm{Ba}^{2+}$ & $0.617 \times 10^{-3} \mathrm{mmol} \mathrm{g}^{-1}$ & 145 \\
\hline Trititanate nanofibers & $\mathrm{Ba}^{2+}$ & $2.33 \mathrm{meq} \mathrm{g}^{-1}$ & 146 \\
\hline Trititanate- $\mathrm{H}$ nanofibers $\left(\mathrm{Na}_{1.5} \mathrm{H}_{0.5} \mathrm{Ti}_{3} \mathrm{O}_{7}\right)$ & $\mathrm{Ba}^{2+}$ & 1.90 meq g $^{-1}$ & 146 \\
\hline Magnetite & $\mathrm{Co}^{2+}$ & $3.89 \mu \mathrm{mol} \mathrm{m}{ }^{-2}$ & 147 \\
\hline Magnetite-silica composite & $\mathrm{Co}^{2+}$ & $7.54 \mu \mathrm{mol} \mathrm{m}{ }^{-2}$ & 147 \\
\hline Clinoptilolite & $\mathrm{Co}^{2+}$ & $3.40 \mathrm{mg} \mathrm{g}^{-1}$ & 148 \\
\hline Natural zeolite & ${ }^{60} \mathrm{Co}$ & ca. 1.1 meq g $^{-1}$ & 143 \\
\hline MF5-1 & $\mathrm{Cr}^{6+}$ & $7.2 \mathrm{mg} \mathrm{g}^{-1}$ & 149 \\
\hline MF5-2 & $\mathrm{Cr}^{6+}$ & $10 \mathrm{mg} \mathrm{g}^{-1}$ & 149 \\
\hline Mesoporous silica & $\mathrm{Cs}^{+}$ & $27.40 \mathrm{mg} \mathrm{g}^{-1}$ & 141 \\
\hline $\begin{array}{l}\text { dibenzo-18-crown-6 ether immobilized mesoporous } \\
\text { silica }\end{array}$ & $\mathrm{Cs}^{+}$ & $50.23 \mathrm{mg} \mathrm{g}^{-1}$ & 141 \\
\hline Zeolite from Chihuahua Mexico & $\mathrm{Cs}^{+}$ & $46.77 \mathrm{mg} \mathrm{g}^{-1}$ & 150 \\
\hline Zeolite from Oaxaca Mexico & $\mathrm{Cs}^{+}$ & $64.56 \mathrm{mg} \mathrm{g}^{-1}$ & 150 \\
\hline Alkali-activated slag cement & $\mathrm{Cs}^{+}$ & $6.9 \mathrm{mg} \mathrm{g}^{-1}$ & 151 \\
\hline Zeolite 13X & $\mathrm{Cs}^{+}$ & 1.87 meq g $^{-1}$ & 152 \\
\hline Zeolite F & $\mathrm{Cs}^{+}$ & 3.02 meq g $^{-1}$ & 152 \\
\hline Zeolite $\mathrm{P}<\mathrm{sub}>\mathrm{C}$ & $\mathrm{Cs}^{+}$ & 1.51 meq g $^{-1}$ & 152 \\
\hline Mordenite & $\mathrm{Cs}^{+}$ & 0.90 meq g $^{-1}$ & 152 \\
\hline Chabazite & $\mathrm{Cs}^{+}$ & 2.18 meq g $^{-1}$ & 152 \\
\hline Magnetite & $\mathrm{Cs}^{+}$ & $0.703 \mu \mathrm{mol} \mathrm{m}{ }^{-2}$ & 147 \\
\hline Magnetite-silica composite & $\mathrm{Cs}^{+}$ & $1.922 \mu \mathrm{mol} \mathrm{m}{ }^{-2}$ & 147 \\
\hline $\mathrm{Na}_{0.2} \mathrm{Mo}_{0.03} \mathrm{~W}_{0.97} \mathrm{O}_{3} * \mathrm{ZH}_{2} \mathrm{O}$ - polyacrylonitrile composite & $\mathrm{Cs}^{+}$ & $8.91 \mathrm{mg} \mathrm{g}^{-1}$ & 153 \\
\hline Ferrierite & $\mathrm{Cs}^{+}$ & $0.84 \mathrm{mmol} \mathrm{g}^{-1}$ & 154 \\
\hline Clinoptilolite & $\mathrm{Cs}^{+}$ & $45.12 \mathrm{mg} \mathrm{g}^{-1}$ & 148 \\
\hline Na-natural clinoptilolite & ${ }^{134} \mathrm{Cs}^{+}$ & $1.27 \mathrm{mmol} \mathrm{g}^{-1}$ & 155 \\
\hline Na-natural chabazite & ${ }^{134} \mathrm{Cs}^{+}$ & $2.07 \mathrm{mmol} \mathrm{g}^{-1}$ & 155 \\
\hline Na-natural mordenite & ${ }^{134} \mathrm{Cs}^{+}$ & $1.93 \mathrm{mmol} \mathrm{g}^{-1}$ & 155 \\
\hline Na-synthetic mordenite & ${ }^{134} \mathrm{Cs}^{+}$ & $1.67 \mathrm{mmol} \mathrm{g}^{-1}$ & 155 \\
\hline Chabazite & ${ }^{137} \mathrm{Cs}^{+}$ & $2.56 \mathrm{mmol} \mathrm{g}^{-1}$ & 156 \\
\hline MS-13X & ${ }^{137} \mathrm{Cs}^{+}$ & $2.60 \mathrm{mmol} \mathrm{g}^{-1}$ & 156 \\
\hline $\begin{array}{l}\text { Ammonium molybdophosphate-hollow aluminosilicate } \\
\text { microsphere composite }\end{array}$ & ${ }^{137} \mathrm{Cs}^{+}$ & $21.9 \mathrm{mg} \mathrm{g}^{-1}$ & 157 \\
\hline IONSIV IE-911 (granulated TAM-5) & ${ }^{137} \mathrm{Cs}^{+}$ & $69 \mathrm{mg} \mathrm{g}^{-1}$ & 158 \\
\hline TAM-5 (crystalline silicotitanate) & ${ }^{137} \mathrm{Cs}^{+}$ & $82 \mathrm{mg} \mathrm{g}^{-1}$ & 158 \\
\hline Natural zeolite & ${ }^{137} \mathrm{Cs}^{+}$ & ca. 1.9 meq g $^{-1}$ & 143 \\
\hline Zeolite 13X & $\mathrm{Eu}^{3+}$ & $1.41 \mathrm{meq} \mathrm{g}^{-1}$ & 152 \\
\hline Zeolite F & $\mathrm{Eu}^{3+}$ & 0.76 meq g $^{-1}$ & 152 \\
\hline Zeolite $\mathrm{P}_{\mathrm{c}}$ & $\mathrm{Eu}^{3+}$ & 0.10 meq g $^{-1}$ & 152 \\
\hline Mordenite & $\mathrm{Eu}^{3+}$ & 0.18 meq g $^{-1}$ & 152 \\
\hline Chabazite & $\mathrm{Eu}^{3+}$ & 0.39 meq g $^{-1}$ & 152 \\
\hline Iron phosphate glass & $\begin{array}{l}\text { Simulated HLW } \\
\text { mimicing tank farm B } \\
\text { at Hanford, WA }\end{array}$ & 40 wt $\%$ & 159 \\
\hline Lead-iron phosphate glass & $\begin{array}{l}\text { Simulated nuclear } \\
\text { waste }\end{array}$ & ca. $15-20$ wt\% & 160 \\
\hline Iron phosphate glass & Spent nuclearfuel & 15 wt\% & 161 \\
\hline Hydrous ferric oxide & $\mathrm{Sr}^{2+}$ & $0.662 \times 10^{-3} \mathrm{mmol} \mathrm{g}^{-1}$ & 145 \\
\hline Zeolite 13X & $\mathrm{Sr}^{2+}$ & 3.8 meq g $^{-1}$ & 152 \\
\hline Zeolite F & $\mathrm{Sr}^{2+}$ & $2.65 \mathrm{meq} \mathrm{g}^{-1}$ & 152 \\
\hline Zeolite $\mathrm{P}_{\mathrm{c}}$ & $\mathrm{Sr}^{2+}$ & $1.65 \mathrm{meq} \mathrm{g}^{-1}$ & 152 \\
\hline Mordenite & $\mathrm{Sr}^{2+}$ & $0.37 \mathrm{meq} \mathrm{g}^{-1}$ & 152 \\
\hline
\end{tabular}




\begin{tabular}{|c|c|c|c|}
\hline Chabazite & $\mathrm{Sr}^{2+}$ & 1.8 meq g- $^{-1}$ & 152 \\
\hline Potassium titanosilicate & $\mathrm{Sr}^{2+}$ & 0.3 meq g- $^{-1}$ & 162 \\
\hline Magnetite & $\mathrm{Sr}^{2+}$ & $3.92 \mu \mathrm{mol} \mathrm{m}{ }^{2}$ & 147 \\
\hline Magnetite-silica composite & $\mathrm{Sr}^{2+}$ & $9.73 \mu \mathrm{mol} \mathrm{m}{ }^{2}$ & 147 \\
\hline $\mathrm{Na}_{0.2} \mathrm{Mo}_{0.03} \mathrm{~W}_{0.97} \mathrm{O}_{3} * \mathrm{ZH}_{2} \mathrm{O}$ - polyacrylonitrile composite & $\mathrm{Sr}^{2+}$ & $1.66 \mathrm{mg} \mathrm{g}^{-1}$ & 153 \\
\hline Layered $\mathrm{K}_{2 x} \mathrm{Mn}_{x} \mathrm{Sn}_{3-\mathrm{x}} \mathrm{S}_{6}(\mathrm{x}=0.95)$ & $\mathrm{Sr}^{2+}$ & $77 \mathrm{mg} \mathrm{g}^{-1}\left(0.9 \mathrm{mmol} \mathrm{g}^{-1}\right)$ & 163 \\
\hline Zeolite A & $\mathrm{Sr}^{2+}$ & $0.33 \mathrm{mmol} \mathrm{g}^{-1}$ & 154 \\
\hline Clinoptilolite & $\mathrm{Sr}^{2+}$ & $11.64 \mathrm{mg} \mathrm{g}^{-1}$ & 148 \\
\hline Trititanate nanofibers & $\mathrm{Sr}^{2+}$ & $1.26 \mathrm{meq} \mathrm{g}^{-1}$ & 146 \\
\hline Trititanate- $\mathrm{H}$ nanofibers $\left(\mathrm{Na}_{1.5} \mathrm{H}_{0.5} \mathrm{Ti}_{3} \mathrm{O}_{7}\right)$ & $\mathrm{Sr}^{2+}$ & $1.14 \mathrm{meq} \mathrm{g}^{-1}$ & 146 \\
\hline Chabazite & ${ }^{85} \mathrm{Sr}^{2+}$ & $0.93 \mathrm{mmol} \mathrm{g}^{-1}$ & 156 \\
\hline MS-13X & ${ }^{85} \mathrm{Sr}^{2+}$ & $2.33 \mathrm{mmol} \mathrm{g}^{-1}$ & 156 \\
\hline Natural zeolite & ${ }^{90} \mathrm{Sr}^{2+}$ & ca. 2.2 meq g $^{-1}$ & 143 \\
\hline Zeolite-bearing volcaniclastic rock & $\mathrm{Th}^{4+}$ & $12.41 \mathrm{mg} \mathrm{g}^{-1}$ & 164 \\
\hline Expanded perlite & $\mathrm{Th}^{4+}$ & $84 w t \%$ & 165 \\
\hline MAA-g-CTS/B & $\mathrm{Th}^{4+}$ & $97.81 \mathrm{mg} \mathrm{g}^{-1}$ & 140 \\
\hline Clinoptilolite-polyacrylonitrile composite & $\mathrm{Th}^{4+}$ & $0.04 \mathrm{mmol} \mathrm{g}^{-1}$ & 166 \\
\hline Al-pillared rectorite & $\mathrm{Th}^{4+}$ & $0.14 \mathrm{mmol} \mathrm{g}^{-1}$ & 167 \\
\hline MX-80 bentonite & $\mathrm{Th}^{4+}$ & $0.275 \mathrm{mmol} \mathrm{g}^{-1}$ & 168 \\
\hline Natural clinoptilolite & $\mathrm{Th}^{4+}$ & 0.25 meq g $^{-1}$ & 169 \\
\hline Natural mordenite & $\mathrm{Th}^{4+}$ & 0.64 meq g-1 $^{-1}$ & 169 \\
\hline $\mathrm{NaA}$ & $\mathrm{Th}^{4+}$ & $0.85 \mathrm{meq} \mathrm{g}^{-1}$ & 169 \\
\hline $\mathrm{NaX}$ & $\mathrm{Th}^{4+}$ & $1.20 \mathrm{meq} \mathrm{g}^{-1}$ & 169 \\
\hline Natural clinoptilolite & Uranium ions & $2.88 \mathrm{mg} \mathrm{g}^{-1}$ & 170 \\
\hline Lead monoxide & Uranium ions & $13.8 \mathrm{mg} \mathrm{g}^{-1}$ & 92 \\
\hline Beryllium oxide & Uranium ions & $17.6 \mathrm{mg} \mathrm{g}^{-1}$ & 92 \\
\hline Aluminium hydroxide & Uranium ions & $18.1 \mathrm{mg} \mathrm{g}^{-1}$ & 92 \\
\hline Barium sulfate & Uranium ions & $20.5 \mathrm{mg} \mathrm{g}^{-1}$ & 92 \\
\hline Manganese dioxide & Uranium ions & $20.7 \mathrm{mg} \mathrm{g}^{-1}$ & 92 \\
\hline Zinc oxide & Uranium ions & $29.9 \mathrm{mg} \mathrm{g}^{-1}$ & 92 \\
\hline Ferric hydroxide & Uranium ions & $34.6 \mathrm{mg} \mathrm{g}^{-1}$ & 92 \\
\hline Magnesium oxide & Uranium ions & $45.0 \mathrm{mg} \mathrm{g}^{-1}$ & 92 \\
\hline $\begin{array}{l}\text { 1:3:4 composite ratio of aluminum hydroxide, ferric } \\
\text { hydroxide, activated carbon }\end{array}$ & Uranium ions & $112 \mathrm{mg} \mathrm{g}^{-1}$ & 92 \\
\hline Zeolite-bearing volcaniclastic rock & Uranium ions & $8.70 \mathrm{mg} \mathrm{g}^{-1}$ & 164 \\
\hline Manganese oxide coated zeolite & $U_{6+}^{6+}$ & $15.1 \mathrm{mg} \mathrm{g}^{-1}$ & 171 \\
\hline Natural zeolitic tuff & $U^{6+}$ & $92 \%$ removal & 172 \\
\hline
\end{tabular}

4.1 Adsorption. The removal of radionuclides from leakages often benefit from adsorption-based encapsulation, as the pollutants are usually present in trace amounts. Moreover, adsorption processes have been successfully used for the filtration of waste streams in order to remove radionuclides.

Zeolites exhibit particularly high selectivity for $\mathrm{Cs}^{+}$ions, though their selectivity toward $\mathrm{Sr}^{2+}$, $\mathrm{Th}^{4+}$, and uranium ions can reach acceptable levels under the right conditions. Many reports show that the adsorption capacity of individual zeolites depends on diverse factors such as $\mathrm{pH}$ value, concentration, temperature, and the presence of benign salts. The uptake capacity can be improved by including zeolites in composite materials. ${ }^{166,171,173}$ For example, El-Kamash et al. (2006) ${ }^{173}$ reported that loading Portland cement with radionuclide-containing zeolite $\mathrm{A}$ increased the compressive strength of the adsorbent and reduced leaching rates compared to results that use the cement alone. Han et al. (2007) ${ }^{171}$ demonstrated that the coating of natural zeolite by manganese oxides effectively removes $\mathrm{U}^{6+}$ ions from aqueous solutions, while the removal of Th4+ ions (which were used as a model for plutonium ions) was investigated by Kaygun and Akyil (2007), 166 using a polyacrylonitrile (PAN)-zeolite composite. Their results showed that the composite was both economical and effective for the removal of $\mathrm{Th}^{4+}$ ions and demonstrated excellent selectivity.

Titanates represent an interesting alternative for the adsorption of radionuclides. The most prominent titanate-based material is SYNROC, a titanate ceramic based on the naturally occurring minerals hollandite, perovskite, zirconolite, and rutile. ${ }^{19}$ 
Although requiring a more complex processing method than the industry standard borosilicate glass, SYNROC exhibits higher chemical, thermal, and mechanical stability, as well as a higher adsorption capacity for radionuclides, particularly for the actinides. Sodium titanosilicates have also garnered interest, since Möller et al. (2002) ${ }^{174}$ reported a sodium titanosilicate that presented high selectivity for ${ }^{134} \mathrm{Cs}^{+}$adsorption in acidic solutions, as well as high selectivity for ${ }^{85} \mathrm{Sr}^{2+}$ in neutral and alkaline solutions. Moreover, their results showed improvements in selectivity over inactive salts with lower crystallinity, even though this may lead to lower chemical and physical resistance. Other sodium titanates, such as the hydrous crystalline sodium silicotitanate, TAM-5, or its granulated form, IONSIV IE-911, were able to effectively remove $\mathrm{Cs}^{+}$and $\mathrm{Sr}^{2+}$ ions from acidic nuclear waste streams, while manifesting reasonably fast kinetics, good exchange capacity $\left(\leq 82 \mathrm{mg} \mathrm{g}^{-1}\right)$, and high selectivity, although high concentrations of $\mathrm{Na}^{+}$ions in the adsorbate solution can decrease the selectivity for $\mathrm{Cs}^{+}$ion adsorbates. ${ }^{138,158}$ The sodium titanate, SrTreat, exhibits optimal selectivity toward $\mathrm{Sr}^{2+}$ ions in alkaline streams, whereby the selectivity remained virtually unaffected by the concomitant presence of high concentrations of sodium, potassium, lithium, magnesium, or ammonium cations. Interestingly, a decreased effectiveness in strontium adsorption was observed for SrTreat in the presence of $\mathrm{Ca}^{2+}$ ions. ${ }^{175} \mathrm{~A}$ sodium nonatitanate displays a $\mathrm{Sr}^{2+}$ ion selectivity enhancement with decreasing nonatitanate crystallinity, as well as high stability in basic media, with good radiation and thermal stability. These results suggest that such materials could be useful for certain types of nuclear waste generated from defense purposes, while they seem less appropriate for the treatment of contaminated groundwater. ${ }^{162} \mathrm{~A}$ potassium titanosilicate was found to present good results for the removal of ${ }^{89} \mathrm{Sr}^{2+}$ ions from simulated waste streams, as well as for the removal of ${ }^{137} \mathrm{Cs}^{+}$ions from groundwater. ${ }^{162}$ Yang et al. (2008) ${ }^{146}$ determined that trititanate nanofibers were suitable for the isolation of $\mathrm{M}^{2+}$ radioactive ions $\left(\mathrm{M}^{2+}=\mathrm{Sr}^{2+}, \mathrm{Ba}^{2+}\right)$ from contaminated water, owing to their good selectivity for these ions, their ability to permanently trap, and the potential for the fibres to be readily disbursed without the problem of aggregation of the fibres, which is often found with clays and zeolites. These nanofibers further present quick adsorption characteristics compared to other adsorbents, and can be easily filtered out.

The high durability of minerals has prompted investigations into their potential use in natural or synthetic form; for example, apatite, monazite, bentonite, perovskite, zirconates, perlite, and magnetite-based materials have all encapsulated radionuclides. Monazite, a mixed lanthanide orthophosphate, shows a particularly interesting ability to accommodate actinides. Its chemical durability is higher than that of borosilicate glass, and increases with increasing temperature, while its waste loadings typically reach $20 \mathrm{wt} \% .{ }^{40}$ Monazite is also expected to be radiation resistant, and to accommodate significant amounts of Th4+ and uranium ions, owing to naturally high contents of uranium and thorium within the mineral, which subjects monazite to significant alpha decay damage on geological time scales. Despite this radiation damage, the mineral is typically found in its crystalline form, which suggests high resistance. ${ }^{36}$ Indeed, most nuclear waste adsorbent investigations focusing on minerals are concerned with the uptake of $\mathrm{Th}^{4+}$ ions. A literature-based study of geological considerations for actinide-containing waste forms by Ewing et al. (1999) 34 suggested that zircon, monazite, and polymorphs of zirconia exhibit chemical and mechanical durability parameters, that are sufficiently attractive to render these materials with suitable prospects for the long-term storage of radionuclides. An organic bentonite composite containing poly(methacrylic acid)-graphed chitosan demonstrates an excellent adsorption capacity for Th ${ }^{4+}$ ions, particularly at higher Th${ }^{4+}$ ion concentrations ( $\leq 94.51 \mathrm{mg} \mathrm{g}^{-1}$ at a concentration of $250 \mathrm{mg} \mathrm{L}^{-1}$ ), as well as stable adsorption/desorption behavior. ${ }^{140}$ Magnetite and magnetite-silica composites show a pH-dependent adsorption capacity with a selectivity for $\mathrm{Co}^{2+}$ ions over $\mathrm{Sr}^{2+}$ and $\mathrm{Cs}^{+}$ions. ${ }^{147}$ However, these minerals did not perform as well as other materials, even though regeneration was favorable, especially under acidic conditions $(\mathrm{pH}=1-3)$. Dyer et al. $(2000)^{176} \mathrm{found}$ that synthetic cryptomelane-type manganese oxides exhibit a high affinity for $\mathrm{K}^{+}$and ${ }^{110} \mathrm{Ag}^{+}$ions, while todorokite-type tunnel manganese oxides effectively remove ${ }^{57} \mathrm{Co}^{2+},{ }^{137} \mathrm{Cs}^{+}$, and ${ }^{89} \mathrm{Sr}^{2+}$ ions.

Tungstates represent another type of material that has been investigated for nuclear waste processing, especially tungstate bronze phases. A series of papers on tungstate-bronze-based ceramics explored: their ability to simultaneously trap $\mathrm{Cs}^{+}, \mathrm{Sr}^{2+}$, and lanthanide ions; their performance as composite materials; and alternative fabrication methods. ${ }^{177-179}$ These studies found that tungstate-bronze-based materials effectively immobilize $\mathrm{Cs}^{+}$ions, that they exhibit decreased durability with respect to $\mathrm{Sr}^{2+}$ ions in acidic conditions, may achieve simultaneous trapping of lanthanides with unaffected leaching characteristics, and show a high tolerance for the inclusion of other oxides. ${ }^{177,179}$ Composites, consisting of molybdenum-doped hexagonal tungstate bronze (MoW-HTB) and polyacrylonitrile (PAN), display excellent leach resistance, which matched or surpassed those of saturated powder phases and a titanate reference material. ${ }^{178}$ Another study on granulated MoW-HTB/PAN composites specifically targeted the removal of $\mathrm{Cs}^{+}$and $\mathrm{Sr}^{2+}$ ions from acidic waste streams. ${ }^{153}$ The composite was able to separate $\mathrm{Cs}^{+}$and $\mathrm{Sr}^{2+}$ ions, whereby the $\mathrm{Sr}^{2+}$ ion-exchange capacity was highly dependent on the concentration of $\mathrm{Cs}^{+}$ions. 
A plethora of other materials has also been explored. For example, alkali-activated slag cement (AASC) been found to show high thermal and chemical resistance, low porosity, a better immobilization of $\mathrm{Cs}^{+}$ions and lower leach rates relative to ordinary Portland and high-aluminate cement. ${ }^{180}$ Furthermore, when such AASCs contain zeolite and silica fume, high waste loadings ( $\leq 25$ wt\%) have been predicted by simulation, whereby the resulting composites retain high compressive strength, low porosity, and low leaching levels of $\mathrm{Cs}^{+}$and $\mathrm{Sr}^{2+}$ ions. ${ }^{151}$ Even though the adsorption rates for these composites are lower than those of zeolites, potential applications may be encountered in the context of solidifying low- and intermediate-level waste. Other cement-based adsorbents, such as concrete formed under elevated temperature and pressure (FUETAP) that uses the heat of the waste to accelerate the curing of the cement, show leaching rates and adsorption loadings ( $\leq 15-25$ wt $\%$ ) comparable to borosilicate glass. ${ }^{40}$ Magnesium oxychloride cements are effective for the removal of $\mathrm{Cr}^{4+}$ ions, whereby some samples are able to selectively remove $\mathrm{Cr}^{4+}$ ions in the presence of $\mathrm{Cr}^{3+}$ ions. ${ }^{149}$

Various oxides have also been studied for nuclear waste encapsulation, including alkaline earth oxides, ${ }^{92}$ hydrous bismuth oxides, ${ }^{144}$ and hydrous ferric oxides. ${ }^{145}$ Among the alkaline earth oxidesinvestigated by Dai and Wu (1975), ${ }^{92}$ magnesium, iron-, and zinc-based oxides exhibit high adsorption capacities for uranium ions, and a significantly increased capacity at room temperature was observed for a 1:3:4 composite of aluminum hydroxide, ferric hydroxide, and activated carbon. In materials based on hydrous bismuth and hydrous ferric oxides, higher temperatures, higher pH values, and higher concentrations favored the adsorption of $\mathrm{Ba}^{2+}$ and/or $\mathrm{Sr}^{2+}$ ions, even though their uptake was not fully reversible in either material. For the hydrous ferric oxide, irradiation or the presence of other ions within the solution suppressed the uptake capacity of $\mathrm{Ba}^{2+}$ and/or $\mathrm{Sr}^{2+}$ ions. ${ }^{144,145}$ Studies on hexacyanoferrates showed a two- to fivefold higher selectivity toward $\mathrm{Cs}^{+}$ions for nonstoichiometric potassium nickel hexacyanoferrate(II) relative to that of zeolites. ${ }^{181}$ Potassium cobalt hexacyanoferrate(II) and potassium copper cobalt hexacyanoferrate(II) were found to effectively adsorb $\mathrm{Cs}^{+}$ions from neutral and highly alkaline solutions, whereby the rate of adsorption in the latter was lower than that in the former. Silver-based adsorbents may offer a potential solution for the encapsulation of radioactive iodine, particularly silver silica and silver alumina. ${ }^{182}$ Since silver silica was discovered to exhibit a decrease in removal efficiency at lower temperatures $(T \approx 303 \mathrm{~K})$, silver alumina was developed, which showed good removal efficiency as well as long-term stability. Layered metal sulfides (KMS-1) have demonstrated a high selectivity for $\mathrm{Sr}^{2+}$ and $\mathrm{Sr}(\mathrm{OH})^{+}$ ions in acidic and basic solutions, even in the presence of other hard cations, such as $\mathrm{Na}^{+}$or $\mathrm{H}^{+} .163$ Observed adsorption capacities were comparable to those of the then best $\mathrm{Sr}^{2+}$ adsorbents, and KMS-1 even outperformed several commercial materials when in acidic solution (maximum capacity: $77 \mathrm{mg} \mathrm{g}^{-1}$ ). Awual et al. (2014)141 developed a conjugate of mesoporous silica with a macrocyclic organic ligand and tested it for its ability to remove ${ }^{197} \mathrm{Cs}^{+}$ions. The adsorption capacity of this conjugate was encouraging, even in the presence of high concentrations of $\mathrm{K}^{+}$and $\mathrm{Na}^{+}$cations in the adsorbate solution, although results were highly sensitive to $\mathrm{pH}$ conditions. However, the adsorbent displayed good recycling behavior.

4.2 Vitrification. Borosilicates have long been the industry standard for vitrification, i.e. the transformation from a substance to a non-crystalline amorphous solid (glass). Borosilicates are able to dissolve 10-30 wt\% of a wide variety of waste types, their properties can be easily optimized, they exhibit attractive chemical and mechanical durability, as well as good radiation resistance. ${ }^{19,40}$ The principal drawback of borosilicates is their inefficiency for the removal of actinides. Investigations are accordingly focused on the circumvention of this shortcoming, or on the replacement of borosilicates. For the removal of plutonium ions from highly radioactive waste, lanthanide borosilicate glasses containing either $\mathrm{Gd}^{3+}$ and $\mathrm{Zr}^{4+}$, or $\mathrm{Gd}^{3+}$ and $\mathrm{Hf}^{4+}$ ions have been examined. ${ }^{183}$ The results showed that $\mathrm{Gd}^{3+} / \mathrm{Hf}^{4+}$ glasses are very durable, and that leaching could be minimized if these glasses are stored in Teflon containers.

The focus for alternatives to borosilicate glasses revolves around phosphate glasses. In general, phosphates display lower thermal stability and chemical durability than borosilicates, but a high solubility for sulfates. ${ }^{19,36,137} \mathrm{~A}$ positive exception is iron-containing phosphate glass, which often performs at least as well as borosilicate glass. ${ }^{19,159-161}$ Vitrifying highly radioactive waste with $\mathrm{P}_{2} \mathrm{O}_{3}$ and $\mathrm{Fe}_{2} \mathrm{O}_{3}$ can result in a comparably chemically durable glass. Moreover, only minimal additional materials need to be added to the waste material to create iron phosphate glasses, and waste does not need to be chemically treated prior to vitrification in order to reduce its phosphate content, in contrast to the analogous process for borosilicate glasses. ${ }^{159} \mathrm{Accordingly}$, the final waste-containing materials are smaller in volume than theirborosilicate analogs, which reduces costs. Iron-phosphate glasses that also contain lead within the framework exhibit even better adsorbent characteristics: such glasses are not as corrosive as other phosphate glasses, they display better solubility for actinide oxides which is promising for the immobilization of weaponderived plutonium ions, and leach rates that are 10-1000 times lower than those of borosilicate glass. ${ }^{19,160}$ However, 
crystallization remains problematic for phosphate adsorbents, as even low degrees of crystallinity may decrease the durability of the glass substantially.

The direct vitrification of spent nuclear fuel such as $\mathrm{UO}_{2}$ pellets has also been examined, as it presents an easy means of processing. Standard fuel is comprised of $\mathrm{UO}_{2}$ pellets, stacks of which are encased in Zircaloy-2 or -4 . When the fuel is spent, solid solutions are formed containing residual $\mathrm{UO}_{2}$, along with actinides, lanthanides, and some fission products. ${ }^{40}$ Originally, the idea of spent nuclear fuel as a wasteform involved direct disposal of the spent nuclear fuel in a repository. Yet, the durability of spent fuel forms is highly dependent upon the irradiation history and the oxidation potential of the waste ions. For example, some types of nuclear waste can be insoluble under reducing conditions, while corrosion may occur under oxidizing conditions. ${ }^{40}$ Furthermore, high leaching rates may occur upon exposure to water, volatile species may accumulate within the spent nuclear fuel, while cracking and the formation of voids in the spent nuclear fuel is common. A proposed alternative is to vitrify spend nuclear fuel within iron-phosphate glasses with waste loadings of $\leq 15$ wt\% which may result in less leaching relative to borosilicate glass. ${ }^{161}$ An additional benefit to the vitrification of spent nuclear fuel within iron-phosphate glass is that the aluminum casings of the spent nuclear fuel do not have to be removed, as the inclusion of $\mathrm{Al}_{2} \mathrm{O}_{3}$ further improves durability of the glass, provided that $\sim 2.5 \mathrm{wt} \% \mathrm{Na}_{2} \mathrm{O}$ is added.

4.3 Multi-phase encapsulation. Glass-ceramics combine the higher chemical durability and adsorption capacity of ceramics with the easy processability and structural flexibility of glasses. The encapsulation of radionuclides with long half-lives is accomplished within the crystalline phase, while the fission products, such as $\mathrm{Cs}^{+}$ions, reside in the glass. In this context, adsorbents with the most interesting prospects are zirconolite-bearing glass-ceramics, ${ }^{184-188}$ which are expected to exhibit good long-term stability. A principal drawback of such zirconolites should be the possibility for actinides to reside in the glass adsorbent, which would afford their leaching into the surrounding environment. Accordingly, investigations into pyrochlore-based glass-ceramics are currently in progress, which may render these materials also suitable for actinide-rich waste. ${ }^{186}$ For several other glass-ceramics, such as calcium titanium silicates and calcium magnesium silicates, high loadings (25-30 wt\%) have been reported, whereas documented loadings for alkali titanium silicates are even higher ( $\leq 75 \mathrm{wt} \%) .{ }^{19}$ Calcium titanium silicates, based on $\mathrm{CaUTi}_{2} \mathrm{O}_{7}$ and $\mathrm{UTi}_{2} \mathrm{O}_{6} \mathrm{With}$ crystalline phases, are very leach resistant and may yield high loadings of $\mathrm{UO}_{2}(\leq 50 \mathrm{wt} \%) .{ }^{19}$ Aluminosilicate glasses containing discrete titanite crystals promise high durability, low processing temperatures, low leaching rates, accommodation of a wide range of waste materials, and increased chemical durability for some waste types. ${ }^{40}$ Studies on a series of composites containing caesium-loaded hexagonal tungstate bronzes, in combination with other oxides, showed that compositions low in silica and high in tungsten afford high caesium volatilization losses and poor durability, while higher proportions of silica furnish better durability. ${ }^{11}$ Furthermore, $\mathrm{WO}_{3}$ was found to have a typically beneficial influence on leaching relative to tungsten-free forms. However, individual performance of these tungsten-based glass-ceramics depends on the crystalline phases in which the caesium is contained. Sodalite phases show poor leaching rates, while bronzoid and pollucite phases perform better. ${ }^{11}$

A different strategy for combining phases is the multi-barrierform, which accomplishes glass or ceramic encapsulation within a more durable phase, or by coating the glass or ceramic with another phase, creating a series of glass or ceramic barriers. Such coatings were found to enhance chemical durability, mechanical strength, and thermal stability. ${ }^{40}$

\section{Separation or Containment of Alternative Fuels}

While the encapsulation of waste materials is important for environmental preservation, so too is the encapsulation of alternative fuels that may prevent the production and accumulation of the aforementioned wastes in the first place. Climate change and other environmental concerns are the main driving forces behind the trend towards adopting more eco-friendly fuels. Methane and molecular hydrogen are among several prospective alternative fuel sources. Yet, irrespective of how these fuels will be employed commercially, some challenges regarding their purification and storage face their potential for innovation. Their adsorption into host frameworks offers a prospective solution to these issues by allowing for lower pressures and temperatures, as well as providing safe handling compared to other methods of storage which typically involve cryogenic systems for liquids or high-pressure tanks for compressed systems. ${ }^{12,30,189,190}$ 
5.1 Separation and purification of $\mathbf{C H}_{4} . \mathrm{CH}_{4}$ is an attractive alternative energy source for replacing the vehicular use of gasoline and diesel. Its employment would result in significant reductions in $\mathrm{CO}, \mathrm{CO}_{2}$, and $\mathrm{SO}_{2}$ emissions, the elimination of lead discharge, and lower costs compared to traditional fuels. ${ }^{108}$ Methane is the dominant constituent of natural gas which comprises $\sim 80-95 \% \mathrm{CH}_{4}$, along with minor contributions from $\mathrm{N}_{2}, \mathrm{CO}_{2}$, and various hydrocarbon-based compounds. Biogas also contains high proportions of $\mathrm{CH}_{4}$, but simultaneously possesses high amounts of $\mathrm{CO}_{2}$ and other trace compounds, which can vary depending on the fuel source. Biogas tends to be extracted from waste environments such as landfill sites and sewage plants; the $\mathrm{CH}_{4}$ contained within thus requires purification prior to use, in contrast to the case of natural gas. Adsorbents studied for $\mathrm{CH}_{4}$ separation and purification are listed in Table 6, along with reported adsorption capacities. Figure 5 shows molecular structures of select $\mathrm{CH}_{4}$ contaminants found in biogas and/or natural gas.

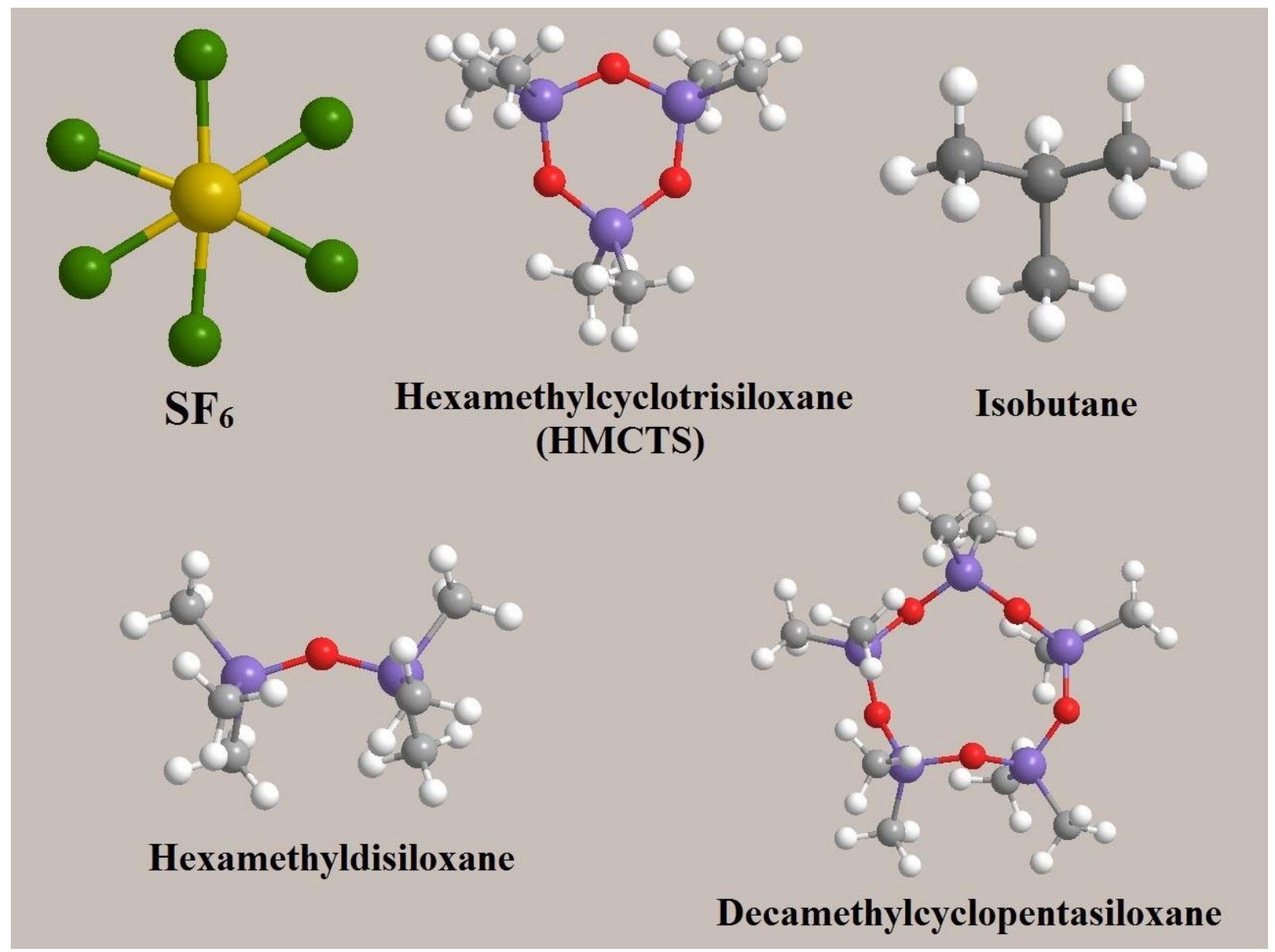

Figure 5. Examples of common contaminants found in $\mathrm{CH}_{4}$ sources: $\mathrm{SF}$, hexamethylcyclotrisiloxane (HMCTS), isobutane, hexamethyldisiloxane, and decamethylcyclopentasiloxane. (Atom colours: grey-C, white $-\mathrm{H}$, red-O, purple-Si, gold-S, green - F)

Table 6. Reported adsorption capacities for the encapsulation of $\mathrm{CH}_{4}$, and common contaminants found in biogas and natural gas, using inorganic adsorbents. * indicates where values either could not be obtained, or were not specified (eg. presented as a range); ${ }^{* *}$ indicates theoretical values

\begin{tabular}{llllll}
\hline Adsorbent & Adsorbate & $\begin{array}{l}\text { Maximum } \\
\text { Reported Capacity }\end{array}$ & Temperature & Pressure & Ref. \\
\hline Zeolite 13X & Argon & ca. $2.8 \mathrm{mmol} \mathrm{g}^{-1}$ & $190.65 \mathrm{~K}$ & $4640 \mathrm{kPa}$ & 191 \\
\hline
\end{tabular}




\begin{tabular}{|c|c|c|c|c|c|}
\hline Silicalite & $\mathrm{CF}_{4}$ & $\begin{array}{l}7.5 \text { molecules/unit } \\
\text { cell }\end{array}$ & $200 \mathrm{~K}$ & $100 \mathrm{kPa}$ & 192 \\
\hline Zeolite 13X & $\mathrm{CO}_{2}$ & 22.0 wt $\%$ & RT & $0.67 \mathrm{kPa}$ & 109 \\
\hline Zeolite 4A & $\mathrm{CO}_{2}$ & $5.1 w t \%$ & RT & $0.67 \mathrm{kPa}$ & 109 \\
\hline $\begin{array}{l}\text { Zr-pillared clay from } \\
\text { Benavila-Alentejo }\end{array}$ & $\mathrm{CO}_{2}$ & ca. $2.7 \mathrm{mmol} \mathrm{g}^{-1}$ & $215 \mathrm{~K}$ & $100 \mathrm{kPa}$ & 116 \\
\hline $\begin{array}{l}\text { Zr-pillared clay from Porto } \\
\text { Santo-Madeira }\end{array}$ & $\mathrm{CO}_{2}$ & ca. $2.6 \mathrm{mmol} \mathrm{g}^{-1}$ & $215 \mathrm{~K}$ & $100 \mathrm{kPa}$ & 116 \\
\hline Silicate & $\mathrm{CO}_{2}$ & $3.296 \mathrm{mmol} \mathrm{g}^{-1}$ & $276.8 \mathrm{~K}$ & $\begin{array}{l}2001.19 \\
\mathrm{kPa}\end{array}$ & 110 \\
\hline $\begin{array}{l}\text { Silicoaluminophosphate-34 } \\
\text { crystallized for } 24 \mathrm{~h}\end{array}$ & $\mathrm{CO}_{2}$ & $12.30 \mathrm{mmol} \mathrm{g}^{-1}$ & $278 \mathrm{~K}$ & $3000 \mathrm{kPa}$ & 193 \\
\hline $\begin{array}{l}\text { Silicoaluminophosphate-34 } \\
\text { crystallized for } 48 \mathrm{~h}\end{array}$ & $\mathrm{CO}_{2}$ & $18.18 \mathrm{mmol} \mathrm{g}^{-1}$ & $278 \mathrm{~K}$ & $3000 \mathrm{kPa}$ & 193 \\
\hline Sulfuric acid & $\begin{array}{l}\text { Decamethylcyclopentasiloxane } \\
\text { D5 }\end{array}$ & $>95 \%$ efficiency & $333 \mathrm{~K}$ & * & 194 \\
\hline Nitric acid & $\begin{array}{l}\text { Decamethylcyclopentasiloxane } \\
\text { D5 }\end{array}$ & $>95 \%$ efficiency & $333 \mathrm{~K}$ & $*$ & 194 \\
\hline Phosphoric acid & $\begin{array}{l}\text { Decamethylcyclopentasiloxane } \\
\text { D5 }\end{array}$ & $44-48 \%$ efficiency & $333 \mathrm{~K}$ & $*$ & 194 \\
\hline Silicate & Ethane & $2.598 \mathrm{mmol} \mathrm{g}^{-1}$ & $276.8 \mathrm{~K}$ & $\begin{array}{l}2108.69 \\
\mathrm{kPa}\end{array}$ & 110 \\
\hline Sulfuric acid & Hexamethyldisiloxane L2 & $>95 \%$ efficiency & $333 \mathrm{~K}$ & $*$ & 194 \\
\hline Nitric acid & Hexamethyldisiloxane L2 & $>95 \%$ efficiency & $333 \mathrm{~K}$ & $*$ & 194 \\
\hline Phosphoric acid & Hexamethyldisiloxane L2 & $53-60 \%$ efficiency & $333 \mathrm{~K}$ & $*$ & 194 \\
\hline Silicagel & HMCTS & $230 \mathrm{mg} \mathrm{g}^{-1}$ & RT & $101.3 \mathrm{kPa}$ & 195 \\
\hline Faujasite $\mathrm{NaX}$ & HMCTS & $276 \mathrm{mg} \mathrm{g}^{-1}$ & RT & $101.3 \mathrm{kPa}$ & 195 \\
\hline Silicate & Isobutane & $1.632 \mathrm{mmol} \mathrm{g}^{-1}$ & $276.8 \mathrm{~K}$ & $86.17 \mathrm{kPa}$ & 110 \\
\hline Mordenite & Methane & ca. $3.5 \mathrm{mmol} \mathrm{g}^{-1 * *}$ & $273 \mathrm{~K}$ & $10^{5} \mathrm{kPa}$ & 196 \\
\hline ZSM-5 (zeolite) & Methane & ca. $3.2 \mathrm{mmol} \mathrm{g}^{-1} * *$ & $273 \mathrm{~K}$ & $10^{5} \mathrm{kPa}$ & 196 \\
\hline Zeolite 13X & Methane & $5.719 \mathrm{mmol} \mathrm{g}^{-1}$ & $298 \mathrm{~K}$ & $4725 \mathrm{kPa}$ & 108 \\
\hline Silicalite & Methane & $\begin{array}{l}3.5 \text { molecules/unit } \\
\text { cell }\end{array}$ & $200 \mathrm{~K}$ & $100 \mathrm{kPa}$ & 192 \\
\hline MCM-41 & Methane & ca. $1.6 \mathrm{mmol} \mathrm{g}^{-1}$ & $303 \mathrm{~K}$ & $\begin{array}{l}\text { ca. } 1100 \\
\mathrm{kPa}\end{array}$ & 102 \\
\hline AlPO4-5 & Methane & ca. $0.40 \mathrm{mmol} \mathrm{g}^{-1}$ & $303 \mathrm{~K}$ & ca. $450 \mathrm{kPa}$ & 102 \\
\hline $\begin{array}{l}\text { Zr-pillared clay from } \\
\text { Benavila-Alentejo }\end{array}$ & Methane & ca. $0.85 \mathrm{mmol} \mathrm{g}^{-1}$ & $215 \mathrm{~K}$ & $100 \mathrm{kPa}$ & 116 \\
\hline $\begin{array}{l}\text { Zr-pillared clay from Porto } \\
\text { Santo-Madeira }\end{array}$ & Methane & ca. $0.70 \mathrm{mmol} \mathrm{g}^{-1}$ & $215 \mathrm{~K}$ & $100 \mathrm{kPa}$ & 116 \\
\hline Y-Zeolite & Methane & $0.475 \mathrm{mmol} \mathrm{g}^{-1}$ & $273 \mathrm{~K}$ & $100 \mathrm{kPa}$ & 197 \\
\hline Ag-exchanged Y-Zeolite & Methane & $0.351 \mathrm{mmol} \mathrm{g}^{-1}$ & $273 k$ & $100 \mathrm{kPa}$ & 197 \\
\hline Cu-exchanged Y-Zeolite & Methane & $0.617 \mathrm{mmol} \mathrm{g}^{-1}$ & $273 \mathrm{~K}$ & $100 \mathrm{kPa}$ & 197 \\
\hline Fe-exchanged Y-Zeolite & Methane & $0.796 \mathrm{mmol} \mathrm{g}^{-1}$ & $273 \mathrm{~K}$ & $100 \mathrm{kPa}$ & 197 \\
\hline $\begin{array}{l}\text { Y-Zeolite treated with } 1 \mathrm{M} \\
\mathrm{HCL}\end{array}$ & Methane & $0.597 \mathrm{mmol} \mathrm{g}^{-1}$ & $273 \mathrm{~K}$ & $100 \mathrm{kPa}$ & 197 \\
\hline $\begin{array}{l}\text { Y-Zeolite treated with } 3 \mathrm{M} \\
\mathrm{HCL}\end{array}$ & Methane & $0.450 \mathrm{mmol} \mathrm{g}^{-1}$ & $273 \mathrm{~K}$ & $100 \mathrm{kPa}$ & 197 \\
\hline $\begin{array}{l}\text { Y-Zeolite treated with } 5 \mathrm{M} \\
\mathrm{HCL}\end{array}$ & Methane & $0.154 \mathrm{mmol} \mathrm{g}^{-1}$ & $273 \mathrm{~K}$ & $100 \mathrm{kPa}$ & 197 \\
\hline Natural mordenite & Methane & $0.528 \mathrm{mmol} \mathrm{g}^{-1}$ & $273 \mathrm{~K}$ & $100 \mathrm{kPa}$ & 198 \\
\hline Ag-exchanged mordenite & Methane & $0.498 \mathrm{mmol} \mathrm{g}^{-1}$ & $273 \mathrm{~K}$ & $100 \mathrm{kPa}$ & 198 \\
\hline Cu-exchanged mordenite & Methane & $0.449 \mathrm{mmol} \mathrm{g}^{-1}$ & $273 \mathrm{~K}$ & $100 \mathrm{kPa}$ & 198 \\
\hline Fe-exchanged mordenite & Methane & $0.398 \mathrm{mmol} \mathrm{g}^{-1}$ & $273 \mathrm{~K}$ & $100 \mathrm{kPa}$ & 198 \\
\hline $\mathrm{HCl}$ treated mordenite & Methane & $0.384 \mathrm{mmol} \mathrm{g}^{-1}$ & $273 k$ & $100 \mathrm{kPa}$ & 198 \\
\hline Zeolite $13 \mathrm{X}$ & Methane & ca. $5.5 \mathrm{mmol} \mathrm{g}^{-1}$ & $258.15 \mathrm{~K}$ & $20000 \mathrm{kPa}$ & 191 \\
\hline Silicate & Methane & $2.661 \mathrm{mmol} \mathrm{g}^{-1}$ & $276.8 \mathrm{~K}$ & $101.85 \mathrm{kPa}$ & 110 \\
\hline
\end{tabular}




\begin{tabular}{|c|c|c|c|c|c|}
\hline $\begin{array}{l}\text { Silicoaluminophosphate-34 } \\
\text { crystallized for } 24 \mathrm{~h}\end{array}$ & Methane & $5.31 \mathrm{mmol} \mathrm{g}^{-1}$ & $278 \mathrm{~K}$ & $3000 \mathrm{kPa}$ & 193 \\
\hline $\begin{array}{l}\text { Silicoaluminophosphate-34 } \\
\text { crystallized for } 48 \mathrm{~h}\end{array}$ & Methane & $7.70 \mathrm{mmol} \mathrm{g}^{-1}$ & $278 \mathrm{~K}$ & $3000 \mathrm{kPa}$ & 193 \\
\hline Silicate & n-Butane & $1.732 \mathrm{mmol} \mathrm{g}^{-1}$ & $276.8 \mathrm{~K}$ & $101.85 \mathrm{kPa}$ & 110 \\
\hline Zeolite 13X & Nitrogen & ca. $2.7 \mathrm{mmol} \mathrm{g}^{-1}$ & $258.15 \mathrm{~K}$ & $\begin{array}{l}\text { ca. } 5000 \\
\mathrm{kPa}\end{array}$ & 191 \\
\hline Silicate & Propane & $2.266 \mathrm{mmol} \mathrm{g}^{-1}$ & $276.8 \mathrm{~K}$ & $537.51 \mathrm{kPa}$ & 110 \\
\hline Silicate & $\mathrm{SF}_{6}$ & $2.034 \mathrm{mmol} \mathrm{g}^{-1}$ & $276.8 \mathrm{~K}$ & $578.17 \mathrm{kPa}$ & 110 \\
\hline Alumina & Siloxane (HMCTS) & $310 \mathrm{mg} \mathrm{g}^{-1}$ & $673 \mathrm{~K}$ & $<0.133 \mathrm{kPa}$ & 199 \\
\hline Silica gel & Siloxane (HMCTS) & $760 \mathrm{mg} \mathrm{g}^{-1}$ & RT & $<0.133 \mathrm{kPa}$ & 199 \\
\hline $\mathrm{CaO} / \mathrm{CaCO}_{3}$ & Siloxane (HMCTS) & $3 \mathrm{mg} \mathrm{g}^{-1}$ & $523 \mathrm{~K}$ & $<0.133 \mathrm{kPa}$ & 199 \\
\hline
\end{tabular}

Most of the work involving $\mathrm{CH}_{4}$ focuses on the removal of contaminants from $\mathrm{CH}_{4}$ rather than on adsorption of $\mathrm{CH}_{4}$ itself. This is predominantly due to the presence of $\mathrm{CO}_{2}$ in natural gas and biogas. In general, $\mathrm{CO}_{2}$ is preferentially adsorbed over $\mathrm{CH}_{4}$, since $\mathrm{CO}_{2}$ has a permanent quadrupole moment, in contrast to the relatively unpolar $\mathrm{C}-\mathrm{H}$ bonds of methane. ${ }^{200}$

As far as the adsorption of $\mathrm{CH}_{4}$ is concerned, several studies show that other materials such as activated carbon, and metal-organic frameworks (MOFs) typically outperform zeolites. ${ }^{13,190,191,201}$ However, some $\mathrm{CH}_{4}$ adsorption studies on natural, ion-exchanged, and acid-treated Turkish zeolite ${ }^{197}$ and mordenite ${ }^{198}$ revealed that their adsorption capacity depends strongly on the nature of the cation present. Furthermore, the observed capacity values decrease with increasing temperature. For Turkish zeolite, Fe-exchanged samples performed best for the adsorption of $\mathrm{CH}_{4}\left(\leq 0.796 \mathrm{mmol} \mathrm{g}{ }^{-1}\right) .{ }^{197}$ Natural mordenite exhibited the highest capacity at low temperatures $\left(0.528 \mathrm{mmol} \mathrm{g}^{-1}\right.$ at $\left.\mathrm{T}=0^{\circ} \mathrm{C}\right)$, whereas Ag-exchanged mordenite showed the highest capacity at higher temperature $\left(0.372 \mathrm{mmol} \mathrm{g}^{-1}\right.$ at $\left.\mathrm{T}=25^{\circ} \mathrm{C}\right)$. For example, boron nitride nanotubes exhibited great promise for the adsorption of $\mathrm{CH}_{4}$ and may thus find applications in $\mathrm{CH}_{4}$ storage systems. ${ }^{202}$

If we consider purification of $\mathrm{CH}_{4}$ sources in the context of adsorbing contaminants, rather that $\mathrm{CH}_{4}$ directly, zeolites such as clinoptilolite, ${ }^{8,107}$ zeolite $13 \mathrm{X},{ }^{108,109}$ and zeolite $4 \mathrm{~A}^{109}$ may be potentially suitable. They show considerable promise for the removal of $\mathrm{CO}_{2}$ from mixed gases, which is particularly useful for biogas processing. Ca-containing clinoptilolite is especially promising in this context with capacities up to $\sim 0.6 \mathrm{mmol} \mathrm{g}^{-1}$, while $\mathrm{Na}$-containing clinoptilolite displays negligible $\mathrm{CH}_{4}$ adsorption, and, accordingly high efficiency. ${ }^{107}$ Meanwhile, $13 \mathrm{X}$ showed an increased capacity for the removal of $\mathrm{CO}_{2}$ in the presence of water vapor, increasing from $14.8 \mathrm{wt} \%$ under dry conditions to $22.0 \mathrm{wt} \%$ under wet conditions. ${ }^{109}$ In general, $13 \mathrm{X}$ (adsorption capacity $\leq 22.0 \mathrm{wt} \%$ ) outperforms zeolite 4A (5.1 wt\%), even though the former suffered from a slower regeneration. ${ }^{109}$ Other purification methods for $\mathrm{CH}_{4}$ from biogas sources include removing siloxanes, $\mathrm{H}_{2} \mathrm{~S}$, and $\mathrm{H}_{2}$. For the adsorption of siloxanes, activated carbon (580 $\mathrm{mg} \mathrm{g}^{-1}$ ) usually outperforms zeolites such as faujasite $\mathrm{NaX}\left(276 \mathrm{mg} \mathrm{g}^{-1}\right) .{ }^{195}$ However, computer simulations suggest that zeolites may work better for the removal of $\mathrm{H}_{2} \mathrm{~S}$ due to preferential selection of $\mathrm{H}_{2} \mathrm{~S}$ by zeolites, and a tendency of $\mathrm{CH}_{4}$ to escape the zeolite. ${ }^{203}$ Conversely, another computer simulation study determined that $\mathrm{H}_{2}$ is able to move better through a zeolite framework than $\mathrm{CH}_{4},{ }^{204}$ thus allowing the two gases to be separated.

A wide variety of silica-based compounds have been investigated for $\mathrm{CH}_{4}$ purification, since such compounds are usually not able to adsorb $\mathrm{CH}_{4}{ }^{13}$ Silicalite was examined for the adsorption of gases from a binary mixture of $\mathrm{CH}_{4} / \mathrm{CF}_{4}$, ${ }^{192}$ while zirconium pillared clays were investigated for the adsorption of $\mathrm{CH}_{4} / \mathrm{CO}_{2}$ mixtures, ${ }^{116}$ and titanosilicates for the simulated adsorption of $\mathrm{CH}_{4} / \mathrm{H}_{2}$ mixtures. ${ }^{205}$ In all the aforementioned studies, the adsorption is unfavorable with respect to $\mathrm{CH}_{4}$, allowing for the adsorption and removal of contaminants, $\mathrm{CF}_{4}, \mathrm{H}_{2}$, and $\mathrm{CO}_{2}$. An extensive study by Sun et al. (1998) investigated silicalite its potential for the adsorption of $\mathrm{C}_{1}$ to $\mathrm{C}_{4}$ alkanes, $\mathrm{CO}_{2}$, and $\mathrm{SF}_{6}{ }^{110}$ The results showed an order of preferred adsorption of $\mathrm{CO}_{2}(3.35$ mmol g$\left.{ }^{-1}\right)>$ methane $\left(2.7 \mathrm{mmol} \mathrm{g}^{-1}\right)>$ ethane $\left(2.65 \mathrm{mmol} \mathrm{g}^{-1}\right)>$ propane $\left(2.05 \mathrm{mmol} \mathrm{g}^{-1}\right)>\mathrm{SF}_{6}\left(2.0 \mathrm{mmol} \mathrm{g}{ }^{-1}\right)>n$-butane $(1.75$ $\mathrm{mmol} \mathrm{g}^{-1}$ ) > isobutene $\left(1.65 \mathrm{mmol} \mathrm{g}^{-1}\right)$. Silica gels were found to be particularly promising for the removal of siloxanes, on account of adsorption capacities in excess of $100 \mathrm{mg} \mathrm{g}^{-1}, 194$ and an ability to simultaneously dry biogas flows. However, the ability of silica to adsorb siloxanes is lost at high temperatures. ${ }^{199}$

The purification of $\mathrm{CH}_{4}$ may also be accomplished by other materials. Several phosphates have also been investigated for purification purposes; silicoaluminophosphates demonstrate a high selectivity for $\mathrm{CO}_{2}$ over $\mathrm{CH}_{4}$, with a maximum adsorption 
capacity of $18.18 \mathrm{mmol} \mathrm{g}^{-1}$ for $\mathrm{CO}_{2}$ compared to a maximum adsorption capacity of $12.30 \mathrm{mmol} \mathrm{g}^{-1}$ for $\mathrm{CH}_{4}{ }^{193} \mathrm{Similarly} \mathrm{CO}_{2}$ was preferentially adsorbed over $\mathrm{CH}_{4}$ by the microporous aluminophosphate, $\mathrm{AIPO} 4-5$, and the mesoporous silicate, MCM-41, with MCM-41 outperforming $\mathrm{ALPO}_{4}-5 .{ }^{102}$ In simulations, a molecular sieve based on zinc phosphate showed better results for separating $\mathrm{H}_{2}$ from a $\mathrm{CH}_{4} / \mathrm{H}_{2}$ mixture than zeolites. ${ }^{204}$ The simulations found that the $\mathrm{H}_{2}$ molecules could move within the zinc phosphate structure between subcages, whereas the $\mathrm{CH}_{4}$ molecules remained stationary within the original subcages. Studies that examine the high-temperature removal of siloxanesfrom biogas by oxides, revealed that among several tested oxides, $\mathrm{Al}_{2} \mathrm{O}_{3}$ performed best with capacities of $310 \mathrm{mg} \mathrm{g}^{-1}$ at $673 \mathrm{~K}$, while other oxides showed low or no adsorption of siloxanes at the same temperature. ${ }^{199}$ The same study revealed that in the absence of $\mathrm{CO}_{2}, \mathrm{MgO}$ and $\mathrm{CaO}$ are able to decompose siloxane; however, the addition of $\mathrm{CO}_{2}$ caused both oxides to fail. Together with the removal of siloxane and $\mathrm{CO}_{2}$, the elimination of $\mathrm{H}_{2} \mathrm{~S}$ from biogas is also important, and for this purpose iron oxides are traditionally used. ${ }^{7,194}$ The use of iron oxides/hydroxides in the form of e.g. steel wool includes several drawbacks, since the presence of water vapor may have a detrimental effect, and the surface areas involved are often insufficient. However, the simultaneous use of iron oxides/hydroxides and red mud greatly increases the surface to volume ratio, and thus improves the performance.

5.2 Hydrogen storage. Molecular hydrogen $\left(\mathrm{H}_{2}\right)$ represents a very attractive alternative fuel source, particularly with regard to vehicular applications. This attractiveness is mostly on account of its high calorific value (142 $\mathrm{MJ} \mathrm{kg}^{-1}$ versus $47 \mathrm{~kJ} \mathrm{kg-}^{1}$ for liquid hydrocarbons), ${ }^{206}$ and the generation of environmentally benign water as the only byproduct. One of the primary obstacles for the use of $\mathrm{H}_{2}$ is its safe and viable storage. ${ }^{206}$ Concerning its safety, $\mathrm{H}_{2}$ naturally adopts a gaseous state underambient conditions and is highly flammable in combination with atmospheric oxygen. For safe storage and transport, $\mathrm{H}_{2}$ accordingly needs to be subdued which is generally achieved by containment under either high pressures (ca. 300-500 psi) ${ }^{207}$ or cryogenic temperatures $(21.2 \mathrm{~K}){ }^{33}$ Regarding other practical viability aspects of $\mathrm{H}_{2}$ storage, the volume of $\mathrm{H}_{2}$ required for a vehicle to travel even short distances currently remains impractically large; conventional hydrogen tanks store $4 \mathrm{~kg}$ of hydrogen with an internal volume of 225 litres. ${ }^{206,208}$ While several methods to circumvent these problems have been reported, none are truly satisfactory, and a few even pose potential dangers. ${ }^{12,207}$ One of the most promising means to compress $\mathrm{H}_{2}$ gas to a practical volume is adsorption, and this is usually achieved via physi-sorption and/or chemi-sorption. 30,33,207 In addition, hydrogen spillover, whereby an adsorbent accepts the hydrogen, which then transfers into an underlying porous host, has garnered considerable attention in the hydrogen storage industry. Although this is outside the scope of this review, there are useful reviews for the interested reader. ${ }^{209-211}$ However, suitable storage host media currently remain elusive. For practical purposes, adsorbents require an adsorption capacity of $\geq 6.5 \mathrm{wt} \%$, a desorption temperature in the range of 333-393 $\mathrm{K}$, low cost, and low toxicity. ${ }^{12,15}$ Adsorption capacities for prospective adsorbents studied for $\mathrm{H}_{2}$ storage are listed in Table 7.

Table 7. Reported adsorption capacities for the encapsulation of $\mathrm{H}_{2}$ in inorganic adsorbents. * indicates where values either could not be obtained, or were not specified (eg. presented as a range); ** indicates theoretical values

\begin{tabular}{|c|c|c|c|c|}
\hline Adsorbent & $\begin{array}{l}\text { Maximum Reported } \\
\text { Capacity }\end{array}$ & Temperature & Pressure & Ref. \\
\hline 10X-zeolite & $4.59 \mathrm{mmol} \mathrm{g}^{-1}$ & $77 \mathrm{~K}$ & $100 \mathrm{kPa}$ & 212 \\
\hline 3A-zeolite & $0.120 \mathrm{mmol} \mathrm{g}^{-1}$ & $77 \mathrm{~K}$ & $100 \mathrm{kPa}$ & 212 \\
\hline 4A-zeolite & $1.80 \mathrm{mmol} \mathrm{g}^{-1}$ & $77 \mathrm{~K}$ & $100 \mathrm{kPa}$ & 212 \\
\hline 5A-zeolite & $3.24 \mathrm{mmol} \mathrm{g}^{-1}$ & $77 \mathrm{~K}$ & $100 \mathrm{kPa}$ & 212 \\
\hline CaA-zeolite & 1.89 wt\% & $77 \mathrm{~K}$ & $1500 \mathrm{kPa}$ & 213 \\
\hline CaX-zeolite & 2.19 wt $\%$ & $77 \mathrm{~K}$ & $1500 \mathrm{kPa}$ & 213 \\
\hline CaY-zeolite & 1.82 wt $\%$ & $77 \mathrm{~K}$ & $1500 \mathrm{kPa}$ & 213 \\
\hline CdA-zeolite & 1.14 wt $\%$ & $77 \mathrm{~K}$ & $1500 \mathrm{kPa}$ & 214 \\
\hline CdRHO-zeolite & 0.25 wt $\%$ & $543 \mathrm{~K}$ & $1500 \mathrm{kPa}$ & 214 \\
\hline CdX-zeolite & 1.42 wt $\%$ & $77 \mathrm{~K}$ & $1500 \mathrm{kPa}$ & 214 \\
\hline CdY-zeolite & 1.47 wt\% & $77 \mathrm{~K}$ & $1500 \mathrm{kPa}$ & 214 \\
\hline CsX-zeolite & 1.32 wt $\%$ & $77 \mathrm{~K}$ & $1500 \mathrm{kPa}$ & 213 \\
\hline CsY-zeolite & 1.33 wt\% & $77 \mathrm{~K}$ & $1500 \mathrm{kPa}$ & 213 \\
\hline CuX-zeolite & 0.25 wt $\%$ & $543 \mathrm{~K}$ & $1500 \mathrm{kPa}$ & 214 \\
\hline MgA-zeolite & ca. 1.0 wt\% & $77 \mathrm{~K}$ & $1500 \mathrm{kPa}$ & 213 \\
\hline MgA-zeolite & 1.19 wt\% & $77 \mathrm{~K}$ & $1500 \mathrm{kPa}$ & 214 \\
\hline H-OFF zeolite & 1.75 wt $\%$ & $77 \mathrm{~K}$ & $1600 \mathrm{kPa}$ & 189 \\
\hline KX-zeolite & 1.96 wt\% & $77 \mathrm{~K}$ & $1500 \mathrm{kPa}$ & 213 \\
\hline
\end{tabular}




\begin{tabular}{|c|c|c|c|c|}
\hline Li-ABW zeolite & $1.02 \mathrm{wt} \%$ & $77 \mathrm{~K}$ & $1600 \mathrm{kPa}$ & 189 \\
\hline KY-zeolite & 1.87 wt\% & $77 \mathrm{~K}$ & $1500 \mathrm{kPa}$ & 213 \\
\hline MgRho-zeolite & 1.75 wt $\%$ & $77 \mathrm{~K}$ & $1500 \mathrm{kPa}$ & 213 \\
\hline MgX-zeolite & $1.62 \mathrm{wt} \%$ & $77 \mathrm{~K}$ & $1500 \mathrm{kPa}$ & 213 \\
\hline MgX-zeolite & 1.61 wt $\%$ & $77 \mathrm{~K}$ & $1500 \mathrm{kPa}$ & 214 \\
\hline MgX-zeolite & ca. 2.5 wt\% & $35 \mathrm{~K}$ & ca. $750 \mathrm{kPa}$ & 215 \\
\hline MgY-zeolite & 1.76 wt\% & $77 \mathrm{~K}$ & $1500 \mathrm{kPa}$ & 213 \\
\hline MgY-zeolite & $1.74 \mathrm{wt} \%$ & $77 \mathrm{~K}$ & $1500 \mathrm{kPa}$ & 214 \\
\hline NaA-zeolite & 1.54 wt $\%$ & $77 \mathrm{~K}$ & $1510 \mathrm{kPa}$ & 189 \\
\hline NaA-zeolite & 1.54 wt\% & $77 \mathrm{~K}$ & $1500 \mathrm{kPa}$ & 213 \\
\hline NaA-zeolite & 1.54 wt\% & $77 \mathrm{~K}$ & $1500 \mathrm{kPa}$ & 214 \\
\hline NaCsRHO-zeolite & 0.20 wt $\%$ & $543 \mathrm{~K}$ & $1500 \mathrm{kPa}$ & 214 \\
\hline Na-LEV zeolite & 2.07 wt\% & $77 \mathrm{~K}$ & $1600 \mathrm{kPa}$ & 189 \\
\hline Na-MAZ zeolite & 1.64 wt\% & $77 \mathrm{~K}$ & $1600 \mathrm{kPa}$ & 189 \\
\hline NaX-zeolite & 1.74 wt $\%$ & $77 \mathrm{~K}$ & $1490 \mathrm{kPa}$ & 189 \\
\hline NaX-zeolite & 1.79 wt $\%$ & $77 \mathrm{~K}$ & $1500 \mathrm{kPa}$ & 213 \\
\hline NaX-zeolite & 1.79 wt $\%$ & $77 \mathrm{~K}$ & $1500 \mathrm{kPa}$ & 214 \\
\hline NaX-zeolite & ca. $16 \mathrm{mmol} \mathrm{g}^{-1}$ & $30 \mathrm{~K}$ & $5500 \mathrm{kPa}$ & 216 \\
\hline NaX-zeolite & ca. 4 wt\% & $35 \mathrm{~K}$ & ca. $500 \mathrm{kPa}$ & 215 \\
\hline NaX-zeolite & $6.92 \mathrm{mmol} \mathrm{g}^{-1}(1.37 \mathrm{wt} \%)$ & $77 \mathrm{~K}$ & $966 \mathrm{kPa}$ & 217 \\
\hline NaY-zeolite & 1.81 wt $\%$ & $77 \mathrm{~K}$ & $1500 \mathrm{kPa}$ & 213 \\
\hline NaY-zeolite & $1.81 \mathrm{wt} \%$ & $77 \mathrm{~K}$ & $1500 \mathrm{kPa}$ & 214 \\
\hline RbX-zeolite & 1.46 wt $\%$ & $77 \mathrm{~K}$ & $1500 \mathrm{kPa}$ & 213 \\
\hline RbY-zeolite & $1.48 w t \%$ & $77 \mathrm{~K}$ & $1500 \mathrm{kPa}$ & 213 \\
\hline SrA-zeolite & ca. 1.6 wt $\%$ & $77 \mathrm{~K}$ & $1500 \mathrm{kPa}$ & 213 \\
\hline SrX-zeolite & 1.68 wt\% & $77 \mathrm{~K}$ & $1500 \mathrm{kPa}$ & 213 \\
\hline SrY-zeolite & 1.59 wt\% & $77 \mathrm{~K}$ & $1500 \mathrm{kPa}$ & 213 \\
\hline Y-zeolite & $4.60 \mathrm{mmol} \mathrm{g}^{-1}$ & $77 \mathrm{~K}$ & $100 \mathrm{kPa}$ & 212 \\
\hline ZnX-zeolite & ca. 1.0 wt\% & $35 \mathrm{~K}$ & ca. $750 \mathrm{kPa}$ & 215 \\
\hline $\begin{array}{l}\text { HBBN-1 (micro/mesoporous boron nitride } \\
\text { material) }\end{array}$ & $5.6 w t \%$ & $298 \mathrm{~K}$ & $3000 \mathrm{kPa}$ & 65 \\
\hline Bamboo boron nitride nanotubes & $2.6 w t \%$ & $293 \mathrm{~K}$ & ca. $10000 \mathrm{kPa}$ & 218 \\
\hline Boron nitride hollow spheres & 4.07 wt $\%$ & $298 \mathrm{~K}$ & $10000 \mathrm{kPa}$ & 62 \\
\hline $\mathrm{Li}_{2} \mathrm{Ti}\left(\mathrm{BH}_{4}\right)_{5} * 5 \mathrm{NH}_{3}$ & $15.8 \mathrm{wt} \%$ & $*$ & $100 \mathrm{kPa}$ & 219 \\
\hline Multiwall boron nitride nanotubes & $1.8 \mathrm{wt} \%$ & $293 \mathrm{~K}$ & ca. $10000 \mathrm{kPa}$ & 218 \\
\hline $\mathrm{Ti}\left(\mathrm{BH}_{4}\right)_{3} * 3 \mathrm{NH}_{3}$ & 14 wt\% & $*$ & $100 \mathrm{kPa}$ & 219 \\
\hline $\mathrm{Ti}\left(\mathrm{BH}_{4}\right)_{3} * 5 \mathrm{NH}_{3}$ & $13.4 \mathrm{wt} \%$ & $*$ & $100 \mathrm{kPa}$ & 219 \\
\hline $\mathrm{Ti}\left(\mathrm{BH}_{4}\right)_{3} * 5 \mathrm{NH}_{3}+\mathrm{LiBH}_{4}$ & $15.0 \mathrm{wt} \%$ & $*$ & $100 \mathrm{kPa}$ & 219 \\
\hline Ti-diboride nanotubes & $5.5 \mathrm{wt} \% * *$ & $*$ & $*$ & 220 \\
\hline CMK-3 & $4.31 \mathrm{mmol} \mathrm{g}^{-1}$ & $77 \mathrm{~K}$ & $100 \mathrm{kPa}$ & 212 \\
\hline $\mathrm{Mg}_{70} \mathrm{Al}_{10} \mathrm{Fe}_{20}$ & 4.13 wt $\%$ & $473 \mathrm{~K}$ & $300 \mathrm{kPa}$ & 221 \\
\hline $\mathrm{Mg}_{70} \mathrm{Al}_{12} \mathrm{Fe}_{18}$ & $3.5 w t \%$ & $473 \mathrm{~K}$ & $300 \mathrm{kPa}$ & 221 \\
\hline $\mathrm{Mg}_{70} \mathrm{Al}_{15} \mathrm{Ti}_{15}$ & ca. $4.5 \mathrm{wt} \%$ & $473 \mathrm{~K}$ & $300 \mathrm{kPa}$ & 221 \\
\hline $\mathrm{Mg}_{70} \mathrm{Al}_{30}$ & 4 wt\% & $473 \mathrm{~K}$ & $300 \mathrm{kPa}$ & 221 \\
\hline $\mathrm{Mg}_{70} \mathrm{Fe}_{15} \mathrm{Ti}_{15}$ & ca. 4 wt\% & $473 \mathrm{~K}$ & $300 \mathrm{kPa}$ & 221 \\
\hline $\mathrm{Mg}_{70} \mathrm{Fe}_{30}$ & $4.8 w t \%$ & $473 \mathrm{~K}$ & $300 \mathrm{kPa}$ & 221 \\
\hline $\mathrm{Mg}_{75} \mathrm{Ti}_{25}$ & $5.2 w t \%$ & $473 \mathrm{~K}$ & $300 \mathrm{kPa}$ & 221 \\
\hline $\mathrm{Mg}_{85} \mathrm{Al}_{7.5} \mathrm{Ti}_{7.5}$ & ca. 5.5 wt\% & $473 \mathrm{~K}$ & $300 \mathrm{kPa}$ & 221 \\
\hline $\mathrm{Mg}_{85} \mathrm{Fe}_{7.5} \mathrm{Ti}_{7.5}$ & ca. 5 wt\% & $473 \mathrm{~K}$ & $300 \mathrm{kPa}$ & 221 \\
\hline 2.5 $\mathrm{LiH}+\mathrm{Si}$ mixture & $5.0 w t \%$ & $749 \mathrm{~K}$ & $74 \mathrm{kPa}$ & 222 \\
\hline 2Mg-Ni-Al hydrotalcite mixed oxide & $38.69 \mathrm{mg} \mathrm{g}^{-1}$ & $303 \mathrm{~K}$ & $80 \mathrm{kPa}$ & 223 \\
\hline Mg-Al hydrotalcite mixed oxide & $22.40 \mathrm{mg} \mathrm{g}^{-1}$ & $303 \mathrm{~K}$ & $80 \mathrm{kPa}$ & 223 \\
\hline Mg-2Ni-Al hydrotalcite mixed oxide & $28.80 \mathrm{mg} \mathrm{g}^{-1}$ & $303 \mathrm{~K}$ & $80 \mathrm{kPa}$ & 223 \\
\hline $\mathrm{MgH}_{2} / \mathrm{Si}$ system & $5.0 \mathrm{wt} \% * *$ & $423 \mathrm{~K}$ & $10000 \mathrm{kPa}$ & 222 \\
\hline $\mathrm{Ni}$-Al hydrotalcite mixed oxide & $20.40 \mathrm{mg} \mathrm{g}^{-1}$ & $303 \mathrm{~K}$ & $80 \mathrm{kPa}$ & 223 \\
\hline SBA-15 & $2.33 \mathrm{mmol} \mathrm{g}^{-1}$ & $77 \mathrm{~K}$ & $100 \mathrm{kPa}$ & 212 \\
\hline
\end{tabular}


In the context of the physisorption of $\mathrm{H}_{2}$, zeolites have been investigated extensively, especially with respect to the effects of ion exchange within zeolites on $\mathrm{H}_{2}$ uptake. However, alternative adsorbent modification strategies have also been examined. Shi et al. (2012), 217 for example, have probed the effects of modifying zeolite NaX with a monolayer dispersion of $\mathrm{MnO}_{2}$. The results obtained revealed that this moderate extent of adsorbent modification induced a $\mathrm{H}_{2}$ capacity increase of up to $30 \%$ at room temperature, while it had little or worse consequences at low temperature $(\mathrm{T}=77 \mathrm{~K})$. In general, even after i on exchange or modifications, zeolites suffer from low uptake capacity, and exhibit an optimal window of operation at low temperatures $(\mathrm{T} \approx 77-295 \mathrm{~K}$ ). Furthermore, several studies concluded that the precise pore size is a highly important factor for physi-sorption, since $\mathrm{H}_{2}$ shows a preference for adsorption in pores with channel sizes close to the kinetic diameter of the $\mathrm{H}_{2}$ molecule. ${ }^{189,224,225}$ However, the pore size must be controlled carefully in order to prevent pore blocking. ${ }^{213}$

Given this adsorption preference of $\mathrm{H}_{2}$ for hosts with relatively small pore sizes, nanotubes (NTs) of various compositions have also garnered substantial scientific interest. Inorganic NTs investigated include $\mathrm{TiO}_{2},{ }^{226}$ boron nitrides, ${ }^{218}$ and metal-diborides. ${ }^{220}$ These adsorbents are attractive due to their ease of fabrication, the effective reversibility of the adsorption, and an operational window that includes ambient conditions. However, the ir observed adsorption capacities (2-5wt\%) are usually insufficient to merit practical applications in motor vehicles. Investigations into the shape, length, and wall thickness of such NTs revealed that their specific physical nature is important. For example, Ma et al. (2002) discovered that multiwalled bambooshaped boron nitride NTs exhibit an adsorption capacity that is $100 \%$ enhanced, relative to conventional NTs. ${ }^{218}$ Lian et al. (2012) explored how the shell thickness of hollow boron nitride spheres affected $\mathrm{H}_{2}$ uptake. ${ }^{62}$ The results demonstrated that ultrathin $(1-3 \mathrm{~nm})$ shells delivered better performance ( $4.07 \mathrm{wt} \%)$ than thicker shells ( $8-10 \mathrm{~nm} ; 2.31 \mathrm{wt} \%)$.

Arguably, the highest proportion of research on $\mathrm{H}_{2}$ storage with inorganic sorbents is focused on chemi-sorption, involving hydrides. Several reviews specifically target individual types of hydrides. ${ }^{12,14-16,30,31}$ In general, hydrides provide excellent adsorption capacities, albeit at temperatures that are far too high for practical applications. Moreover, several types of hydrides, such as borohydrides and $\mathrm{Mg}$-based hydrides, exhibit very slow adsorption kinetics, have limitations with respect to reversibility, or produce undesirable byproducts. Strategies to improve the overall performance of hydrides incl ude the use of catalysts, ${ }^{31,227}$ modification of the hydrides by hydrolysis or thermolysis, ${ }^{31}$ destabilization with Si, ${ }^{222}$ ball-milling, ${ }^{12}$ or doping. ${ }^{12}$ However, the synthesis of new bespoke classes of hydrides should offer even more promising results. For example, Weidentaler et al. (2009) 228 discovered that the stability of rare-earth aluminum hydrides depends on the nature of the cation, whereby use of neodymium rather than lanthanum decreases the adsorbent stability markedly. These results led the authors to speculate that the chemisorption of $\mathrm{H}_{2}$ in these compounds might be reversible at temperatures lower than those of other types of hydrides, rendering such hydrides a potentially new class of intermediate-temperature hydrides. Furthermore, investigations on $\mathrm{Ti}\left(\mathrm{BH}_{4}\right)_{3} \cdot 3 \mathrm{NH}_{3}, \mathrm{Ti}\left(\mathrm{BH}_{4}\right)_{3} \cdot 5 \mathrm{NH}_{3}$, and $\mathrm{Li} 2 \mathrm{Ti}_{2}\left(\mathrm{BH}_{4}\right)_{5} \cdot 5 \mathrm{NH}_{3}$ by Yuan et al. $(2012)^{219}$ revealed that high $\mathrm{H}_{2}$ adsorption capacities below $\mathrm{T}=$ $300{ }^{\circ} \mathrm{C}$ are possible. Especially noteworthy is the continuous release of $\mathrm{H}_{2}$ by $\mathrm{Li} 2 \mathrm{Ti}_{(}\left(\mathrm{BH}_{4}\right)_{5} \cdot 5 \mathrm{NH}_{3}$ and $\mathrm{Ti}\left(\mathrm{BH}_{4}\right)_{3} \cdot 3 \mathrm{NH}_{3}$ at a constant temperature of $\mathrm{T}=100{ }^{\circ} \mathrm{C}$, with $\mathrm{H}_{2}$ adsorption capacities of $\sim 9$ wt\%, which fulfills the requirements for vehicular applications. Even though extensive studies on the regeneration behavior of these adsorbents still need to be carried out, these preliminary reports hold good promise.

Furthermore, mixed oxides have been explored for $\mathrm{H}_{2}$ storage applications. Among these, $\mathrm{Mg}$-containing oxides have received particular interest, while $\mathrm{Al}-, \mathrm{Ni}-$, and Ti-containing oxides have also attracted attention. ${ }^{223,229}$ However, in general, such mixed oxides are associated with several drawbacks, including uptake capacity values that are too low for operation under ambient conditions, low or slowly degrading adsorption/desorption kinetics. In addition to which, there are large discrepancies between theoretically expected and experimentally observed adsorption capacities.

\section{Conclusions}

Removing pollutants from the environment, alternative fuel sources, and nuclear waste management are among the most pressing, and complex problems that currently face humanity. In the not-too-distant future, preserving water resources and recycling wastewater may become even more important. The control of airborne pollutants will require increasing attention in order to keep the impending threat of climate change at bay; although this problem will hopefully be ameliorated by a switch to cleaner fuel sources. The ever-increasing global energy demands nonetheless mean that nuclear energy needs to remain in the 
portfolio of power sources until a better solution can be discovered; this renders the processing of nuclear waste an ongoing obstacle. For all of these concerns, host-guest encapsulation using inorganic adsorbents often provides an effective, simple, and inexpensive solution.

Water treatment often relies on activated carbons to act as adsorbents for the removal of dyes and heavy metal ions; although, these adsorbents are generally very costly. Especially modified, composite, and synthetic zeolites promise great potential alternatives, particularly for the removal of heavy metal ions. Clays, on the other hand, show promising potential for removal of dyes. Even though adsorbents originating from industrial waste products have been extensively investigated due to their low cost, their overall performance is typically below that of activated carbon or zeolites, particularly for the removal of dyes. However, some industrial by-products hold promise for the removal of heavy metal ions. ${ }^{6}$ The greatest challenge for the use of adsorbents in the context of water treatment is the great level of variety in contaminants, which prevents the use of a single compound for a general cleaning. Further investigations into composites or modified compounds may help reduce the number of adsorbents needed, but this will probably occur at the expense of higher costs.

Air pollution control measures largely use liquid solutions for the capture of $\mathrm{CO}_{2}$, or activated carbons for the trapping of VOCs. Zeolites loaded with amines show promising potential for the encapsulation of $\mathrm{CO}_{2}$, while dealuminated zeolites may be useful for the trapping of $\mathrm{SO}_{2}$. Overall, inorganic host media did not perform well in the removal of VOCs, which is often due to the competition of water for reaction sites. Nonetheless, the use of dry VOC streams may find some zeolites and clays effective. Operational effectiveness continues to pose difficulties in practice, due to high environmental temperatures within flue streams, which give inorganics an edge over activated carbons on account of the generally better thermal stability.

Composite materials including inorganic components may be effective for the removal of radioactive waste, particularly for the removal of trace amounts, which is promising for contamination clean-up. For the encapsulation of nuclear waste, borosilicate glasses are mostly used, even though they are less effective at containing actinides. Some phosphate glasses are able to incorporate actinides better, and show better durability and leach resistance than the borosilicates. Moreover, glass-ceramics are, in general, easier to fabricate than ceramics, more durable than glass, and can incorporate high loadings of guests. Utilizing spent $\mathrm{UO}_{2}$ pellets as waste forms is ineffective. Even though the variety of radionuclides requiring immobilization poses a primary obstacle, the use of multi-phase materials, such as the glass-ceramics, may allow some radionuclide species to reside in the crystalline phases, and others to remain in the glass; thus, allowing the encapsulating of more species than in a single-phase material.

Alternative fuels such as $\mathrm{CH}_{4}$ and $\mathrm{H}_{2}$ provide an additional challenge to environmental management: they require the possibility of a controlled release from the guest material, as well as storage in the host medium. $\mathrm{CH}_{4}$ fuel sources (predominantly natural gas or biogas) also need to be purified prior to use. $\mathrm{CH}_{4}$ generally adsorbs well into inorganic hosts, which means potential applications for inorganic adsorbents may arise in the context of purifying $\mathrm{CH}_{4}$ from biogas sources. Zeolites work well to purify $\mathrm{CH}_{4}$ via the removal of $\mathrm{CO}_{2}$ contaminants from biogas, while silica gels remove siloxanes well. In the context of $\mathrm{H}_{2}$ as an alternative fuel, hydrides, particularly borohydrides and $\mathrm{Mg}$-based hydrides, offer some promise for $\mathrm{H}_{2}$ storage, but suffer from slow adsorption/desorption kinetics and high desorption temperatures. In contrast, zeolites operate as potential hosts for $\mathrm{H}_{2}$ at acceptable temperatures, but fall short in storage capacities. Finding suitable $\mathrm{H}_{2}$ storage materials should require further improvements in capacity, kinetics, and/or thermodynamics.

In summary, inorganic host materials may be used for a wide variety of environmentally beneficial applications. For many of these applications, encapsulation provides a safer, more effective, and cheaper means of protecting the world around us.

\section{Acknowledgements}

J.M.C. thanks the Royal Commission of the Great Exhibition 1851 for the 2014 Fellowship in Design, hosted by Argonne National Laboratory where work done was supported by DOE Office of Science, Office of Basic Energy Scie nces, under contract No. DEAC02-06CH11357.

\section{References}


E. Forgacs, T. Cserháti and G. Oros, Environ. Int., 2004, 30, 953-971.

A. Adak, M. Bandyopadhyay and A. Pal, Sep. Purif. Technol., 2005, 44, 139-144.

V. K. Gupta and Suhas, J. Environ. Manage., 2009, 90, 2313-2342.

F. I. Khan and A. Kr. Ghoshal, J. Loss Prev. Process Ind. , 2000, 13, 527-545.

M. Hua, S. Zhang, B. Pan, W. Zhang, L. Lv and Q. Zhang, J. Hazard. Mater., 2012, 211-212, 317-331.

T. A. Kurniawan, G. Y. S. Chan, W. H. Lo and S. Babel, Sci. Total Environ., 2006, 366, 409-426.

E. Ryckebosch, M. Drouillon and H. Vervaeren, Biomass and Bioenergy, 2011, 35, 1633-1645.

M. W. Ackley, S. U. Rege and H. Saxena, Microporous Mesoporous Mater. , 2003, 61, 25-42.

S. Choi, J. H. Drese and C. W. Jones, ChemSusChem, 2009, 2, 796-854.

F. Rezaei, A. A. Rownaghi, S. Monjezi, R. P. Lively and C. W. Jones, Energy \& Fuels, 2015, 29, 5467-5486.

E. Drabarek, T. I. McLeod, J. V. Hanna, C. S. Griffith and V. Luca, J. Nucl. Mater., 2009, 384, 119-129.

I. P. Jain, P. Jain and A. Jain, J. Alloys Compd., 2010, 503, 303-339.

V. Menon and S. Komarneni, J. Porous Mater., 1998, 5, 43-58.

S.-I. Orimo, Y. Nakamori, J. R. Eliseo, A. Züttel and C. M. Jensen, Chem. Rev., 2007, 107, 4111-4132.

B. Sakintuna, F. Lamaridarkrim and M. Hirscher, Int. J. Hydrogen Energy, 2007, 32, 1121-1140.

L. Zhou, Renew. Sustain. Energy Rev., 2005, 9, 395-408.

L. P. Hatch, Am. Sci., 1953, 41, 410-421.

V. M. Efremenkov, IAEA Bull., 1989, 37-42.

I. W. Donald, B. L. Metcalfe and R. N. J. Taylor, J. Mater. Sci., 1997, 32, 5851-5887.

R. O. Abdel Rahman, H. A. Ibrahium and Y. T. Hung, Water (Switzerland), 2011, 3, 551-565.

P. Misaelides, Microporous Mesoporous Mater., 2011, 144, 15-18.

D. Mohan and C. U. Pittman, J. Hazard. Mater., 2007, 142, 1-53.

S. Wang and Y. Peng, Chem. Eng. J., 2010, 156, 11-24.

M. Harper, J. Chromatogr. A, 2000, 885, 129-151.

K. Dettmer and W. Engewald, Anal. Bioanal. Chem., 2002, 373, 490-500.

Q. Wang, J. Luo, Z. Zhong and A. Borgna, Energy Environ. Sci., 2011, 4, 42-55.

Y. Mathieu, L. Tzanis, M. Soulard, J. Patarin, M. Vierling and M. Molière, Fuel Process. Technol., 2013, 114, 81-100.

Y. Liu, T. M. Bisson, H. Yang and Z. Xu, Fuel Process. Technol., 2010, 91, 1175-1197.

M. Ajhar, M. Travesset, S. Yüce and T. Melin, Bioresour. Technol., 2010, 101, 2913-2923.

L. George and S. K. Saxena, Int. J. Hydrogen Energy, 2010, 35, 5454-5470.

T. Umegaki, J.-M. Yan, X.-B. Zhang, H. Shioyama, N. Kuriyama and Q. Xu, Int. J. Hydrogen Energy, 2009, 34, $2303-2311$. 
X. Zhao and L. Ma, Int. J. Hydrogen Energy, 2009, 34, 4788-4796.

A. Züttel, Mater. Today, 2003, 6, 24-33.

R. C. Ewing, Proc. Natl. Acad. Sci. U. S. A., 1999, 96, 3432-9.

R. C. Ewing, Can. Mineral., 2001, 39, 697-715.

R. C. Ewing and L. Wang, Rev. Mineral. Geochemistry, 2002, 48, 673-699.

M. I. Ojovan and W. E. Lee, Metall. Mater. Trans. A Phys. Metall. Mater. Sci., 2011, 42, 837-851.

M. J. Plodinec, Glas. Technol. J. Glas. Sci. Technol. Part A, 2000, 41, 186-192.

R. D. Rawlings, J. P. Wu and A. R. Boccaccini, J. Mater. Sci., 2006, 41, 733-761.

R. C. Ewing, W. J. Weber and F. W. Clinard, Prog. Nucl. Energy, 1995, 29, 63-127.

W. J. Weber, R. C. Ewing, C. R. A. Catlow, T. D. de la Rubia, L. W. Hobbs, C. Kinoshita, H. Matzke, A. T. Motta, M. Nastasi, E. K. H. Salje, E. R. Vance and S. J. Zinkle, J. Mater. Res., 1998, 13, 1434-1484.

A. K. Pabby, Membr. Technol., 2008, 2008, 9-13.

A. E. Ringwood, Mineral. Mag., 1985, 49, 159-176.

W. J. Weber, A. Navrotsky, S. Stefanovsky, E. R. Vance and E. Vernaz, 2009, 34.

B. Benguella and A. Yacouta-Nour, Desalination, 2009, 235, 276-292.

G. San Miguel, S. D. Lambert and N. J. D. Graham, J. Chem. Technol. Biotechnol., 2006, 81, 1685-1696.

P. V. Messina and P. C. Schulz, J. Colloid Interface Sci., 2006, 299, 305-320.

B. Armağan, M. Turan and M. S. Çelik, Desalination, 2004, 170, 33-39.

V. K. Gupta, Suhas, I. Ali and V. K. Saini, Ind. Eng. Chem. Res., 2004, 43, 1740-1747.

A. K. Jain, V. K. Gupta, A. Bhatnagar and Suhas, Sep. Sci. Technol., 2003, 38, 463-481.

X. Jin, M. Q. Jiang, X. Q. Shan, Z. G. Pei and Z. Chen, J. Colloid Interface Sci., 2008, 328, 243-247.

S.-F. Kang, C.-H. Liao and S.-T. Po, Chemosphere, 2000, 41, 1287-1294.

C. Namasivayam and D. J. S. E. Arasi, Chemosphere, 1997, 34, 401-417.

C. Namasivayam, R. Jeyakumar and R. T. Yamuna, Science (80-. )., 1994, 14, 643-648.

A. S. Özcan and A. Özcan, J. Colloid Interface Sci., 2004, 276, 39-46.

M. A. Rauf, S. M. Qadri, S. Ashraf and K. M. Al-Mansoori, Chem. Eng. J., 2009, 150, 90-95.

S. S. Tahir and N. Rauf, Chemosphere, 2006, 63, 1842-1848.

Y.-S. Choi and J.-H. Cho, Environ. Technol., 1996, 17, 1169-1180.

I. M. Banat, P. Nigam, D. Singh and R. Marchant, Bioresour. Technol., 1996, 58, 217-227.

A. K. Jain, V. K. Gupta, A. Bhatnagar and Suhas, J. Hazard. Mater., 2003, 101, 31-42.

M. N. Ahmed and R. N. Ram, Environ. Pollut., 1992, 77, 79-86. 
G. Lian, X. Zhang, S. Zhang, D. Liu, D. Cui and Q. Wang, Energy Environ. Sci., 2012, 5, 7072.

S. Wang, H. Li and L. Xu, J. Colloid Interface Sci., 2006, 295, 71-78.

O. Ozdemir, B. Armagan, M. Turan and M. S. Çelik, Dye. Pigment., 2004, 62, 49-60.

J. Li, J. Lin, X. Xu, X. Zhang, Y. Xue, J. Mi, Z. Mo, Y. Fan, L. Hu, X. Yang, J. Zhang, F. Meng, S. Yuan and C. Tang, Nanotechnology, 2013, 24, 155603.

S. Wang, Y. Boyjoo, A. Choueib and Z. H. Zhu, Water Res., 2005, 39, 129-138.

S. Wang and H. Li, Microporous Mesoporous Mater., 2006, 97, 21-26.

S. Wang, H. Li, S. Xie, S. Liu and L. Xu, Chemosphere, 2006, 65, 82-87.

S. Wang and Z. H. Zhu, J. Hazard. Mater., 2006, 136, 946-952.

V. Meshko, L. Markovska, M. Mincheva and A. E. Rodrigues, Water Res., 2001, 35, 3357-3366.

S. Sohrabnezhad and A. Pourahmad, Desalination, 2010, 256, 84-89.

G. S. Gupta, S. P. Shukla, G. Prasad and V. N. Singh, Environ. Technol., 1992, 13, 925-936.

J. Huang, Y. Liu, Q. Jin, X. Wang and J. Yang, J. Hazard. Mater., 2007, 143, 541-548.

S. K. Alpat, Ö. Özbayrak, Ş. Alpat and H. Akçay, J. Hazard. Mater., 2008, 151, 213-220.

S. D. Lambert, N. J. D. Graham, C. J. Sollars and G. D. Fowler, in Water Science and Technology, 1997, vol. 36, pp. 173180.

L. Järup, Br. Med. Bull., 2003, 68, 167-182.

G. W. Bryan and W. J. Langston, Environ. Pollut., 1992, 76, 89-131.

R. Chitrakar, H. Kanoh, Y. Miyai and K. Ooi, Ind. Eng. Chem. Res., 2001, 40, 2054-2058.

K. S. Chung, J. C. Lee, W. K. Kim, S. B. Kim and K. Y. Cho, J. Memb. Sci., 2008, 325, 503-508.

S. Babel and T. A. Kurniawan, J. Hazard. Mater., 2003, 97, 219-243.

S. E. Bailey, T. J. Olin, R. M. Bricka and D. D. Adrian, Water Res., 1999, 33, 2469-2479.

M. Szlachta, V. Gerda and N. Chubar, J. Colloid Interface Sci., 2012, 365, 213-221.

E. Gutiérrez-Segura, M. Solache-Ríos, A. Colín-Cruz and C. Fall, Water, Air, Soil Pollut., 2014, 225, 1943.

Y. S. Ok, J. E. Yang, Y. S. Zhang, S. J. Kim and D. Y. Chung, J. Hazard. Mater., 2007, 147, 91-96.

S. K. Ouki and M. Kavannagh, Waste Manag. Res., 1997, 15, 383-394.

E. Erdem, N. Karapinar and R. Donat, J. Colloid Interface Sci., 2004, 280, 309-314.

K. S. Hui, C. Y. H. Chao and S. C. Kot, J. Hazard. Mater., 2005, 127, 89-101.

T. Motsi, N. A. Rowson and M. J. H. Simmons, Int. J. Miner. Process., 2009, 92, 42-48.

J. Jurng, T. G. Lee, G. W. Lee, S. J. Lee, B. H. Kim and J. Seier, Chemosphere, 2002, 47, 907-913.

N. I. Chubar, V. A. Kanibolotskyy, V. V. Strelko, G. G. Gallios, V. F. Samanidou, T. O. Shaposhnikova, V. G. Mil grandt and I. Z. Zhuravlev, Colloids Surfaces A Physicochem. Eng. Asp., 2005, 255, 55-63. 
W. Huang, S. Wang, Z. Zhu, L. Li, X. Yao, V. Rudolph and F. Haghseresht, J. Hazard. Mater., 2008, 158, 35-42. M.-H. Dai and S.-C. Wu, Sep. Sci., 1975, 10, 633-638.

R. Donat, J. Chem. Thermodyn., 2009, 41, 829-835.

S. K. Pitcher, R. C. T. Slade and N. I. Ward, Sci. Total Environ., 2004, 334-335, 161-166.

M. J. Cairns, T. Borrmann, W. H. Höll and J. H. Johnston, Microporous Mesoporous Mater., 2006, 95, 126-134.

E. Díaz, S. Ordóñez, A. Vega and J. Coca, J. Chromatogr. A, 2004, 1049, 139-146.

H. Deng, H. Yi, X. Tang, Q. Yu, P. Ning and L. Yang, Chem. Eng. J., 2012, 188, 77-85.

S. Karapati, T. Giannakopoulou, N. Todorova, N. Boukos, S. Antiohos, D. Papageorgiou, E. Chaniotakis, D. Dimotikali and C. Trapalis, Appl. Surf. Sci., 2014, 319, 29-36.

M. Nagao, T. Yoshii, Y. Namekata, S. Teranishi, M. Sano, A. Tomita and T. Hibino, Solid State lonics, 2008, 179, 16551661.

R. S. Franchi, P. J. E. Harlick and A. Sayari, Ind. Eng. Chem. Res., 2005, 44, 8007-8013.

I. C. Marcu and I. Sandulescu, J. Serbian Chem. Soc., 2004, 69, 563-569.

C. A. Koh, T. Montanari, R. I. Nooney, S. F. Tahir and R. E. Westacott, Langmuir, 1999, 15, 6043-6049.

Z. Yong, V. Mata and A. E. Rodrigues, J. Chem. Eng. Data, 2000, 45, 1093-1095.

X. Xu, C. Song, J. M. Andresen, B. G. Miller and A. W. Scaroni, Energy and Fuels, 2002, 16, 1463-1469.

J. Zhao, F. Simeon, Y. Wang, G. Luo and T. A. Hatton, RSC Adv., 2012, 2, 6509.

P. Bollini, N. A. Brunelli, S. A. Didas and C. W. Jones, Ind. Eng. Chem. Res., 2012, 51, 15153-15162.

G. Aguilar-Armenta, G. Hernandez-Ramirez, E. Flores-Loyola, A. Ugarte-Castaneda, R. Silva-Gonzalez, C. TabaresMunoz, A. Jimenez-Lopez and E. Rodriguez-Castellon, J. Phys. Chem. B, 2001, 105, 1313-1319.

S. Cavenati, C. A. Grande and A. E. Rodrigues, J. Chem. Eng. Data, 2004, 49, 1095-1101.

T. Montanari, E. Finocchio, E. Salvatore, G. Garuti, A. Giordano, C. Pistarino and G. Busca, Energy, 2011, 36, 314-319.

M. S. Sun, D. B. Shah, H. H. Xu and O. Talu, J. Phys. Chem. B, 1998, 102, 1466-1473.

Z. Li, N. Cai, Y. Huang and H. Han, Energy \& Fuels, 2005, 19, 1447-1452.

H. Lu and P. G. Smirniotis, Ind. Eng. Chem. Res., 2009, 48, 5454-5459.

A. Czyzewski, J. Kapica, D. Moszyński, R. Pietrzak and J. Przepiórski, Chem. Eng. J., 2013, 226, 348-356.

J. Ida and Y. S. Lin, Environ. Sci. Technol., 2003, 37, 1999-2004.

M. Khokhani, R. B. Khomane and B. D. Kulkarni, J. Sol-Gel Sci. Technol., 2012, 61, 316-320.

P. R. Pereira, J. Pires and M. B. de Carvalho, Langmuir, 1998, 14, 4584-4588.

A. Goj, D. S. Sholl, E. D. Akten and D. Kohen, J. Phys. Chem. B, 2002, 106, 8367-8375.

D. P. Serrano, G. Calleja, J. A. Botas and F. J. Gutierrez, Ind. Eng. Chem. Res., 2004, 43, 7010-7018.

W. P. Cheng, J. Z. Zhao and J. G. Yang, Catal. Commun., 2012, 23, 1-4. 
120

121

122

123

124

125

126

127

128

129

130

131

132

133

134

135

136

137

138

139

140

141

142

143

144

145

146

147

148

149
J. Pires, A. Carvalho and M. B. de Carvalho, Microporous Mesoporous Mater., 2001, 43, 277-287.

L. Zhou, Y. L. Chen, X. H. Zhang, F. M. Tian and Z. N. Zu, Mater. Lett., 2014, 119, 140-142.

B. Clausse, B. Garrot, C. Cornier, C. Paulin, M.-H. Simonot-Grange and F. Boutros, Microporous Mesoporous Mater., 1998, 25, 169-177.

J. Pires, A. Carvalho, P. Veloso and M. B. de Carvalho, J. Mater. Chem., 2002, 12, 3100-3104.

X. S. Zhao, Q. Ma and G. Q. Lu, Energy Fuels, 1998, 12, 1051-1054.

H. Yi, H. Deng, X. Tang, Q. Yu, X. Zhou and H. Liu, J. Hazard. Mater., 2012, 203-204, 111-117.

B. Levasseur, A. M. Ebrahim and T. J. Bandosz, Langmuir, 2011, 27, 9379-9386.

E. Ivanova and B. Koumanova, J. Hazard. Mater., 2009, 167, 306-312.

Y. Mathieu, M. Soulard, J. Patarin and M. Molière, Fuel Process. Technol., 2012, 99, 35-42.

M. Seredych, O. Mabayoje and T. J. Bandosz, Chem. Eng. J., 2013, 223, 442-453.

A. Srinivasan and M. W. Grutzeck, Environ. Sci. Technol., 1999, 33, 1464-1469.

Y. Zhi, Y. Zhou, W. Su, Y. Sun and L. Zhou, Ind. Eng. Chem. Res., 2011, 50, 8698-8702.

B. K. Marcus and W. E. Cormier, Chem. Eng. Prog., 1999, 95, 47-53.

R. T. Yang, R. Q. Long, J. Padin, A. Takahashi and T. Takahashi, Ind. Eng. Chem. Res., 1999, 38, 2726-2731.

M. M. Laboy, I. Santiago and G. E. López, Ind. Eng. Chem. Res., 1999, 38, 4938-4945.

L. S. Ferreira and J. O. Trierweiler, IFACProc. Vol., 2009, 7, 405-410.

Z. M. Wang, T. Arai and M. Kumagai, Energy \& Fuels, 1998, 12, 1055-1060.

P. A. Bingham and R. J. Hand, Mater. Res. Bull., 2008, 43, 1679-1693.

R. G. Anthony, R. G. Dosch, D. Gu and C. V Philip, Ind. Eng. Chem. Res., 1994, 33, 2702-2705.

C. W. Forsberg, Nucl. Technol., 2008, 131, 252-268.

T. S. Anirudhan, S. Rijith and A. R. Tharun, Colloids Surfaces A Physicochem. Eng. Asp., 2010, 368, 13-22.

M. R. Awual, S. Suzuki, T. Taguchi, H. Shiwaku, Y. Okamoto and T. Yaita, Chem. Eng. J., 2014, 242, 127-135.

J. Lento and R. Harjula, Solvent Extr. Ion Exch., 1987, 5, 343-352.

A. E. Osmanlioglu, J. Hazard. Mater., 2006, 137, 332-335.

S. P. Mishra and V. K. Singh, Appl. Radiat. Isot., 1998, 49, 43-48.

S. P. Mishra and D. Tiwary, Appl. Radiat. Isot., 1999, 51, 359-366.

D. J. Yang, Z. F. Zheng, H. Y. Zhu, H. W. Liu and X. P. Gao, Adv. Mater., 2008, 20, 2777-2781.

A. D. Ebner, J. A. Ritter and J. D. Navratil, Ind. Eng. Chem. Res., 2001, 40, 1615-1623.

I. Smičiklas, S. Dimovićand I. Plećaš, Appl. Clay Sci., 2007, 35, 139-144.

M. S. Gasser, G. A. Morad and H. F. Aly, J. Hazard. Mater., 2007, 142, 118-129. 
R. Cortés-Martínez, M. T. Olguín and M. Solache-Ríos, Desalination, 2010, 258, 164-170.

S. Xiaodong, Y. Sheng, W. Xuequan, T. Mingshu and Y. Liji, Cem. Concr. Res., 1994, 24, 133-138.

R. Arnek, I. Grenthe and A. Persson, Conditioning of Nuclear Power Wastes for Final Disposal: Use of Zeolites in Reactor Waste Treatment, 1979.

C. S. Griffith, V. Luca, F. Šebesta and P. Yee, Sep. Sci. Technol., 2005, 40, 1781-1796.

H. Mimura, K. Akiba and K. Kawamura, J. Nucl. Sci. Technol., 1994, 31, 463-469.

E. H. Borai, R. Harjula, L. malinen and A. Paajanen, J. Hazard. Mater., 2009, 172, 416-422.

B. T. Kim, H. K. Lee, H. Moon and K. J. Lee, Sep. Sci. Technol., 1995, 30, 3165-3182.

T. J. Tranter, T. A. Vereshchagina and V. Utgikar, Solvent Extr. Ion Exch., 2009, 27, 199-218.

K. A. Venkatesan, V. Sukumaran, M. P. Antony and T. G. Srinivasan, J. Radioanal. Nucl. Chem., 2009, 280, $129-136$.

D. E. Day, Z. Wu, C. S. Ray and P. Hrma, J. Non. Cryst. Solids, 1998, 241, 1-12.

B. C. Sales and L. A. Boatner, Science (80-. )., 1984, 226, 45-48.

M. G. Mesko and D. E. Day, J. Nucl. Mater., 1999, 273, 27-36.

E. A. Behrens, P. Sylvester and A. Clearfield, Environ. Sci. Technol., 1998, 32, 101-107.

M. J. Manos, N. Ding and M. G. Kanatzidis, Proc. Natl. Acad. Sci. U. S. A., 2008, 105, 3696-9.

P. Misaelides, A. Godelitsas, A. Filippidis, D. Charistos and I. Anousis, Sci. Total Environ., 1995, 173-174, $237-246$.

Z. Talip, M. Eral and Ü. Hiçsönmez, J. Environ. Radioact., 2009, 100, 139-143.

A. K. Kaygun and S. Akyil, J. Hazard. Mater., 2007, 147, 357-362.

S. M. Yu, C. L. Chen, P. P. Chang, T. T. Wang, S. S. Lu and X. K. Wang, Appl. Clay Sci., 2008, 38, 219-226.

D. L. Zhao, S. J. Feng, C. L. Chen, S. H. Chen, D. Xu and X. K. Wang, Appl. Clay Sci., 2008, 41, 17-23.

M. Metaxas, V. Kasselouri-Rigopoulou, P. Galiatsatou, C. Konstantopoulou and D. Oikonomou, J. Hazard. Mater., 2003, 97, 71-82.

L. M. Camacho, S. Deng and R. R. Parra, J. Hazard. Mater., 2010, 175, 393-398.

R. Han, W. Zou, Y. Wang and L. Zhu, J. Environ. Radioact., 2007, 93, 127-143.

A. Krestou, A. Xenidis and D. Panias, Miner. Eng., 2003, 16, 1363-1370.

A. M. El-Kamash, M. R. El-Naggar and M. I. El-Dessouky, J. Hazard. Mater., 2006, 136, 310-316.

T. Möller, R. Harjula and J. Lehto, Sep. Purif. Technol., 2002, 28, 13-23.

J. Lehto, L. Brodkin, R. Harjula and E. Tusa, Nucl. Technol., 1999, 127, 81-87.

A. Dyer, M. Pillinger, J. Newton, R. Harjula, T. Möller and S. Amin, Chem. Mater., 2000, 12, 3798-3804.

V. Luca, C. S. Griffith, E. Drabarek and H. Chronis, J. Nucl. Mater., 2006, 358, 139-150.

C. S. Griffith, F. Sebesta, J. V. Hanna, P. Yee, E. Drabarek, M. E. Smith and V. Luca, J. Nucl. Mater., 2006, 358, $151-163$.

V. Luca, E. Drabarek, H. Chronis and T. McLeod, J. Nucl. Mater., 2006, 358, 164-175. 
W. Xuequan, Y. Sheng, S. Xiaodong, T. Mingshu and Y. Liji, Cem. Concr. Res., 1991, 21, 16-20.

H. Mimura, J. Lehto and R. Harjula, J. Nucl. Sci. Technol., 1997, 34, 607-609.

T. Fukasawa, T. Nakamura, Y. Kondo and K. Funabashi, J. Power Energy Syst., 2008, 2, 67-72.

C. L. Crawford, J. C. Marra and N. E. Bibler, J. Alloys Compd., 2007, 444-445, 569-579.

P. Loiseau and D. Caurant, J. Nucl. Mater., 2010, 402, 38-54.

P. Loiseau, D. Caurant, N. Baffier, L. Mazerolles and C. Fillet, J. Nucl. Mater., 2004, 335, 14-32.

Y. Zhang, Z. Zhang, G. Thorogood and E. R. Vance, J. Nucl. Mater., 2013, 432, 545-547.

A. R. Boccaccini, E. Bernardo, L. Blain and D. N. Boccaccini, J. Nucl. Mater., 2004, 327, 148-158.

D. Caurant, O. Majerus, P. Loiseau, I. Bardez, N. Baffier and J. L. Dussossoy, J. Nucl. Mater., 2006, 354, $143-162$.

J. Dong, X. Wang, H. Xu, Q. Zhao and J. Li, Int. J. Hydrogen Energy, 2007, 32, 4998-5004.

T. Düren, L. Sarkisov, O. M. Yaghi and R. Q. Snurr, Langmuir, 2004, 20, 2683-2689.

M. M. K. Salem, P. Braeuer, M. v. Szombathely, M. Heuchel, P. Hartling, K. Quitzsch and M. Jaroniec, Langmuir, 1998, 7463, 3376-3389.

M. Heuchel, R. Q. Snurr and E. Buss, Langmuir, 1997, 13, 6795-6804.

A. Talesh, S. Siamak and S. Jalal, 2010, 29, 37-45.

M. Schweigkofler and R. Niessner, J. Hazard. Mater., 2001, 83, 183-196.

T. Montanari, E. Finocchio, I. Bozzano, G. Garuti, A. Giordano, C. Pistarino and G. Busca, Chem. Eng. J., 2010, 165, 859863.

E. Beerdsen, B. Smit and S. Calero, J. Phys. Chem. B, 2002, 106, 10659-10667.

M. Sakizci, J. Therm. Anal. Calorim., 2015, 122, 611-620.

M. Sakizci and L. Özgül Tanriverdi, Turkish J. Chem., 2015, 39, 970-983.

E. Finocchio, G. Garuti, M. Baldi and G. Busca, Chemosphere, 2008, 72, 1659-1663.

S. Sircar, Sep. Sci. Technol., 1988, 23, 519-529.

P. Bénard and R. Chahine, Langmuir, 1997, 13, 808-813.

K. Azizi, K. Salabat and A. Seif, Appl. Surf. Sci., 2014, 309, 54-61.

P. Cosoli, M. Ferrone, S. Pricl and M. Fermeglia, Chem. Eng. J., 2008, 145, 93-99.

M. C. Mitchell, J. D. Autry and T. M. Nenoff, Mol. Phys., 2001, 99, 1831-1837.

M. C. Mitchell, M. Gallo and T. M. Nenoff, J. Chem. Phys., 2004, 121, 1910-1916.

L. Schlapbach and A. Züttel, Nature, 2001, 414, 353-358.

R. Biniwale, S. Rayalu, S. Devotta and M. Ichikawa, Int. J. Hydrogen Energy, 2008, 33, 360-365.

J. Wolf, Vacuum, 2003, 684-687.

R. Prins, Chem. Rev., 2012, 112, 2714-2738. 
211 L. Wang and R. T. Yang, Catal. Rev., 2010, 52, 411-461.

212 X. Z. Chu, Y. P. Zhou, Y. Z. Zhang, W. Su, Y. Sun and L. Zhou, J. Phys. Chem. B, 2006, 110, 22596-22600.

213 H. W. Langmi, D. Book, A. Walton, S. R. Johnson, M. M. Al-Mamouri, J. D. Speight, P. P. Edwards, I. R. Harris and P. A. Anderson, J. Alloys Compd., 2005, 404-406, 637-642. Anderson and I. R. Harris, J. Alloys Compd., 2003, 356-357, 710-715.

W. P. Kalisvaart, C. T. Harrower, J. Haagsma, B. Zahiri, E. J. Luber, C. Ophus, E. Poirier, H. Fritzsche and D. Mitlin, Int. J. Hydrogen Energy, 2010, 35, 2091-2103. 619-623. 515-520.

228 C. Weidenthaler, A. Pommerin, M. Felderhoff, W. Sun, C. Wolverton, B. Bogdanović and F. Schüth, J. Am. Chem. Soc., 2009, 131, 16735-16743. 
Table of Contents Graphic

A review of the use of inorganic materials as host media for the storage of various wastes and alternative fuels.

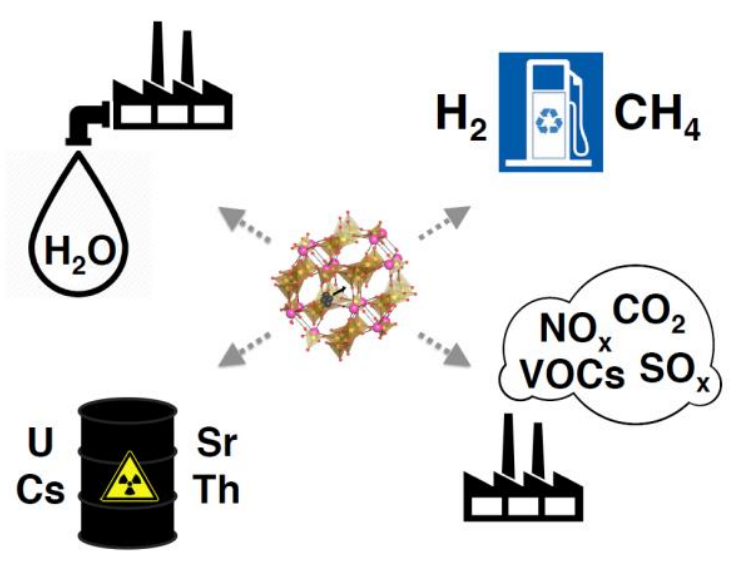

